\title{
Innovative pulses for European temperate regions: a review
}

\author{
Alicia Ayerdi Gotor ${ }^{1 *}$ and Elisa Marraccini ${ }^{2,3}$ \\ 1 UniLaSalle Beauvais, AGHYLE, UP 2018.C101, Beauvais, SFR Condorcet FR CNRS 3417, France, ali- \\ cia.ayerdi-gotor@unilasalle.fr \\ 2 UniLaSalle Beauvais, INTERACT, UP 2018.C102, Beauvais, SFR Condorcet FR CNRS 3417, France, \\ 3 Department of Agricultural, Food, Environmental and Animal Sciences, University of Udine, Italy, \\ elisa.marraccini@uniud.it \\ * Correspondence: Alicia.ayerdi-gotor@unilasalle.fr; Tel.: (+33(3)44062549) AAG
}

\begin{abstract}
In the Global North, there is an increasing interest in pulses both for their beneficial effects in cropping systems and for human health. However, despite these advantages, the acreage dedicated to pulses has been declining and their diversity reduced, particularly in European temperate regions, due to several social and economic factors. This decline has stimulated a political debate in the EU on the development of plant proteins. By contrast, in the Global South, a large panel of minor pulses is still cropped in regional patterns of production and consumption. The aim of this paper is to investigate the for cultivation of potential minor pulses in European temperate regions as a complement to common pulses. Our assumption is that some of these crops could adapt to different pedo-climatic conditions, given their physiological adaptation capacity, and that these pulses might be of interest for the development of innovative local food chains in an EU policy context targeting protein autonomy. The research is based on a systematic review of 269 papers retrieved in the Scopus database (1974-2019), which allowed us to identify 41 pulses as candidate species with a protein content higher than $20 \%$ that are already consumed as food. For each species, the main agronomic (e.g. temperature or water requirements) and nutritional characteristics (e.g. proteins or antinutritional contents) were identified in their growing regions. Following their agronomic characteristics, the candidate crops were confronted with variability in the annual growing conditions for spring crops in European temperate areas to determine the earliest potential sowing and latest harvest dates. Subsequently, the potential sum of temperatures was calculated with the Agri4cast database to establish the potential climatic suitability. For the first time, 21 minor pulses were selected to be grown in these temperate areas and appear worthy of investigation in terms of yield potential, nutritional characteristics or best management practices.
\end{abstract}

Keywords: Grain legumes; crop diversification; sustainable intensification; Growing Degree Days

\section{Introduction}

There is an increasing debate about the importance of plant-based proteins and the diversification of protein sources for food or feed [1]. Plant-based proteins originate in several botanical families but are mainly concentrated in legumes. Despite the importance of grain legume, their production and consumption are declining worldwide $[2,3]$ whereas the acreage dedicated to soybean is continuously increasing due to the intensification of livestock production [4]. Although grain legume diversity is very high from a worldwide perspective [5], these species often have local patterns of production and consumption in several developed and developing countries [6]. Worldwide grain legumes production increased by $15 \%$ between 2016 and 2017. This increase in production occurred in each continent, except America where production remained stable. Soybean production also increased during this period. This increase was mainly due to the largest producers North and South America. Based on the most recent available FAOSTAT data [7], there are four main pulses cultivated worldwide. Beans (all Phaseolus species included) were 
the most produced in 2019 (Table 1), half of which were produced in Asia. Peas are produced in Europe and in North America; however, 83\% of chickpeas production (including the species Cicer arietinum) was harvested in Asia. Beyond these four common grain legumes, cowpea production reached 8.9 million tons, but was concentrated in Africa (97\%) and pigeon pea production, which attained 4.4 million tons concentrated in Africa (15\%) and Asia (83\%). Broad beans (including Vicia faba, horse bean, broad bean and field bean) were also largely cultivated in 2019 with more than 5.4 million tons harvested. Lupins were produced mainly in Oceania (47\%) and Europe (37\%). Vetches with a production of 0.9 million tons were produced in Europe (31\%) and Africa (43\%) and Bambara bean was only cultivated in Africa with an annual production of 0.2 million tons. The other pulses, grouped together for statistical purposes, accounted for 4.5 million tons worldwide. The only six pulses that are exchanged internationally are, in decreasing order of importation quantity, peas, with $37.6 \%$ of all world imports, representing 6.5 million, beans with $21 \%$, lentils with $17 \%$, chickpeas $11 \%$, broad beans with $5 \%$ and Bambara beans with only $0.01 \%$ according to the FAO data on 2016 market exchanges.

Table 1: World production of pulses in tonnes (T) and contribution percentage (\%) of each continent (Faostat 2019)

\begin{tabular}{ccccccc}
\hline & World (T) & Africa (\%) & America (\%) & Asia (\%) & Europe (\%) & Oceania (\%) \\
\hline Bambara beans & 228920 & 100.0 & 0.0 & 0.0 & 0.0 & 0.0 \\
Beans, dry & $28,902,672$ & 24.4 & 24.4 & 49.7 & 1.3 & 0.3 \\
Broad beans, horse beans, & & & & & & \\
dry & $5,431,503$ & 27.0 & 4.0 & 33.6 & 29.4 & 6.0 \\
Chick peas & $14,246,295$ & 4.9 & 6.1 & 83.4 & 3.6 & 2.0 \\
Cow peas, dry & $8,903,329$ & 96.8 & 0.7 & 2.2 & 0.3 & 0.0 \\
Lentils & $5,734,201$ & 3.3 & 42.7 & 42.5 & 2.2 & 9.3 \\
Lupins & $1,006,842$ & 7.5 & 6.3 & 0.0 & 39.0 & 47.1 \\
Peas, dry & $14,184,249$ & 3.9 & 39.3 & 18.1 & 37.0 & 1.7 \\
Pigeon peas & $4,425,969$ & 15.1 & 1.8 & 83.2 & 0.0 & 0.0 \\
Pulses others & $4,553,029$ & 31.5 & 0.9 & 45.3 & 22.0 & 0.3 \\
Vetches & 762,795 & 42.6 & 12.7 & 12.4 & 31.4 & 0.9 \\
Pulses, Total & $88,379,804$ & 24.1 & 18.7 & 44.3 & 10.8 & 2.2 \\
\hline
\end{tabular}

Minor pulses are produced and consumed locally worldwide, and there is no exchange between countries unless they are already cultivating and consuming these minor pulses [8]. This is more a consequence of food habits than because of pedoclimatic nor agronomic constraints.

In 2018 in Europe, only 1.3\% of the cultivated acreage was dedicated to pulses (Eurostat) where peas covered $37 \%$ of the surface followed by broad beans, field beans $(26 \%)$ and sweet lupins $(6 \%)$. The rest $(26.4 \%)$ came from other dry pulses such as lentils, chickpeas and beans (Eurostat).

However, the production of pulses has decreased during the last five decades [9]. Several factors have driven this decrease. First, the reduction of human consumption of vegetal proteins was negatively correlated to the increase in the standard of living of the population and the substitution by animal proteins [10]. Besides, less time is devoted to cooking, which is essential to reduce the impact of anti-nutritional factors of pulses, leading to a reduced consumption [11]. Second, the increasing import of cheap soybean meal to feed livestock from North and South America (2017) induced a reduction in the price of meat. The availability inexpensive proteins has supported the intensification of livestock production which, at the same time, has dissociated livestock breeding from crop production for feeding [12]. The separation of protein and livestock productions led to an 
intensification and a reduction of the number of cultivated crops, chosen for their economical performances. Moreover, as Watson et al. [9] argued, the yield increase of cereals in Europe since the 70s was not followed by a similar yield increase of protein crops, leading to an expansion of cereal acreage while protein crops remained less attractive for farmers. However, since 2015 this trend has ended in Europe probably because of both the increase in organic farming and the different policy instruments supporting protein crops [13].

European farmers, particularly those in arable systems look to diversify the crop rotations to more sustainable and resilient cropping systems [14]. One of the major groups of crops targeted for diversification is grain legumes [14,15]. Several scholars have been interested in grain legumes because of their potential uses for food, feed and bioenergy/biomaterials but also because of the agro-ecosystem services they provide [2,4]. However, there is a general lack of knowledge and references regarding these grain legumes in terms of production potential in Northern countries and also about the diversity of their possible usage. Moreover, some scholars argue that the low adoption by European farmers of grain legumes compared with other crops is caused by low productivity and low profit margins, technological lock-in, and a low temporal yield stability [16-18]. Reckling et al. [19] have underlined that in Northern Europe, the grain legume yield is as stable that of other major spring crops e.g. spring cereals or rape seed. Yield stability is also enhanced in the other crops of the cropping system by grain legumes, as demonstrated by Petrova Chimonyo et al. [20] in maize-based cropping systems. Mawois et al. [21] have studied the trajectories of farms that increased the proportion of grain legumes in their crop rotations, highlighting three levels for their successful introduction: the stability of the supply (both as onfarm consumption and in the food supply chain), the benefits of grain legumes as the preceding crop and/or the involvement of farmers in peer' groups.

In this context, the increase in the use of grain legumes in European cropping systems can rely on two strategies. The first is to increase the current rate of cultivation of common pulses, e.g. lentils, chickpeas and common beans, in these countries, attempting to overcome the problems of lock-in at the supply chain level. This is the strategy that is currently analysed in the mainstream literature regarding European temperate regions and in some European research and innovation projects, e.g. PROTEIN2FOOD or LEGVALUE. A complementary strategy could be to provide alternatives in the panel of grain legumes potentially cropped or processed by identifying new species from worldwide grain legume biodiversity and creating new niches for these species and a renewed interested in grain legumes. This strategy can rely on the one hand, on the adaptability of grain legumes to new environmental conditions $[\mathbf{2 2}, \mathbf{2 3}]$ and on the other hand, on the interest of the supply chain in new plant-based products, as occurred in the case of quinoa $[24,25]$. In this paper, our goal is to explore the latter strategy. Information on tropical grain legumes or minor pulses already exists in literature, however it is often limited either to one species [26,27] or to a comparison of several species on a national/continental level, e.g. in India [28-30], Australia [31], Africa [32-34], or to a comparison of wild species [26,35,36]. The aim of this review is twofold: on the one hand, it will provide insights about the agronomical and nutritional characteristics of a large panel of grain legume crops which are currently unknown and cultivated poorly or not at all in European temperate regions and on the other hand, it will explore the potential matching of these pulses in temperate European climatic conditions. As we are interested in grain legumes as food, in this paper we will use the terms 'pulses' and 'grain legumes' as synonyms and distinguish them when the legume destination is not intended as food.

The paper will be organized as follows: in the materials and methods section the first part will present a systematic review and the different variables considered for each species and the second part will describe how the main climatic characteristics of European temperate region were extracted from the Agri4cast database. In the results section we will summarize the main agronomic and nutritional (or antinutritional) characteristics of a set 
of pulses and some candidate species to be grown in temperate conditions, additional material are provided in Appendices A to D. In the discussion and conclusion section, we will discuss both the barriers to the introduction of these crops and the research and development needed to better evaluate their potential in European temperate regions.

\section{Materials and Methods}

\subsection{Literature review and data collection}

A systematic literature review was performed according to the 7 steps method formalized by the Centre for Evidence Based Conservation [37]. The method adopted for this study is illustrated in Figure 2. The first step was the identification of the research question. We wondered about the global diversity of protein-based crops, namely of pulses, that could support a crop diversification in European temperate regions. To answer this question, we looked for a general overview of worldwide pulses diversity and characteristics. To this end, we firstly carried out a general literature survey in the Scopus database according to the Scopus reference Guide [38] by selecting the advanced searches TITLEABS-KEY ((pulses AND 'grain legumes') AND crops) AND PUBYEAR > 1974 AND PUBYEAR < 2020 AND DOCTYPE (re) AND LANGUAGE (English) AND SUBJAREA (agri)) in the title, abstract and keywords with a focus on review articles, in the 1974-2019 time span in the Biological Sciences sub-database. We obtained a preliminary list of 231 reviews. Based on these reviews, we compiled a list of species to be checked. The eligibility criteria were to be cropped (not wild), used for human consumption and having a protein content in the grain equal or superior to 20. The species identified were double checked through a complementary search in three international databases: FoodData Central from the United State Department of Agriculture (formerly USDA National Nutrient Database for Standard Reference), Prota4U hosted by Wageningen University, and the International Network of Food Data System from FAO. A list of 47 species (common and scientific names) was finally established (Table 2). At this stage, since the information collected was too general on the agronomic and nutritional characteristics of grain legumes, we performed in a second step an in-depth literature review on the 47 previously selected species (Table 1). This second review was also performed in the Scopus database, focusing on scientific articles (therefore excluding reviews), in the 1974-2019 time span in the Biological Sciences sub-database. A grouped search including all the species was also performed in order to build a common database of minor pulses and deleting duplicates. We considered minor and major pulses as separate searches. 


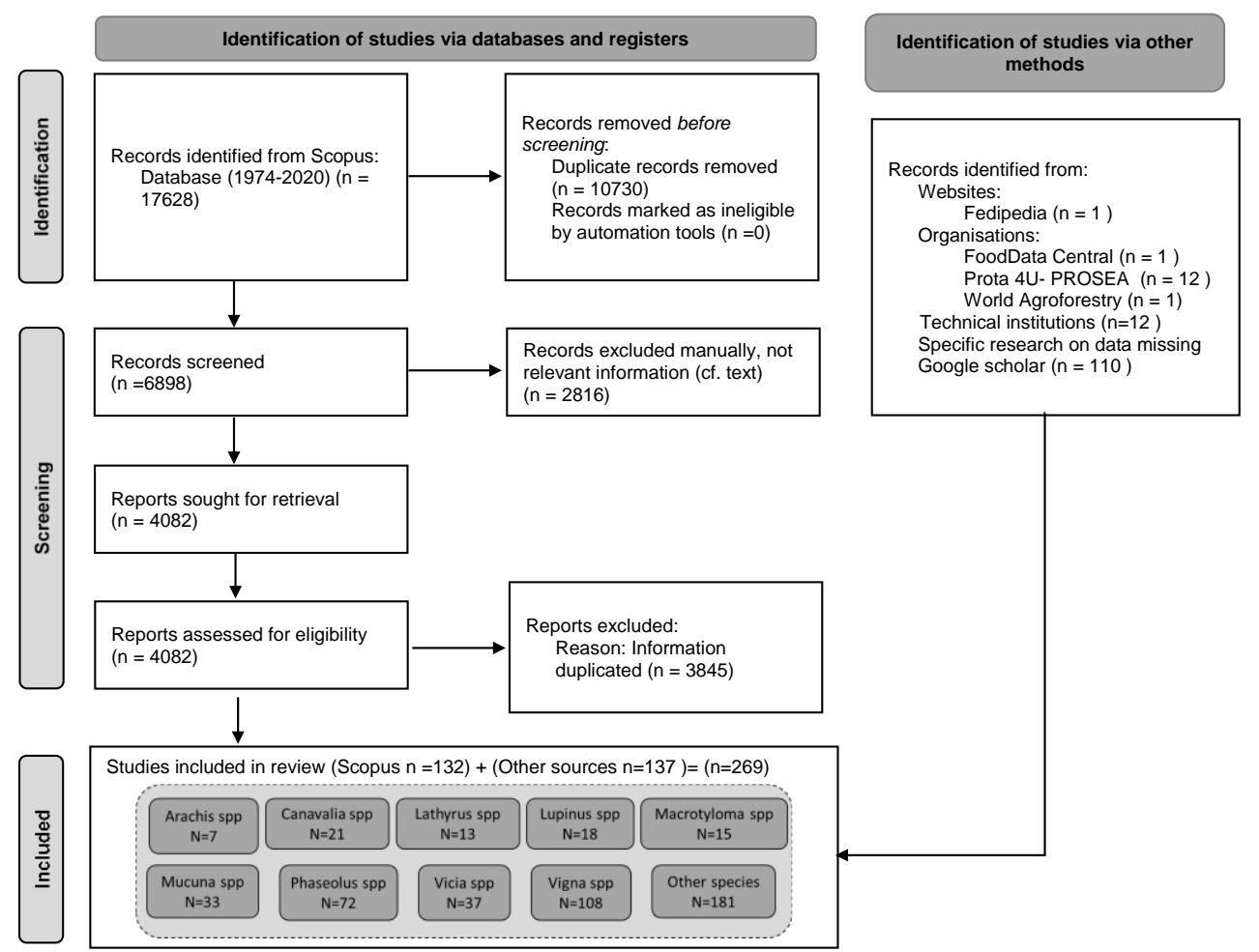

Figure 1: PRISMA 2020 flow diagram systematic review on pulses [39]. Details on the species included as well as on the number of papers retrieved are provided in Table 1.

Example of the Boolean string for this second search for one species is TITLE-ABSKEY ((ervil OR 'Vicia ervilia' OR 'Bitter vetch') AND crop*) AND PUBYEAR > 1974 AND PUBYEAR < 2020 AND DOCTYPE (ar) AND LANGUAGE (English) AND SUBJAREA (agri) AND NOT ('cover crop*' OR 'green manure' OR intercrop*). By selecting the subject area 'AGRI' we tried to avoid the number of papers in ecology or natural sciences focusing on medical or beneficial properties of some of these species. Moreover, limiting the search to 'crop' helped us to select those papers that refers to cultivated species (not wild) and grouping both the common(s) and scientific names guaranteed to catch a maximum of the papers referring to a specie. Finally, after a preliminary analysis of the database, we identified several papers dealing with the use of minor pulses as cover crops or green manure, along with their use in intercropping. As we were not interested in these topics, we excluded the papers including such words in the abstract, title or keywords. Even though we are aware that searching among the English literature limited the number of papers, we believed that this choice could ensure a common standard among the selected papers.

Table 2 Retrieved papers in the Scopus database for the period 1974-2019 for a sample of cultivated minor and major pulses (in grey) with a protein seed content above $20 \%$, individual researches. In grey, a comparison with the same search repeated for major pulses.

\begin{tabular}{cccc}
\hline Common name & Other names & Scientific name & $\begin{array}{c}\text { Retrieved papers in the } \\
\text { Scopus database (1974- } \\
\text { 2019) }\end{array}$ \\
\hline Acacia leucophloea & & 4 & 102 \\
Adzuki bean & Azuki bean, aduki bean & Vachellia leucophloea & Vigna angularis \\
African locust bean & & Parkia biglobosa & 31 \\
\hline
\end{tabular}




\begin{tabular}{|c|c|c|c|}
\hline African nut bean & & Ricinodendron heudelotti & 1 \\
\hline African oil bean & & Pentaclethra macrophylla & 5 \\
\hline African yam bean & & Sphenostylis stenocarpa & 27 \\
\hline Bambara groundnut & Earth pea & Vigna subterranea & 99 \\
\hline Butterfly pea & & Centrosema pubescens & 16 \\
\hline Cowpea & Black eye bean, black eye pea & Vigna unguiculata & 1,348 \\
\hline Ervil & Bitter vetch & Vicia ervilia & 40 \\
\hline Fenugreek & & Trigonela foenum-graecum & 145 \\
\hline Grass pea & & Lathyrus sativus & 131 \\
\hline Guanacaste & & Enterolobium cyclocarpum & 11 \\
\hline Horsegram & & Macrotyloma uniflorum & 43 \\
\hline Housa groundnut & Hausa groundnut, Kersting groundnut & Macrotyloma geocarpum & 6 \\
\hline Itching bean & & Mucuna pruriens var. pruriens & 1 \\
\hline Jack bean & & Canavalia ensiformis & 36 \\
\hline Kedaung & Tree bean & Parkia roxburghii & 2 \\
\hline Kidney bean & & Phaseolus vulgaris & 131 \\
\hline Lablab & Hyacint bean & Lablab purpureus & 125 \\
\hline Lima bean & $\begin{array}{c}\text { Butter bean, Java bean, Madagascar } \\
\text { bean, sugar bean }\end{array}$ & Phaseolus lunatus & 113 \\
\hline Marama bean & Morama bean & Tylosema esculentum & 8 \\
\hline Moth bean & Mat bean, Turkish gram & Vigna aconitifolia & 63 \\
\hline Mung bean & $\begin{array}{l}\text { Golden gram, green gram, Moong } \\
\text { bean }\end{array}$ & Vigna radiata & 811 \\
\hline Navy bean & Pearl haricot, haricot bean & Phaseolus vulgaris & 66 \\
\hline Narbon bean & Narbon vetch & Vicia Narbonensis & 43 \\
\hline Pigeon pea ${ }^{\mathrm{n}}$ & Red gram & Cajanus cajan & 590 \\
\hline Pinto bean & & Phaseolus vulgaris & 58 \\
\hline Pinto peanut & & Arachis pintoi & 70 \\
\hline Purple mucuna & & Mucuna atropurpurea & 0 \\
\hline Red moneywort & & Alysicarpus rugosus & 1 \\
\hline Rice bean & & Vigna umbellata & 55 \\
\hline Scarlet runner bean ${ }^{\circ}$ & Runner bean & Phaseolus coccineus & 18 \\
\hline Sesban & & Sesbania sesban & 46 \\
\hline Sword bean & & Canavalia gladiata & 9 \\
\hline Tamarind & & Tamarindus indica & 45 \\
\hline Tarwi & & Lupinus mutabilis & 30 \\
\hline Tepary bean & & Phaseolus acutifolius & 46 \\
\hline Urad & Black bean, black lentil, mungo bean & Vigna mungo & 357 \\
\hline Velvet bean & Cowitch & Mucuna pruriens var. utilis & 25 \\
\hline Winged bean & & Psophocarpus tetragonolobus & 39 \\
\hline Yam bean & & Pachyrhizus erosus & 45 \\
\hline Broad bean & Faba bean, horse bean & Vicia faba & 918 \\
\hline Chickpea & Bengal gram & Cicer arietinum & 1795 \\
\hline Common bean & $\begin{array}{l}\text { Field bean, bell bean, English bean, } \\
\text { Windsor bean, pigeon bean }\end{array}$ & Phaseolus vulgaris & 1988 \\
\hline Field pea & & Pisum sativum & 2014 \\
\hline Lentil & & Lens culinaris & 901 \\
\hline Lupin & & Lupinus spp. & 688 \\
\hline
\end{tabular}

Then, a second search was performed in Google Scholar according to the same criteria as in the Scopus database in the case of absent or insufficient number of papers (e.g. Purple mucuna or Red moneywort), or in cases where the papers retrieved in the Scopus database did not target our goal e.g. focusing exclusively on genetics, crop protection or 
agroforestry potential or looking only for a specific characteristic in growth, agronomy, nutritional or anti-nutritional composition. For minor pulses with a limited or local use, nutritional characteristics were obtained from research articles, of which a mean was calculated (protein, oil, carbohydrates and fibre content) or an interval was indicated.

The papers obtained from the Scopus searches for each pulse species were stored in a Zotero database, which contained a total of 17628 articles and 10730 of them were discarded as duplicates. Among the duplicates, there were often papers comparing two or several pulses. An exhaustive screening on titles was performed in order to eliminate outof-scope papers that did not provide useful information for our research (6661 papers). The most common reasons for deleting a paper from the list were the following: the name of a pulse was mentioned only as a comparison of one characteristic to another crop [40], the trial or analysis was performed in intercropping, thus evaluating the impact of the cover crop on the staple food yield [41], or there was no relation to the topic, e.g. papers dealing with biochemical [42] or genetic characteristics [43] or the use of pulse extracts as green fertilizers [44] or seed treatments [45] without any relation to pulse yield or seed quality. Papers with an historical or archaeobotanical approach [46] and those stating consumer preferences [47] or the impact of the feed on the animal's health [48] were also excluded. For some crops such as cowpea, or Bambara bean not all the articles found are cited in the present review, as for one topic such as resistance to a fungus or an insect dozens of articles could be found. Some cultivated legumes showed an interesting seed composition but they are not used as food. Brebra seed (Millettia ferruginea) was excluded from our analyses, even though the seed is edible. Other species from Lathyrus and Vicia with a protein content above $20 \%$ were used as food but are either no longer cultivated [49] or are cultivated on a few hectares of a single Greek Island for traditional dishes like Lathyrus clymenum [50]. Finally, papers dealing with consumers preferences for different varieties or for different cooking techniques were also excluded.

In the end, the final number of papers used for the review was 269.

\subsection{Bibliographic corpus analysis}

The file containing the Scopus extraction with information from 4082 documents assessed for eligibility was first analysed to describe the papers in terms of sources (journals), years of publications and origin. For these analyses, we calculated the absolute, relative and cumulative frequencies. Then, the corpus was uploaded and analysed using the CorTexT platform, already used for agronomic literature reviews [51,52], throughout the CorTexT Manager (http://manager.cortext.net/).

A term-extraction algorithm was first performed using the title, abstract and keywords of each document to identify the 100 most cited terms. With those terms several functions have been tested in the default proposed form such as the contingency matrix, geospatial exploration and the network mapping to see the relationships between species, countries, journals and other agronomical terms.

\subsection{Descriptive analysis}

The aim of the descriptive analysis was to characterize both the agronomic and nutritional characteristics of the selected species. Both are essential to select candidate species diversifying cropping systems in temperate regions to be used in the food industry. On the one hand, for the agronomic characteristics, we analysed the environmental requirements (optimal, minimal and maximal temperature, average water requirement, duration of crop cycle), fertilizer inputs, potential yield, fixed nitrogen and symbiotic bacteria. On the other hand, for the nutritional characteristics, we analysed the nutritional profile (calories, protein content, carbohydrates, vitamins, minerals, micro-nutrients) and the most common antinutritional characteristics (phytic acid, total tannins, saponins, trypsin inhibitors, lectins and other antinutritional molecules). 


\subsection{Species selection for temperate regions}

The most promising crops for arable systems in temperate regions were selected from the database mainly according to the environmental requirements. Focusing on arable systems, only annual crops that could rotate with other crops were considered. For a preliminary evaluation, we also excluded crops that require special harvesting techniques such as those that produce grains underground. For annual species we considered those having varieties with a maximum crop duration of 120 days, thus corresponding to summer crops in temperate regions. We also excluded species with optimal temperatures higher than $25^{\circ} \mathrm{C}$ or where those data were absent. We hypothesize for the annual crops a growing period from 1 March to 15 October. We could not consider the crop heat units to reach maturity, the sensitivity to day length and the precocity because of a lack of data in the literature. We considered as candidate species those that can potentially grow in continental European temperate regions under oceanic influence (by excluding temperate areas in Ireland) according to the European environmental stratification proposed by Metzger et al. [53]. Climatic data (1998-2018) were extracted on the Agri4cast database provided by the European Joint Research Centre (https://agri4cast.jrc.ec.europa.eu/DataPortal/Index.aspx) in the area between Latitudes $47.56^{\circ}$ to $53.44^{\circ}$ and Longitudes $-0.017^{\circ}$ to $7.28^{\circ}$. The spring sowing date (date to start accumulating Growing Degree Days [GDD]) was considered as the last of three consecutive days with daily mean air temperatures equal to or greater than $12.8^{\circ} \mathrm{C}$ based on the Corn Heat Units Index used to characterize climatic regions [54]. The potential season-ending date (date to stop accumulating GDD) was considered as the earliest date when the daily mean air temperature dropped to $12{ }^{\circ} \mathrm{C}$, excluding dates included in the 90 days following the sowing date. The sum of temperatures was calculated within those dates considering base temperatures of $6^{\circ} \mathrm{C}$ and $10^{\circ} \mathrm{C}$. Given the lack of data on the grain legumes investigated, those climatic data were compared to the requirements of already cultivated spring crops such as corn or soybean, to establish a preliminary conformity of the criteria.

\section{Results and discussions}

\subsection{Descriptive analysis of the bibliographic corpus}

The selected corpus on pulses was composed of 4081 documents. More than $50 \%$ of the research was published since 2010 (data not shown). The observed bibliography shows that the interest in pulses has been increasing especially the last 15 years reaching more than 250 documents per year (data not shown). An analysis of the country of origin of the first authors show that affiliations from 116 countries are represented, of them more than $50 \%$ are from two countries, Brazil and India. Figure 2 shows the countries of origin of the first authors of $75 \%$ of the articles, and papers from European temperate areas are poorly represented. Finally, more than 600 individual journals are represented in the corpus, and 55 account for $50 \%$ of the articles. Of these latter journals, mostly are in the Agronomy and crop science area, e.g. Crop Science, Field Crop Research or Experimental Agriculture, and have a partially a regional coverage, e.g. Indian Journal of Agricultural Sciences or the Australian Journal of Crop Science (data not shown). The matrix of contingence obtained from the CorTexT platform (data not shown) also confirmed that almost $40 \%$ of the retrieved papers were published in two Indian Journals (Indian Journal of Agricultural Sciences and Indian Journal of Agronomy) and more than $40 \%$ on Phaseolus vulgaris (or common bean, data not shown). This was confirmed by the geospatial exploration which identified India as the main producer of references on pulses, ahead of for the other countries in the world. 


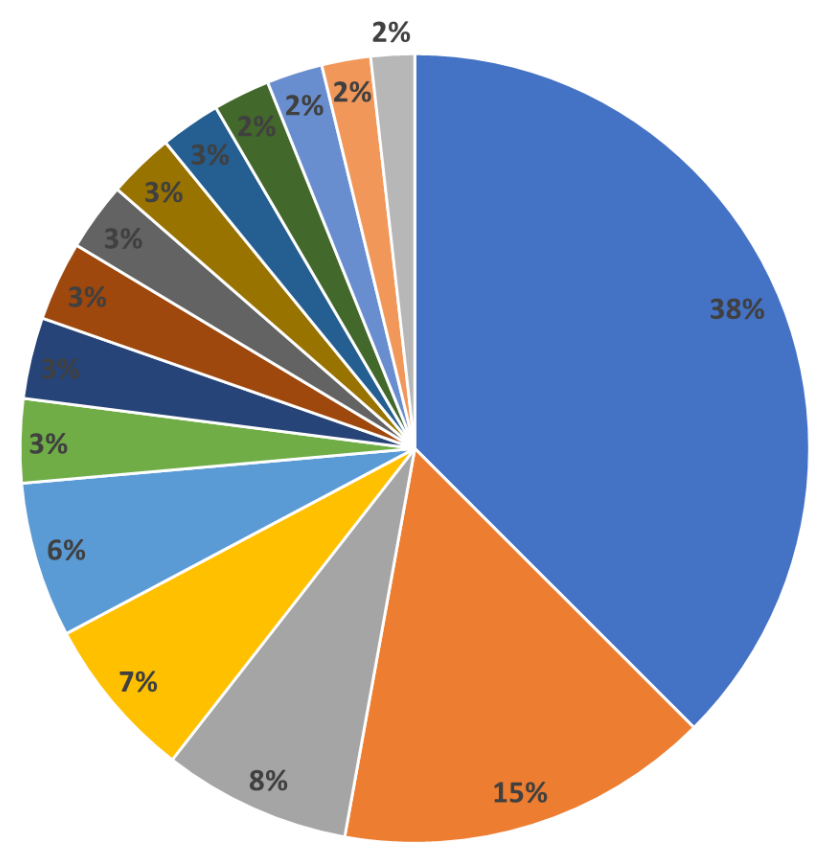

- India
- Brazil
- Nigeria
n United States
- Canada
- Pakistan
- Japan
- United Kingdom
- Mexico
- South Africa
- Spain
- Colombia
- China
- Iran

Figure 2: Country of origin of the first author (affiliation) in the first $25 \%$ cumulated frequency of the 4082 papers assessed for eligibility

The most cited terms were Phaseolus vulgaris (in different written forms) with 537 occurrences which corresponded to more than $25 \%$ of all the literature, followed by Vigna radiata 407, Cajanus Cajan 238, Experimental field 155, Triticum aestivum 152, Vigna mungo 142, Common bean 95, Pisum sativum 70 and Arachis hypogaea 69. Sowing the large disparity that exists between main pulses and minor pulses in the litterature. Those terms are also entered into evidence on the network map of the 100 most cited terms in the abstract (Figure 3). We can also identify other terms associated with the yield (height of the plant, seeds dry weight or leaf area), management practices (P fertilization) associated with the impact on other crops (like wheat or mustard) or on the pulse studied and resistance to biotic or abiotic stresses (drought, moisture, weeds, diseases and insects). 


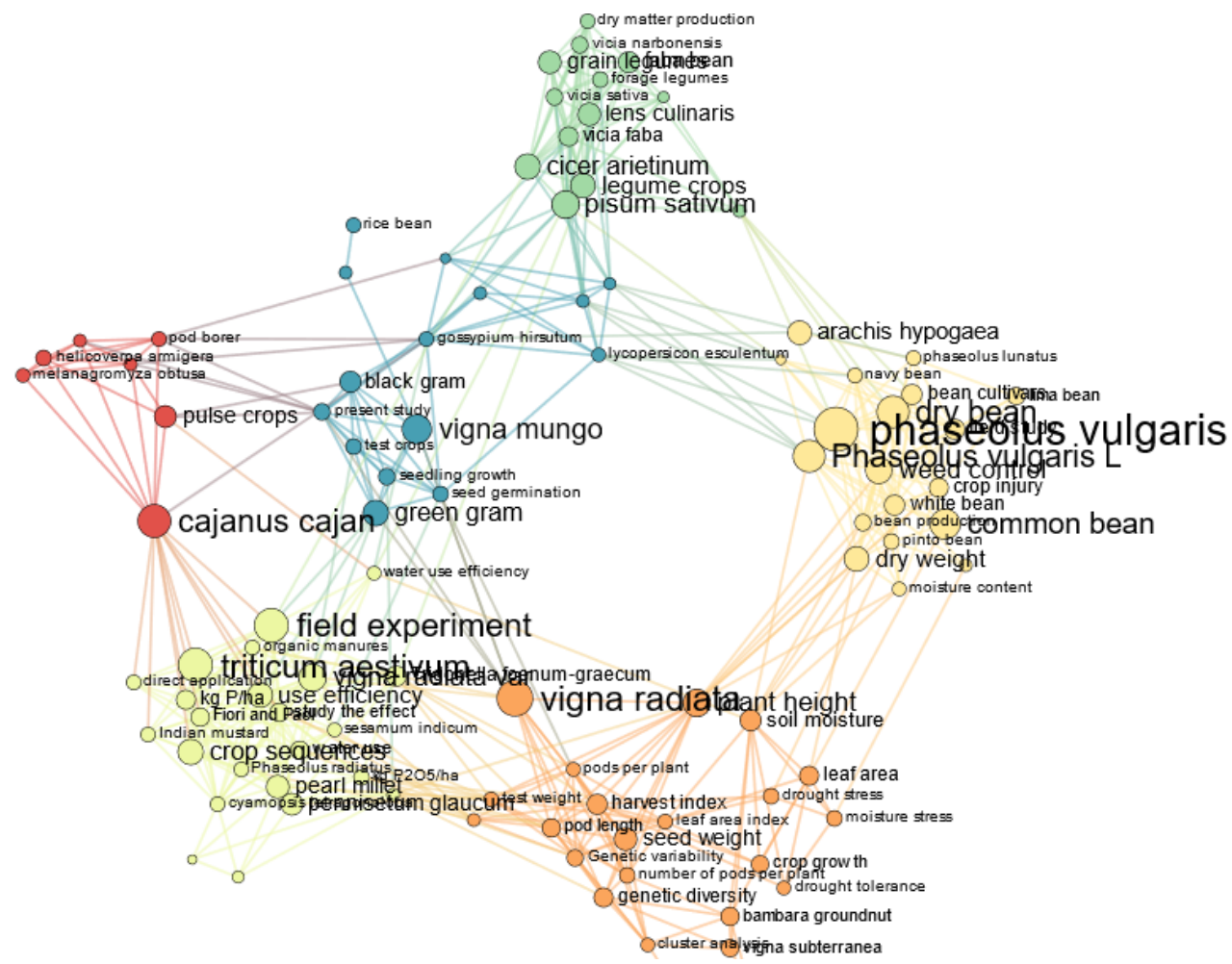

Figure 3: CorTexT Manager - script Network Mapping. The size of the dots reflects the occurrence frequency: the larger the dot, the higher the occurrence. Analysis was performed on the 4082 documents identified in Scopus based on the 100 most recurrent terms.

These data also confirm the existing gaps in knowledge and research interests between the common bean, pea, other major pulses like cowpea, mung bean or urad and the others minor pulses.

\subsection{Types of pulses and agronomical needs}

Pulses are found worldwide, and some of them are adapted to temperate climates (kidney bean, lupins) (Table 3, Appendix A) whilst a larger number can be found in tropical or subtropical areas (adzuki bean, cowpea) and a few can be found in both areas (soybean, broad beans). Crops such as the common bean that can grow under both temperate and tropical climate conditions are grown during spring-summer period and in cold (winter) periods in temperate areas, or at high altitudes in tropical areas [53-55]. In soybean, on the other hand, several maturity groups adapted to different pedoclimatic conditions have been developed [56,57]. Most of them have a crop length between 2 and 6 months, but it is highly variable even within a species. However, those crop lengths have been observed in tropical conditions allowing a high GDD and the exact GDD is not precisely defined in the literature. Some crops have longer cycles that can reach nearly a year (i.e. cowpea and sword bean [58]), and others can be cultivated as an annual plant (i.e. urad, tepary bean [59]) or as a perennial (i.e. pigeon pea [60], morama bean, Mucuna atropurpurea [58], and yam bean [61]). The perennial pulses could also be cultivated as annuals depending on the agronomical practices of the country. Despite the in-depth research conducted it was difficult to identify the intra species genetic diversity available that may be conductive to a larger potential for one species to spread to other climatic conditions or agronomical practices.

\begin{tabular}{cccccc}
\hline $\begin{array}{c}\text { Pulses - Common } \\
\text { name }\end{array}$ & $\begin{array}{c}\text { Temperature }\left({ }^{\circ} \mathrm{C}\right) \\
\text { Min; Max; Optimal }\end{array}$ & $\begin{array}{c}\text { Crop } \\
\text { length }\end{array}$ & $\begin{array}{c}\text { Water requirements } \\
(\mathbf{m m})\end{array}$ & $\begin{array}{c}\text { Yield } \\
(\mathbf{t} / \mathbf{H a})\end{array}$ & $\begin{array}{c}\mathrm{Kg} \mathrm{N} \text { fixed } \\
(\mathbf{k g} / \mathbf{h a})\end{array}$ \\
\hline Adzuki bean & $5-10 ; 34 ; 15-30$ & $\begin{array}{c}60- \\
190 \mathrm{~d}\end{array}$ & $500-1700$ & $0.5-3.5$ & 100 \\
\hline
\end{tabular}




\begin{tabular}{|c|c|c|c|c|c|}
\hline Butterfly pea & $5 ; 35 ; 20-28$ & $\begin{array}{l}120- \\
194 d\end{array}$ & $400-1750$ & 0.7 & - \\
\hline Cowpea & $15 ; 35 ; 25-35$ & $\begin{array}{c}60- \\
340 d\end{array}$ & $500-1500$ & $0.2-7$ & $12-50$ \\
\hline Fenugreek & $-4 ;-; 18-27$ & $\begin{array}{c}90- \\
100 d\end{array}$ & $300-400$ & - & - \\
\hline Grass pea & $20 ;-; 10-25$ & $\begin{array}{c}90- \\
180 d\end{array}$ & $400-650$ & $\begin{array}{l}0.3- \\
10.5\end{array}$ & $25-50$ \\
\hline Horse gram & $-; 40 ; 20-32$ & $\begin{array}{l}120- \\
150 d\end{array}$ & $380-900$ & 0.5 & - \\
\hline Itching bean & $-;-; 19-27$ & - & $400-3000$ & $0.2-2$ & - \\
\hline Kidney bean & $-1 ; 30 ; 15-20$ & $\begin{array}{c}65- \\
105 d\end{array}$ & $300-600$ & 2.2 & $20-44$ \\
\hline Lablab & - ; - ; 18-30 & $\begin{array}{c}54- \\
220 d\end{array}$ & $650-3000$ & $1.4-4.5$ & $20-140$ \\
\hline Lima bean & $>0 ;>37 ; 16-27$ & $\begin{array}{l}115- \\
180 d\end{array}$ & $900-1500$ & $0.4-5$ & $40-60$ \\
\hline Moth bean & $25 ; 45 ; 24-32$ & $70-90 d$ & $200-750$ & $\begin{array}{c}0.07- \\
2.6\end{array}$ & - \\
\hline Navy bean & $12 ; 35 ; 22-30$ & $\begin{array}{c}53- \\
300 d\end{array}$ & 400 & $0.5-5$ & 125 \\
\hline Pigeon Pea & $0 ; 40 ; 18-29$ & $3-5 y$ & $600-1400$ & $0.6-5$ & 69-134 \\
\hline Pinto bean & $-; 36 ; 21-25$ & $\begin{array}{c}90- \\
100 d\end{array}$ & - & $0.5-3.9$ & - \\
\hline Ricebean & $10 ; 40 ; 25-35$ & $\begin{array}{l}120- \\
150 d\end{array}$ & $700-1700$ & $0.2-2.7$ & - \\
\hline Sword bean & $-;-; 25-30$ & $\begin{array}{l}150- \\
300 d\end{array}$ & $900-1500$ & $1.5-5.4$ & $75-230$ \\
\hline Tarwi & $<0$; - ; - & $\begin{array}{l}150- \\
330 d\end{array}$ & - & $0.6-4.8$ & 100 \\
\hline Tepary bean & $8 ;>32 ; 17-25$ & $\begin{array}{c}60- \\
120 d\end{array}$ & $400-1700$ & $0.4-1.7$ & - \\
\hline Urad & $-;-; 25-35$ no frost & $\begin{array}{c}60- \\
140 d\end{array}$ & $600-1000$ & $0.3-2.5$ & 18 \\
\hline Velvet bean & $5 ;-; 19-27$ & - & $1200-1500$ & $0.5-3.4$ & $60-330$ \\
\hline Winged bean & $-;-; 20-30$ & $\begin{array}{l}120- \\
180 d\end{array}$ & 1000 & $0.7-1.9$ & - \\
\hline Broad bean & $-12 ; 30 ; 18-27$ & $\begin{array}{c}90- \\
220 d\end{array}$ & $700-1200$ & $1.1-2.2$ & $33-550$ \\
\hline Chickpea & $-11 ;>32 ; 10-29$ & $\begin{array}{c}90- \\
180 d\end{array}$ & $500-1800$ & $1-5.5$ & $35-140$ \\
\hline Common bean & $-9 ; 38 ;-$ & $\begin{array}{r}70- \\
110 d\end{array}$ & $274-550$ & $0.9-2.6$ & 465 \\
\hline Field pea & $<0 ;-; 7-30$ & $\begin{array}{c}90- \\
180 d\end{array}$ & $400-1000$ & $1-4$ & $30-96$ \\
\hline Lentil & $2 ; 35 ; 6-27$ & $\begin{array}{c}80- \\
130 d\end{array}$ & $300-2400$ & $0.8-7$ & 50 \\
\hline Lupin & $<0 ;-; 18-24$ & $\begin{array}{l}115- \\
330 d\end{array}$ & $400-1000$ & $0.5-5$ & $90-400$ \\
\hline
\end{tabular}

In temperate climates pulses are mainly cultivated as main crops or in association with cereals [64], whereas in tropical countries, we can find associations with corn [65], 
coffee [66], cassava [67] and other diverse crops [68,69]. In the latter crop, little or no fertilization or pest management is required. Two pulses are cultivated not for theirs grains but for their tuber production, making the grains a co-product (yam bean and African yam bean $[70,71])$. Among the studied species, minimal temperature has been retrieved in 25 species over 57 . Among them few minor pulses resist cold temperatures (Tarwi bean, pigeon pea, kidney bean and fenugreek). Among the major pulses five over six tolerate negative temperatures. The other pulses require positive temperatures during their entire life cycle, and in most cases, above $10^{\circ} \mathrm{C}$. The optimal growing temperature is characterized in the literature only in 33 out of 47 species, but the temperature intervals are often wide. The maximal temperature is retrieved in 23 species over 47 but it will not be a constraint in temperate climates of Western Europe.

Legume plants can fix atmospheric nitrogen (up to $550 \mathrm{kgN} / \mathrm{ha}$ in exceptional examples [60]. Table 3 and Appendix A describe crops requirements and potential yield. Most pulses are grown without adding nitrogen to the crop, even though a small quantity at sowing time can aid in proper development of the plant before the symbiotic relationship with nitrogen-fixing bacteria becomes efficient. It is also recommended that poor soil be fertilized with phosphorus and potassium.

Table 3: Pulses agronomic requirements and potential yields, extracted from Appendix A. - indicates that no data was retrieved from the literature, $\mathrm{d}$ means days (annual crops) and y years (pluriannual crops), ${ }^{\circ} \mathrm{C}$ degrees Celsius.

\begin{tabular}{cccccc}
\hline $\begin{array}{c}\text { Pulses - Common } \\
\text { name }\end{array}$ & $\begin{array}{c}\text { Temperature }\left({ }^{\circ} \mathrm{C}\right) \\
\text { Min; Max; Optimal }\end{array}$ & $\begin{array}{c}\text { Crop } \\
\text { length }\end{array}$ & $\begin{array}{c}\text { Water requirements } \\
(\mathbf{m m})\end{array}$ & $\begin{array}{c}\text { Yield } \\
\text { (t/Ha) }\end{array}$ & $\begin{array}{c}\text { Kg N fixed } \\
\text { (kg/ha) }\end{array}$ \\
\hline Adzuki bean & $5-10 ; 34 ; 15-30$ & $\begin{array}{c}60- \\
190 \mathrm{~d}\end{array}$ & $500-1700$ & $0.5-3.5$ & 100 \\
\hline Butterfly pea & $5 ; 35 ; 20-28$ & $\begin{array}{c}120- \\
194 \mathrm{~d}\end{array}$ & $400-1750$ & 0.7 & - \\
\hline Cowpea & $15 ; 35 ; 25-35$ & $\begin{array}{c}60- \\
340 \mathrm{~d}\end{array}$ & $500-1500$ & $0.2-7$ & $12-50$ \\
\hline Fenugreek & $-4 ;-; 18-27$ & $\begin{array}{c}90- \\
100 \mathrm{~d}\end{array}$ & $300-400$ & - & - \\
\hline Grass pea & $20 ;-; 10-25$ & $\begin{array}{c}90- \\
180 \mathrm{~d}\end{array}$ & $400-650$ & $0.3-$ & $25-50$ \\
\hline Horse gram & $-; 40 ; 20-32$ & $\begin{array}{c}120- \\
150 \mathrm{~d}\end{array}$ & $380-900$ & 0.5 & - \\
\hline Itching bean & $-;-; 19-27$ & - & $400-3000$ & $0.2-2$ & - \\
\hline Kidney bean & $-1 ; 30 ; 15-20$ & $\begin{array}{c}65- \\
105 \mathrm{~d}\end{array}$ & $300-600$ & 2.2 & $20-44$ \\
\hline Lablab & $-;-; 18-30$ & $\begin{array}{c}54- \\
220 \mathrm{~d}\end{array}$ & $650-3000$ & $1.4-4.5$ & $20-140$ \\
\hline Lima bean & $>0 ;>37 ; 16-27$ & $\begin{array}{c}115- \\
180 \mathrm{~d}\end{array}$ & $900-1500$ & $0.4-5$ & $40-60$ \\
\hline Moth bean & $25 ; 45 ; 24-32$ & $70-90 \mathrm{~d}$ & $200-750$ & $0.07-$ & - \\
\hline Navy bean & $12 ; 35 ; 22-30$ & $\begin{array}{c}53- \\
300 \mathrm{~d}\end{array}$ & 400 & $0.5-5$ & 125 \\
\hline Pigeon Pea & $0 ; 40 ; 18-29$ & $3-5 \mathrm{y}$ & $600-1400$ & $0.6-5$ & $69-134$ \\
\hline Pinto bean & $-; 36 ; 21-25$ & $\begin{array}{c}90- \\
100 \mathrm{~d}\end{array}$ & - & $0.5-3.9$ & - \\
\hline Ricebean & $10 ; 40 ; 25-35$ & $\begin{array}{c}120- \\
150 \mathrm{~d}\end{array}$ & $700-1700$ & $0.2-2.7$ & - \\
\hline $\begin{array}{c}150- \\
300 \mathrm{~d}\end{array}$ & $900-1500$ & $1.5-5.4$ & $75-230$ \\
\hline & $-; 25-30$ & & & \\
\hline
\end{tabular}




\begin{tabular}{cccccc}
\hline Tarwi & $<0 ;-;-$ & $\begin{array}{c}150- \\
330 \mathrm{~d}\end{array}$ & - & $0.6-4.8$ & 100 \\
\hline Tepary bean & $8 ;>32 ; 17-25$ & $\begin{array}{c}60- \\
120 \mathrm{~d}\end{array}$ & $400-1700$ & $0.4-1.7$ & 18 \\
\hline Urad & $-;-; 25-35$ no frost & $\begin{array}{c}60- \\
140 \mathrm{~d}\end{array}$ & $600-1000$ & $0.3-2.5$ & $60-330$ \\
\hline Velvet bean & $5 ;-; 19-27$ & - & $1200-1500$ & $0.5-3.4$ & - \\
\hline Winged bean & $-;-; 20-30$ & $\begin{array}{c}120- \\
180 \mathrm{~d}\end{array}$ & 1000 & $0.7-1.9$ & $33-550$ \\
\hline Broad bean & $-12 ; 30 ; 18-27$ & $\begin{array}{c}90- \\
220 \mathrm{~d}\end{array}$ & $700-1200$ & $1.1-2.2$ & $35-140$ \\
\hline Chickpea & $-11 ;>32 ; 10-29$ & $\begin{array}{c}90- \\
180 \mathrm{~d}\end{array}$ & $500-1800$ & $1-5.5$ & 465 \\
\hline Common bean & $-9 ; 38 ;-$ & $\begin{array}{c}70- \\
110 \mathrm{~d}\end{array}$ & $274-550$ & $0.9-2.6$ & $30-96$ \\
\hline Field pea & $<0 ;-; 7-30$ & $\begin{array}{c}90- \\
180 \mathrm{~d}\end{array}$ & $400-1000$ & $1-4$ & $50-400$ \\
\hline Lentil & $2 ; 35 ; 6-27$ & $\begin{array}{c}80- \\
130 \mathrm{~d}\end{array}$ & $300-2400$ & $0.8-7$ & $50-5-5$ \\
\hline
\end{tabular}

The requirements of common pulses are equivalent to those of minor pulses, the main difference is their adaptation to a temperate climate, as they are adapted to low temperatures during a part of their growth cycle. The water needs and fertilization requirements of both are similar. The data collected on the fixed nitrogen cannot be used to make a comparison between species because they were obtained in most of the cases in one single pedo-climatic condition or the methodology to assess it was not identical which may lead to big differences not related to the real capacity of a species to catch up nitrogen $[72,73]$.

\subsection{Nutritional characteristics}

Pulses have an interesting nutritional profile (Table 4, Appendix B), because they have a high protein content with a mean value in our sample of $23 \%$ (rice bean has the lowest content with $19.7 \%$ [74] and tarwi [75] has the highest content, $51 \%$ ), a low fat content with a mean value of $3.8 \%$, and a small percentage of saturated fatty acids. Pulses also provide fibre, vitamins and minerals which are important for human health. Table and Appendix B show the nutritional characteristics of pulses, not taking into account genetic or pedoclimatic variability between species. Vitamins and minerals, when present they were included in Appendix B. It is interesting to note that the values of protein content in minor pulses were comparable to or higher than those of the common pulses already cultivated in North-West Europe.

Table 4 : Nutritional profile of pulses, extracted from Appendix B

\begin{tabular}{cccccc}
\hline $\begin{array}{c}\text { Pulses - Common } \\
\text { name }\end{array}$ & $\begin{array}{c}\text { Energy } \\
\mathbf{( k c a l / 1 0 0 g )}\end{array}$ & $\begin{array}{c}\text { Protein } \\
\mathbf{( \% )}\end{array}$ & $\begin{array}{c}\text { Oil (saturated } \\
\text { FA) } \mathbf{( \% )}\end{array}$ & $\begin{array}{c}\text { Carbohy- } \\
\text { drate (\%) }\end{array}$ & Fibre (\%) \\
\hline Adzuki bean $^{\mathrm{b}}$ & 329 & 19.9 & $0.5(0.2)$ & 62.9 & 12.7 \\
\hline Butterfly pea & - & 25.2 & 3.7 & 19.9 & 9.2 \\
\hline Cowpea & 343 & 23.9 & $2.1(0.5)$ & 59.6 & 10.7 \\
\hline Fenugreek & 323 & 23.0 & 6.4 & 58.0 & 25.0 \\
\hline Grass pea & - & 24.4 & $2.8(0.8)$ & 55.94 & 11.4 \\
\hline Horse gram & 280 & 22 & 0.6 & 37.5 & 5.7 \\
\hline
\end{tabular}




\begin{tabular}{cccccc}
\hline Itching bean & 382 & $27-37$ & $6.6-8.8$ & $46-53$ & $6-10$ \\
\hline Kidney bean & 333 & 23.6 & $0.8(0.1)$ & 30.0 & 24.0 \\
\hline Lablab & 344 & $21-29$ & $1.7(0.3)$ & 60.74 & 25.6 \\
\hline Lima bean & 338 & 21.5 & $0.7(0.2)$ & 63.4 & 19.0 \\
\hline Moth bean & 343 & $23-26$ & $1.6(0.4)$ & 61.5 & 5 \\
\hline Navy bean & 337 & 22.3 & $1.5(0.2)$ & 60.8 & 15.3 \\
\hline Pigeon pea & 343 & $13-26$ & $1.5(0.3)$ & 62.8 & 15 \\
\hline Pinto bean & 347 & 21.4 & $1.2(0.2)$ & 62.6 & 15.5 \\
\hline Rice bean & 338 & $18-19$ & $0.5(0.3)$ & 59.1 & 7.1 \\
\hline Sword bean & 361 & $24-30$ & $2.6-9.8(-)$ & $41-59$ & $7-13$ \\
\hline Tarwi & 440 & $41-51$ & $14-24(19)$ & 28.2 & 7.1 \\
\hline Tepary bean & 353 & $19-24$ & $1.2(-)$ & 67.8 & 4.8 \\
\hline Urad & 341 & 25.2 & $1.6(0.1)$ & 59.0 & 18.3 \\
\hline Velvet bean & 373 & $20-29$ & $6-7$ & $50-61$ & $9-11$ \\
\hline Winged bean & 428 & $30-35$ & $16.3(2.3)$ & 41.7 & $11-26$ \\
\hline Broad bean & 341 & 26.1 & $1.53(0.3)$ & 58.3 & 25 \\
\hline Chickpea & 378 & $11-31$ & $6.0(0.6)$ & 63.0 & 12.2 \\
\hline Common bean & & $20-24$ & $0.8(0.6)$ & 75.5 & - \\
\hline Field pea & 352 & 23.8 & $1.2(0.2)$ & 63.7 & 25 \\
\hline Lentil & 352 & 24.6 & $1.1(0.2)$ & 63.4 & 10.7 \\
\hline Lupin & 371 & 36.2 & $9.7(1.2)$ & 40.37 & 18.9 \\
\hline
\end{tabular}

Other current and largely cultivated crops are also rich in proteins (Appendix C) but often they also have a high fat content making them less nutritionally valuable. Appendix $\mathrm{C}$ describes in the same way as Appendix B the nutritional characteristics of other protein rich crops cultivated or not in temperate regions. For cotton and rapeseed there are nearly no data concerning their nutritional composition as they are mainly used to obtain fibre and oil or oil and proteins respectively, with no direct use as food or feed. A common protein supplement, spirulina (Arthrospira maxima) was also included because of its interesting nutritional profile, highest content of proteins and third lowest level of oil content by comparison.

\subsection{Antinutritional characteristics}

All pulses contain one or more antinutritional compounds (

Appendix ) and although the concentration is under the lethal dose a regular or almost exclusive consumption may induce certain medical problems, such as the lathyrism caused by grass pea in European populations after the wars [76] that led to a law forbidding the consumption of grass pea grain or its derivatives in Spain [77]. Efforts have been made to breed new varieties with a reduced content of the neurotoxin [78].

Appendix reports data from research articles, that analysed one or several compounds. The other columns indicate the presence of other toxic molecules that are only present in some crops, even in a single crop, such as $\beta$-ODAP (beta-oxalyl-diamino-propionic acid) in grass pea or gossypol in cotton. Itching and velvet bean present the highest content of phytic acid with some varieties reaching between 53 and $57 \mathrm{mg} / \mathrm{g}$ [29] whereas the other pulses varied from 0.5 to $41 \mathrm{mg} / \mathrm{g}$. In the case of tannins some varieties of African yam bean contained up to $18.1 \mathrm{mg} / \mathrm{g}$ [79], while other pulses contained from 0.01 [80] to 96 [81] mg/g. Saponins reached the highest values in some varieties of navy bean, but have lower values than some varieties of lentils or chickpea [82]. Trypsin inhibitors were found in high quantities in sesban seeds reaching $140 \mathrm{mg} / 100 \mathrm{~g}$ [83]. Finally, lectins were less abundant in a few species of pulses, mung bean seeds contained the highest quantity with $15,8 \mathrm{mg}$ per $100 \mathrm{~g}$ [84]. 
No pulse exceeded the lethal dose estimated at $50-60 \mathrm{mg} / \mathrm{kg}$ for phytates, $30 \mathrm{mg} / \mathrm{kg}$ for tannins, $2.5 \mathrm{~g} / \mathrm{kg}$ for trypsin inhibitors, $50 \mathrm{mg} / \mathrm{kg}$ for lectins, $50-60 \mathrm{~g} / \mathrm{kg}$ for hydrogen cyanide or $20 \mathrm{mg} / 100 \mathrm{~g}$ and $2-5 \mathrm{~g} / \mathrm{kg}$ for oxalates [85]. Nevertheless, the presence of these antinutritional compounds may cause some troubles. Phytic acid chelates with several minerals limiting their bioavailability for the organism. Tannins reduce the absorption of nutriments and vitamin B12, reducing the efficiency of energy conversion [86]. Cooking or transforming these pulses inactivates the negative effects of these antinutritional factors on health or wellbeing [87].

\subsection{Potential for minor pulse cultivation in European temperate regions}

Analyses of the meteorological data showed that in the considered European temperate regions between 1998 and 2018, the total number of observed situations was 7456 . The minimal duration of good cropping conditions was 121 days, and the average maximum was 140 days. The most frequent duration was 120-125 days (18.5\%) followed by $125-130(15.3 \%)$ and $130-135$ days (10.5\%). The daily temperature varied from 14.9 to 20.0 ${ }^{\circ} \mathrm{C}$, with a mean of $17.1^{\circ} \mathrm{C}$. Sowing was possible in $12.6 \%$ of the situations in March, 54.1 $\%$ in April, $34.0 \%$ in May and only $1.8 \%$ in June, whereas the possible harvest day was concentrated between September (64.7\%) and October (33.6\%). The GDD in base $6{ }^{\circ} \mathrm{C}$ varied from 1102 to $2430{ }^{\circ} \mathrm{C}$ day, the most frequent being 1500 to $1600{ }^{\circ} \mathrm{Cday}(19 \%), 1600$ $1700{ }^{\circ} \mathrm{C}$ day $(18.3 \%), 1400-1500(16.2 \%)$ and $1700-1800(13.2 \%)$. The GDD in base $10^{\circ} \mathrm{C}$ varied from 615 to $1654^{\circ} \mathrm{C}$ day with a mean of $994^{\circ} \mathrm{C}$ day being the most frequent $1000-1100$ (25.5\%), followed by $1100-1200(20.6 \%)$ and $900-1000$ (20.2\%) (Figure 4).

Base $10\left({ }^{\circ} \mathrm{C}\right) \square$ Base $6\left({ }^{\circ} \mathrm{C}\right)$

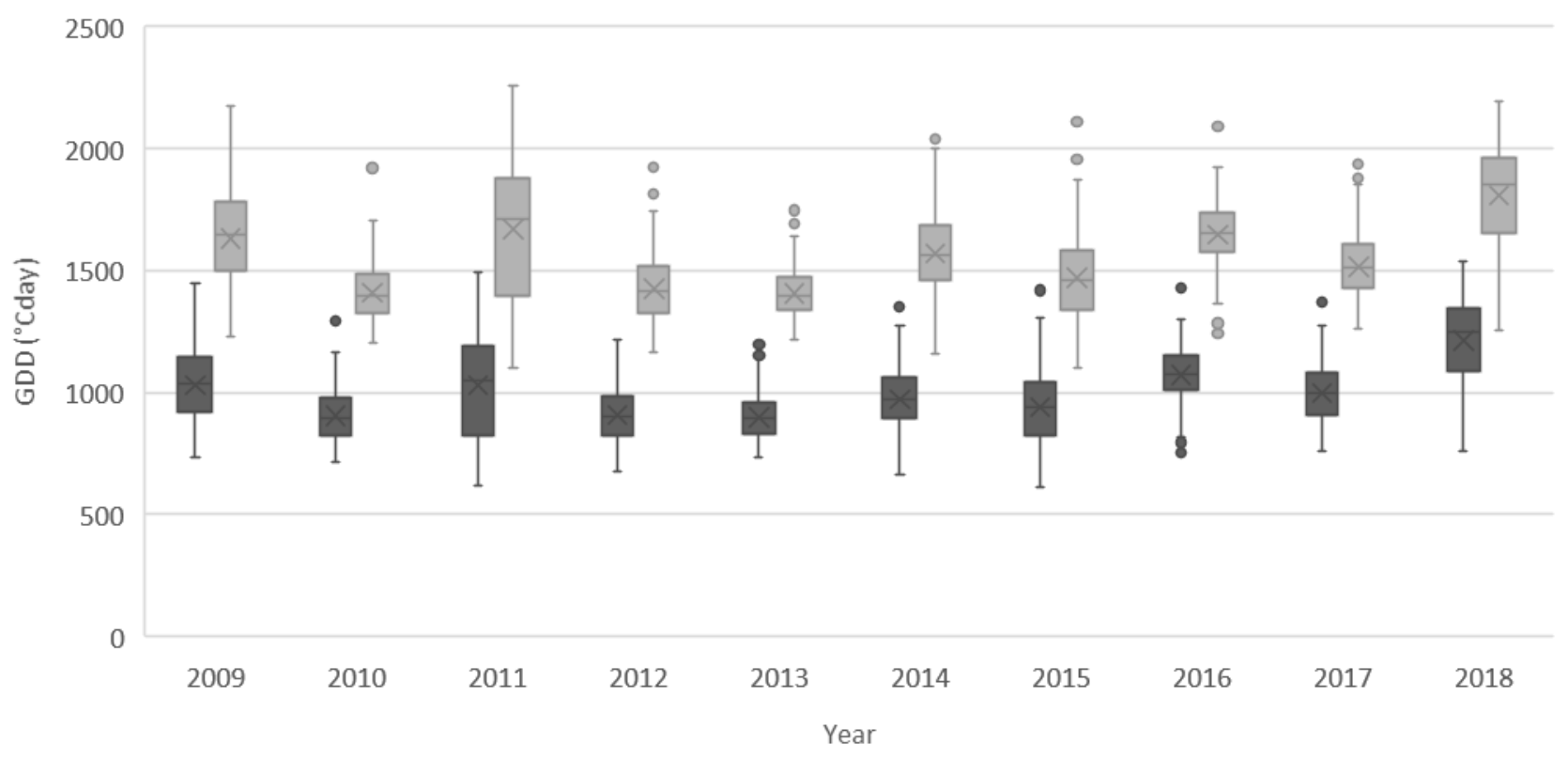

Figure 4: Bow whispers of the Growing Degrees Days (GDD, ${ }^{\circ} \mathrm{C}$ day) cumulative distributions in several locations in European temperate regions (see paragraph 2.3) within the last 10 studied years for a base temperature of 6 and $10^{\circ} \mathrm{C}$ (Source: own calculation from the Agri4cast database).

By applying the criteria of crop needs and the possibility of reaching the GDD necessary to attain crop maturity, compared to other spring crops already cultivated in those regions, almost half the selected grain legume crops (21) appeared to be of interest for temperate cropping systems. Those species are the one listed in tables 2 and 3. 


\section{Conclusions}

The present systematic review has shown the agronomic and nutritional interests of almost 20 pulses beyond the major ones which could be cultivated in Western European temperate regions. At this stage this possibility is theorical as there are several gaps in the literature. Firstly, there is a lack of physiological data, especially for minor pulses whereas for major pulses information could be retrieved but only for the current cultivation area. Particularly, data concerning the optimal and minimal growing temperatures, the GDD requirements to reach physiological maturity as well as the minimal water requirements are missing. Secondly, there is little information about soil constraints such as the soil structure, soil depth, $\mathrm{pH}$ or soil water availability. Pests and diseases are described for most pulses, even for those species with few references. Thirdly, beyond the species level, there is a lack of knowledge about the genetic diversity that could be useful to extend the cultivation area, as the characterisation that is retrieved in scientific literature is not sufficient to the best of our knowledge. Probably, in seedbanks, the information available will be more exhaustive for assessing certain traits such as crop length or disease resistance but this information will not be enough to establish the potential crop length in climatic areas other than those where genetic material has been collected. Among the 20 pulses with the highest cultivation potential in temperate areas, we have found that both their nutritional and anti-nutritional characteristics are comparable to those of the major pulses already cropped and consumed in these areas. Technological characteristics, processing potential and consumer preferences were outside of the scope of this review; however, all the retrieved species are already consumed as raw food or food components in different parts of the world. The potential of these species for other uses than as food, i.e. feed (grain or forage) or no food (bio-plastic) were also outside of the scope of this literature review but they can be considered worthy of investigation when contemplating the development of a new supply chain.

From these conclusions, we can highlight three main research perspectives when addressing the introduction of these pulses in Western European temperate areas. These are traditional perspectives when considering the introduction of a new crop to different environments, as occurred for example with quinoa. Firstly, a characterisation of the requirements of the pulses in a controlled environment is necessary to identify their growing needs in order to adapt the crop management to obtain the maximum potential yield. Then, multi-site and pluriannual field trials are required to establish the optimal pedoclimatic conditions and management practices. In parallel, a second perspective concerns the great effort that must be undertaken to study the existing genetic diversity in order to find the varieties that are most adapted to temperate conditions. This effort will require a large collaboration with seedbanks in order to characterise this diversity. Finally, a third perspective will concern a breeding program to improve the existing varieties. These three perspectives are a necessary first step before considering the adoption by local farmers and the introduction to cropping systems in temperate areas.

Author Contributions: Conceptualization, A.A.G. and E.M.; methodology, A.A.G. and E.M.; formal analysis, A.A.G and E.M.; writing - original draft, A.A.G. and E.M.; writing - review and editing, A.A.G. and E.M.; Supervision, A.A.G. and E.M. All authors have read and agreed to the published version of the manuscript.

Funding: Thjs review was partially funded by the SFR Condorcet with the project CALEGE 2021.

Data Availability Statement: The datasets analyzed during the current study are available from the corresponding author on reasonable request.

Acknowledgments: We acknowledge the contribution in a first stage of the literature review of Sophie Bonningues and Gauranvi, interns at UniLaSalle (France). We also acknowledge our colleagues Michel-Pierre Faucon and Pierre Saulet for the useful discussions and the Agri4cast data extraction.

Conflicts of Interest: The authors declare no conflict of interest. 


\begin{tabular}{|c|c|c|c|c|c|c|c|c|c|c|c|}
\hline \multicolumn{12}{|c|}{ Appendix A : Agronomic requirements of minor and major pulses } \\
\hline $\begin{array}{c}\text { Pulses - Common } \\
\text { name }\end{array}$ & $\begin{array}{l}\text { Climate re- } \\
\text { gion }\end{array}$ & $\begin{array}{l}\text { Countries } \\
\text { where culti- } \\
\text { vated }\end{array}$ & $\begin{array}{c}\text { Temperature } \\
\left({ }^{\circ} \mathrm{C}\right) \\
\text { Min; Max; Opti- } \\
\text { mal }\end{array}$ & $\begin{array}{l}\text { Crop } \\
\text { length }^{\mathrm{a}}\end{array}$ & $\begin{array}{l}\text { Water re- } \\
\text { quire- } \\
\text { ments } \\
(\mathrm{mm})\end{array}$ & $\begin{array}{l}\text { Mineral re- } \\
\text { quirements }\end{array}$ & Pest risk ${ }^{b}$ & $\begin{array}{l}\text { Yield } \\
(\mathrm{t} / \mathrm{Ha})\end{array}$ & $\begin{array}{c}\mathrm{Kg} \mathrm{N} \text { fixed } \\
\text { (kg/ha) }\end{array}$ & $\begin{array}{c}\text { Bacteria associ- } \\
\text { ated }\end{array}$ & References \\
\hline Acacia leucophloea & Tropic & $\begin{array}{l}\text { Bangladesh, } \\
\text { India, Indone- } \\
\text { sie, Pakistan }\end{array}$ & $6 ; 49 ;-$ & $\mathrm{Y}($ tree $)$ & $400-1500$ & & $F ; I$ & & & & [88] \\
\hline Adzuki bean & Tropic & $\begin{array}{l}\text { China, Japan, } \\
\text { Korea, Nepal }\end{array}$ & $5-10 ; 34 ; 15-30$ & $60-190 d$ & $500-1700$ & $\mathrm{~N}, \mathrm{P}, \mathrm{K}$ & $\mathrm{B} ; \mathrm{F} ; \mathrm{I}$ & $0.5-3.5$ & 100 & $\begin{array}{l}\text { Bradyrhizobium } \\
\text { spp.; Sinorhizo- } \\
\text { bium fredii }\end{array}$ & [89-97] \\
\hline African locust bean & Tropic & $\begin{array}{l}\text { Sudan, } \\
\text { Uganda }\end{array}$ & $0 ; 45 ; 21-36$ & $\mathrm{Y}($ tree $)$ & $500-1500$ & & $B ; F ; I$ & & & & {$[98,99]$} \\
\hline African nut tree & Tropic & $\begin{array}{c}\text { West and } \\
\text { Central Africa, } \\
\text { Madagascar }\end{array}$ & -; -; 18-32 & $\mathrm{Y}($ tree $)$ & 1000 & & & & & & {$[60,99]$} \\
\hline African oil bean & Tropic & $\begin{array}{l}\text { Sub-Sahara } \\
\text { Africa }\end{array}$ & $18 ;-; 25$ & $\mathrm{Y}($ tree $)$ & $1000-2000$ & & I & & & & {$[60,99]$} \\
\hline African yam bean & Tropic & $\begin{array}{l}\text { Ghana, Nige- } \\
\text { ria, Togo }\end{array}$ & $0 ;-; 19-27$ & $150-240 d$ & $900-2000$ & & $F ; I$ & $3 A^{*}$ & & & {$[90,98,100]$} \\
\hline Bambara groundnut & Tropic & $\begin{array}{c}\text { Australia, } \\
\text { Cameroun, Ni- } \\
\text { geria, Sudan }\end{array}$ & $\begin{array}{c}15 ; 40 ; 20-28: \\
\text { no frost }\end{array}$ & $90-180 d$ & $600-1200$ & $\mathrm{~N}, \mathrm{P}, \mathrm{K}$ & $\mathrm{F} ; \mathrm{I} ; \mathrm{N} ; \mathrm{V}$ & $0.1-6$ & 100 & $\begin{array}{l}\text { Bradyrhizobium } \\
\text { spp }\end{array}$ & {$[90,100-109]$} \\
\hline Butterfly pea & Tropic & $\begin{array}{l}\text { Brazil, Colom- } \\
\text { bia, India, Me- } \\
\text { xico, Philippi- } \\
\text { nes, Vene- } \\
\text { zuela }\end{array}$ & $5 ; 35 ; 20-28$ & $120-194 d$ & $400-1750$ & & $\mathrm{~F} ; \mathrm{I} ; \mathrm{B}$ & 0.7 & & Rhizobium & [110-114] \\
\hline Cowpea & Tropic & $\begin{array}{c}\text { Burkina Faso, } \\
\text { Ghana, Mali, } \\
\text { Senegal }\end{array}$ & $\begin{array}{c}15 ; 35 ; 25-35 \\
\text { no frost }\end{array}$ & $60-340 d$ & $500-1500$ & $\mathrm{~N}, \mathrm{P}, \mathrm{K}$ & $\begin{array}{c}F ; I ; P ; W ; \\
V\end{array}$ & $0.2-7$ & $12-50$ & $\begin{array}{c}\text { Rhizobium spp. } \\
\text { NGR234; Bradyr- } \\
\text { hizobium spp.; } \\
\text { Sinorhizobium } \\
\text { fredii } \\
\end{array}$ & $\begin{array}{c}{[60,61,100,115-} \\
124]\end{array}$ \\
\hline Ervil & Temperate & $\begin{array}{c}\text { Australia, Iran, } \\
\text { Morocco, Tur- } \\
\text { key }\end{array}$ & & $134-154 d$ & $200-500$ & & & $0.6-4$ & & & [125-129] \\
\hline
\end{tabular}




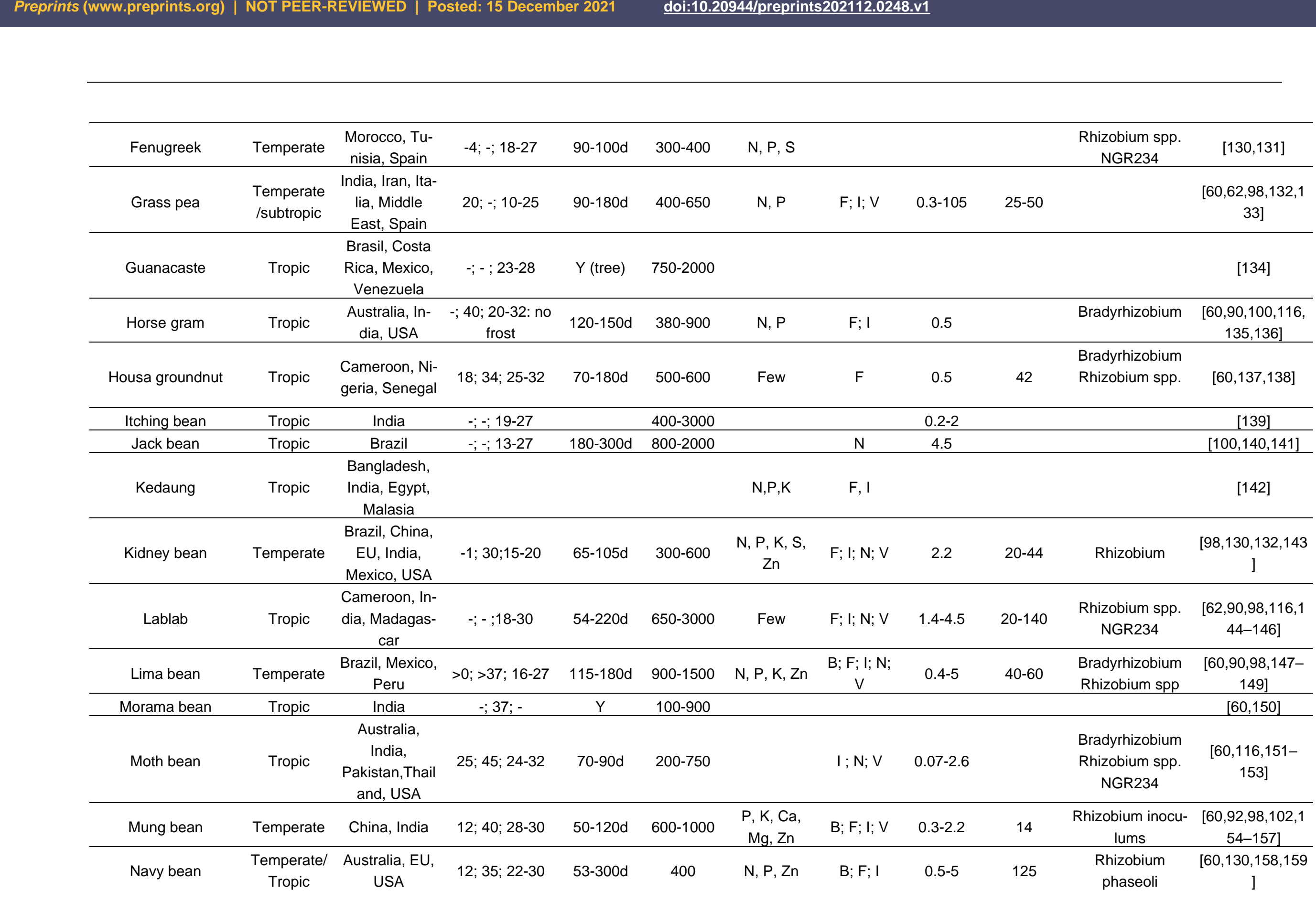




\begin{tabular}{|c|c|c|c|c|c|c|c|c|c|c|c|}
\hline Narbon bean & Temperature & $\begin{array}{l}\text { Australia, Irak } \\
\text { Italy, Jordan, } \\
\text { Portugal, } \\
\text { Spain, Turkey }\end{array}$ & $30 ;-;-$ & $170 d$ & $200-500$ & & $\begin{array}{c}\mathrm{W} ; \mathrm{F} ; \mathrm{I} ; \mathrm{N} ; \\
\mathrm{V}\end{array}$ & $0.5-2$ & & & $\begin{array}{c}{[126,127,160-} \\
163]\end{array}$ \\
\hline Pigeon Pea & Tropic & $\begin{array}{l}\text { India, Kenia, } \\
\text { Malawi, Myan- } \\
\text { mar, Nepal, } \\
\text { Tanzania, } \\
\text { Uganda }\end{array}$ & $\begin{array}{c}0 ; 40 ; 18-29: \text { no } \\
\text { frost }\end{array}$ & $3-5 y$ & $600-1400$ & $\mathrm{P}$ & I; N & $0.6-5$ & $69-134$ & $\begin{array}{c}\text { Bradyrhizobium } \\
\text { spp. }\end{array}$ & $\begin{array}{c}{[62,92,98,102,1} \\
41,164-166]\end{array}$ \\
\hline Pinto bean & Temperate & USA & $-; 36 ; 21-25$ & $90-100$ & & & B; V & $0.5-3.9$ & & & {$[167,168]$} \\
\hline Pinto peanut & Tropic & $\begin{array}{c}\text { Argentina, } \\
\text { Brasil, Colom- } \\
\text { bia, USA }\end{array}$ & $-;-;$ 21-30 & & $1100-1500$ & $\mathrm{~K}, \mathrm{Al}, \mathrm{Mn}$ & $\mathrm{F} ; \mathrm{N} ; \mathrm{V}$ & $0.3-3$ & & & {$[62,169-171]$} \\
\hline Purple mucuna & Tropic & India & $-; 19-27 ;-$ & $Y$ & $400-3000$ & & & & & & \\
\hline Red moneywort & $\begin{array}{c}\text { Temperate/ } \\
\text { Tropic }\end{array}$ & $\begin{array}{l}\text { Australia, } \\
\text { Asia, Mada- } \\
\text { gascar }\end{array}$ & & & $600-1500$ & & & 3-7.5 & & Bradyrhizobium & [172] \\
\hline Ricebean & $\begin{array}{l}\text { Temperate- } \\
\text { Tropic (Alt } \\
\approx 2000 \mathrm{~m}) \\
\end{array}$ & $\begin{array}{c}\text { Bangladesh, } \\
\text { China, India, } \\
\text { Nepal }\end{array}$ & $10 ; 40 ; 25-35$ & $120-150 d$ & $700-1700$ & $P$ & $\mathrm{~B} ; \mathrm{F} ; \mathrm{I}$ & $0.2-2.7$ & & $\begin{array}{l}\text { Rhizobium spp. } \\
\text { NGR234 }\end{array}$ & $\begin{array}{c}{[60,90,102,116} \\
173-176]\end{array}$ \\
\hline Scarlet runner bean & $\begin{array}{l}\text { Temperate- } \\
\text { Tropic (Alt } \approx \\
2000 \mathrm{~m})\end{array}$ & $\begin{array}{l}\text { Africa, Central } \\
\text { \& South } \\
\text { America, EU }\end{array}$ & $5 ;>37 ; 25$ & $120-150 d$ & 1500 & $\mathrm{~F}$ & $\mathrm{~F}$ & $0.9-12.5$ & & Rhizobium & {$[60,149,177]$} \\
\hline Sesban & Tropic & $\begin{array}{c}\text { Chad, Egypt, } \\
\text { Kenya, } \\
\text { Uganda }\end{array}$ & $7 ; 45 ; 17-20$ & $\mathrm{Y}($ tree $)$ & $500-2000$ & $\mathrm{P}, \mathrm{K}$ & F; I; N; V & & & $\begin{array}{l}\text { Rhizobium legu- } \\
\text { minosarum, Brad- } \\
\text { yrhizobium }\end{array}$ & $\begin{array}{c}{[98,172,178-} \\
180]\end{array}$ \\
\hline Sword bean & Tropic & India & $-;-; 25-30$ & $150-300 d$ & $900-1500$ & & $\mathrm{~F} ; \mathrm{I} ; \mathrm{N}$ & $1.5-5.4$ & $75-230$ & & {$[60,98]$} \\
\hline Tamarind & Tropic & $\begin{array}{c}\text { Australia, } \\
\text { Cameroon, } \\
\text { China, India, } \\
\text { Mexico, Nige- } \\
\text { ria } \\
\end{array}$ & $4 ; 41 ; 15-28$ & $\mathrm{Y}$ (tree) & $32-3800$ & $P$ & B. F; I; N & & & & [181-185] \\
\hline Tarwi & $\begin{array}{l}\text { Temperate } \\
\quad(\text { Alt } \\
\approx 3000 \mathrm{~m})\end{array}$ & $\begin{array}{l}\text { South Amer- } \\
\text { ica }\end{array}$ & $<0 ;-;-$ & $150-330 d$ & & $\mathrm{~N}, \mathrm{P}$ & $\mathrm{F} ; \mathrm{I} ; \mathrm{V}$ & $0.6-4.8$ & 100 & & {$[90,186]$} \\
\hline
\end{tabular}




\begin{tabular}{|c|c|c|c|c|c|c|c|c|c|c|c|}
\hline Tepary bean & $\begin{array}{l}\text { Temperate/ } \\
\text { Tropic }\end{array}$ & $\begin{array}{l}\text { Guatemala, } \\
\text { Mexico, USA }\end{array}$ & $8 ;>32 ; 17-25$ & $60-120 d$ & $400-1700$ & $P$ & $\begin{array}{c}\mathrm{B} ; \mathrm{F} ; \mathrm{I} ; \mathrm{N} \text {; } \\
\mathrm{V}\end{array}$ & $0.4-1.7$ & & $\begin{array}{c}\text { Bradyrhizobium, } \\
\text { Rhizobium legu- } \\
\text { minosarum bv. } \\
\text { phaseoli }\end{array}$ & $\begin{array}{c}{[60,90,130,149} \\
187]\end{array}$ \\
\hline Urad & Tropic & $\begin{array}{l}\text { India, Paki- } \\
\text { stan }\end{array}$ & $\begin{array}{c}-;-; 25-35 \text { no } \\
\text { frost }\end{array}$ & $60-140 d$ & $600-1000$ & $P, B$ & $F ; I$ & $0.3-2.5$ & 18 & $\begin{array}{l}\text { Bradyrhizobium } \\
\text { yuanmingense }\end{array}$ & $\begin{array}{c}{[61,154,155,188} \\
]\end{array}$ \\
\hline Velvet bean & Tropic & India & $5 ;-; 19-27$ & $D$ or $Y$ & $1200-1500$ & & $\mathrm{I} ; \mathrm{N}$ & $0.5-3.4$ & $60-330$ & $\begin{array}{l}\text { Bradyrhizobium } \\
\text { sp. }\end{array}$ & {$[90,98,189-193]$} \\
\hline Winged bean & Tropic & $\begin{array}{c}\text { India, } \\
\text { Indonesia, } \\
\text { Philipines, Sri } \\
\text { Lanka } \\
\end{array}$ & $-;-; 20-30$ & $120-180 d$ & 1000 & & $F ; I$ & $0.7-1.9$ & & $\begin{array}{c}\text { Rhizobium spp. } \\
\text { NGR234 }\end{array}$ & {$[116,194]$} \\
\hline Yam bean & Tropic & $\begin{array}{c}\text { Costa Rica, } \\
\text { India, Mexico, } \\
\text { Peru }\end{array}$ & -; 35-40; - & $2 Y$ & & $\mathrm{~N}, \mathrm{P}, \mathrm{K}$ & $\mathrm{N} ; \mathrm{I}$ & $A^{*}$ & $165-215$ & $\begin{array}{l}\text { Rhizobium spp. } \\
\text { NGR234 }\end{array}$ & $\begin{array}{c}{[63,116,195,196} \\
]\end{array}$ \\
\hline Broad bean & $\begin{array}{l}\text { Temperate/ } \\
\text { Tropic }\end{array}$ & $\begin{array}{l}\text { Australia, } \\
\text { China, Ethio- } \\
\text { pia, EU, Jor- } \\
\text { dan, USA } \\
\end{array}$ & $-12 ; 30 ; 18-27$ & $90-220 d$ & $700-1200$ & $\mathrm{~N}, \mathrm{P}, \mathrm{K}, \mathrm{Ca}$ & F; I; N; V & $1.1-2.2$ & $33-550$ & $\begin{array}{c}\text { Rhizobium } \\
\text { Leguminosarum }\end{array}$ & $\begin{array}{c}{[60,92,98,130,1} \\
32,197,198]\end{array}$ \\
\hline Chickpea & $\begin{array}{l}\text { Temper- } \\
\text { ate/Tropic }\end{array}$ & $\begin{array}{l}\text { EU, Middle } \\
\text { East, South } \\
\text { Africa }\end{array}$ & $-11 ;>32 ; 10-29$ & $90-180 d$ & $500-1800$ & $P, Z n, S, B$ & F; I; N; V & $1-5.5$ & $35-140$ & Rhizobium cicerii & $\begin{array}{c}{[60,92,98,130,1} \\
54,197,199- \\
203]\end{array}$ \\
\hline Common bean & Temperate & $\begin{array}{c}\text { Australia, Af- } \\
\text { rica, Canada, } \\
\text { EU, Middle } \\
\text { East, USA } \\
\end{array}$ & $-9 ; 38 ;-$ & $70-110 d$ & $274-550$ & $\mathrm{~N}, \mathrm{P}, \mathrm{S}, \mathrm{Mo}$ & $\mathrm{F} ; \mathrm{I} ; \mathrm{V}$ & $0.9-2.6$ & 465 & $\begin{array}{l}\text { Rhizobium legu- } \\
\text { minosarum; Rhi- } \\
\text { zobium tropici }\end{array}$ & [204-215] \\
\hline Field pea & $\begin{array}{l}\text { Temperate/ } \\
\text { Tropic }\end{array}$ & $\begin{array}{l}\text { Canada, } \\
\text { China, EU, In- } \\
\text { dia,Russia }\end{array}$ & $<0 ;-; 7-30$ & $90-180 d$ & $400-1000$ & $\mathrm{~N}, \mathrm{P}, \mathrm{K}, \mathrm{Mg}$ & F; I; N; V & $1-4$ & $30-96$ & $\begin{array}{l}\text { Rhizobium legu- } \\
\text { minosarum }\end{array}$ & $\begin{array}{l}{[60,92,98,130,1} \\
32,157,197,216]\end{array}$ \\
\hline Lentil & Temperate & $\begin{array}{l}\text { Australia, } \\
\text { Canada, EU, } \\
\text { Middle East }\end{array}$ & $2 ; 35 ; 6-27$ & $80-130 d$ & $300-2400$ & $\mathrm{~N}, \mathrm{P}, \mathrm{K}$ & F; I; N; V & $0.8-7$ & 50 & Rhizobium & $\begin{array}{c}{[60,92,98,102,1} \\
30,154,197,217, \\
218]\end{array}$ \\
\hline Lupin & Temperate & $\begin{array}{c}\text { Australia, EU, } \\
\text { Middle East, } \\
\text { Ukraine }\end{array}$ & $<0 ;-; 18-24$ & $115-330 d$ & $400-1000$ & $\mathrm{P}, \mathrm{Fe}$ & $F ; I ; V$ & $0.5-5$ & $90-400$ & Rhizobium lupini & $\begin{array}{c}{[60,92,98,132,1} \\
97,219-222]\end{array}$ \\
\hline
\end{tabular}


${ }^{\mathrm{a} D}$ : days; $\mathrm{y}$ : years;

${ }^{*} \mathrm{~A}$ : The tuber of the plant is the main crop use

${ }^{b}$ Pests: Fungi (F); Insects (I); Bacteria (B); Nematodes (N); Virus (V); Parasite weeds (PW)

Appendix B: Nutritional composition of minor pulses

\begin{tabular}{|c|c|c|c|c|c|c|c|c|}
\hline $\begin{array}{c}\text { Pulses - Common } \\
\text { name }\end{array}$ & $\begin{array}{c}\text { Energy } \\
(\mathrm{kcal} / 100 \\
\mathrm{g})\end{array}$ & $\begin{array}{l}\text { Protein } \\
(\%)\end{array}$ & $\begin{array}{c}\text { Oil (satu- } \\
\text { rated FA) } \\
(\%)\end{array}$ & $\begin{array}{l}\text { Carbohy- } \\
\text { drate (\%) }\end{array}$ & $\begin{array}{c}\text { Fibre } \\
(\%)\end{array}$ & Vitamins & Minerals & Reference \\
\hline Acacia leucophloea & 382 & 27 & 5 & 58 & 7 & & $\mathrm{Ca}, \mathrm{Fe}, \mathrm{Mg}, \mathrm{P}, \mathrm{K}, \mathrm{Na}, \mathrm{Zn}, \mathrm{Cu}, \mathrm{Mn}$ & {$[88,223]$} \\
\hline Adzuki bean ${ }^{b}$ & 329 & 19.9 & $0.5(0.2)$ & 62.9 & 12.7 & $\mathrm{~B}_{1}, \mathrm{~B}_{2}, \mathrm{~B}_{3}, \mathrm{~B}_{6}, \mathrm{~B}_{9}, \mathrm{~A}$ & $\mathrm{Ca}, \mathrm{Fe}, \mathrm{Mg}, \mathrm{P}, \mathrm{K}, \mathrm{Na}, \mathrm{Zn}$ & {$[224,225]$} \\
\hline African locust bean & 414 & $24-34$ & $19-23$ & 67 & 11.7 & C & $\mathrm{Ca}, \mathrm{Fe}, \mathrm{Mg}, \mathrm{K}, \mathrm{Na}, \mathrm{Zn}, \mathrm{Cu}, \mathrm{Mn}$ & {$[99,226-230]$} \\
\hline African nut bean & 649 & 26.3 & 58.1 & 4.6 & 2.7 & & $\mathrm{Ca}, \mathrm{Fe}, \mathrm{Mg}, \mathrm{P}, \mathrm{Zn}, \mathrm{Cu}$ & [99] \\
\hline African oil bean & 206 & 48.5 & 33.4 & 8.9 & 6.3 & $\mathrm{C}, \mathrm{B}_{1}, \mathrm{~B}_{2}, \mathrm{~B}_{3}$ & $\mathrm{Ca}, \mathrm{Fe}, \mathrm{Mg}, \mathrm{P}, \mathrm{K}, \mathrm{Na}, \mathrm{Cu}, \mathrm{Mn}, \mathrm{Pb}$ & {$[70,99,229,231]$} \\
\hline African yam bean & 365 & 20.5 & $1-12.2$ & $65-78$ & $7-12$ & & $\mathrm{Ca}, \mathrm{Fe}, \mathrm{Mg}, \mathrm{P}, \mathrm{K}, \mathrm{Na}, \mathrm{Zn}, \mathrm{Cu}, \mathrm{Mn}$ & {$[70,79,232,233]$} \\
\hline Bambara groundnut & 408 & $18-30$ & $6.2(2.0)$ & $\begin{array}{r}33.4- \\
68.5\end{array}$ & 1.9 & $\mathrm{C}, \mathrm{B}_{1}, \mathrm{~B}_{2}, \mathrm{~B}_{3}$ & $\mathrm{Ca}, \mathrm{Fe}, \mathrm{Mg}, \mathrm{P}, \mathrm{K}, \mathrm{Na}, \mathrm{Se}$ & {$[75,104,234-238,238]$} \\
\hline Butterfly pea & - & 25.2 & 3.7 & 19.9 & 9.2 & & $\mathrm{Ca}, \mathrm{P}$ & [239] \\
\hline Cowpea & 343 & 23.9 & $2.1(0.5)$ & 59.6 & 10.7 & $\mathrm{C}, \mathrm{B}_{1}, \mathrm{~B}_{2}, \mathrm{~B}_{3}, \mathrm{~B}_{6}, \mathrm{~B}_{9}, \mathrm{~A}$ & $\mathrm{Fe}, \mathrm{Mg}, \mathrm{Zn}, \mathrm{Cu}, \mathrm{Mn}, \mathrm{Cr}, \mathrm{Ni}, \mathrm{Al}, \mathrm{Pb}$ & {$[75,224,240,241]$} \\
\hline Ervil & 324 & $20-28$ & $11-16$ & 61 & & & $\mathrm{Ca}, \mathrm{Fe}, \mathrm{Mg}, \mathrm{P}, \mathrm{K}, \mathrm{Na}, \mathrm{Zn}, \mathrm{Cu}, \mathrm{Mn}$ & [242-246] \\
\hline Fenugreek & 323 & 23.0 & 6.4 & 58.0 & 25.0 & $\mathrm{C}, \mathrm{B}_{1}, \mathrm{~B}_{2}, \mathrm{~B}_{3}, \mathrm{~B}_{6}, \mathrm{~B}_{9}$ & $\mathrm{Ca}, \mathrm{Fe}, \mathrm{Mg}, \mathrm{P}, \mathrm{K}, \mathrm{Na}, \mathrm{Zn}, \mathrm{Mn}$ & {$[224,247,248]$} \\
\hline Grass pea & - & 24.4 & $2.8(0.8)$ & 55.94 & 11.4 & $\mathrm{C}, \mathrm{B}_{1}, \mathrm{~B}_{2}$ & $\mathrm{Ca}, \mathrm{Fe}, \mathrm{Mg}, \mathrm{P}, \mathrm{Zn}$ & {$[156,223,249]$} \\
\hline Guanacaste & - & 33.9 & $2.8(0.1)$ & 56.8 & 1.3 & & $\mathrm{Ca}, \mathrm{Fe}, \mathrm{Mg}, \mathrm{K}, \mathrm{Na}, \mathrm{Zn}, \mathrm{Cu}$ & {$[239,250]$} \\
\hline Horse gram & 280 & 22 & 0.6 & 37.5 & 5.7 & & $\mathrm{Ca}, \mathrm{Fe}, \mathrm{Mg}, \mathrm{P}, \mathrm{Zn}, \mathrm{Mn}, \mathrm{Cu}$ & [251-253] \\
\hline Housa groundnut & 367 & $19-21$ & 1.1 & $67-74$ & 5.5 & $\mathrm{C}, \mathrm{B}_{1}, \mathrm{~B}_{2}, \mathrm{~B}_{3}$ & $\mathrm{Ca}, \mathrm{Fe}, \mathrm{P}, \mathrm{K}$ & {$[75,224]$} \\
\hline Itching bean & 382 & $27-37$ & $6.6-8.8$ & $46-53$ & $6-10$ & $\mathrm{C}, \mathrm{B}_{3}$ & $\mathrm{Ca}, \mathrm{Fe}, \mathrm{Mg}, \mathrm{P}, \mathrm{K}, \mathrm{Na}, \mathrm{Cu}, \mathrm{Mn}$ & {$[29,254,255]$} \\
\hline Jack bean & 389 & $21-27$ & $3.5(0.3)$ & 60.6 & $2-8$ & - & $\mathrm{Ca}, \mathrm{Fe}, \mathrm{Mg}, \mathrm{P}, \mathrm{K}, \mathrm{Na}, \mathrm{Zn}, \mathrm{Cu}, \mathrm{Mn}, \mathrm{Pb}$ & {$[75,256,257]$} \\
\hline Kedaung & & 20.1 & $20(13)$ & & 0.98 & & $\mathrm{Ca}, \mathrm{Fe}, \mathrm{Mg}, \mathrm{P}, \mathrm{K}, \mathrm{Na}, \mathrm{Zn}, \mathrm{Cu}, \mathrm{Mn}$ & {$[258,259]$} \\
\hline Kidney bean & 333 & 23.6 & $0.8(0.1)$ & 30.0 & 24.0 & $\mathrm{C}, \mathrm{B}_{1}, \mathrm{~B}_{2}, \mathrm{~B}_{3}, \mathrm{~B}_{9}, \mathrm{~K}, \mathrm{E}$ & $\mathrm{Ca}, \mathrm{Fe}, \mathrm{Mg}, \mathrm{P}, \mathrm{K}$ & {$[224,240,260]$} \\
\hline Lablab & 344 & $21-29$ & $1.7(0.3)$ & 60.74 & 25.6 & $\mathrm{~B}_{1}, \mathrm{~B}_{2}, \mathrm{~B}_{3}, \mathrm{~B}_{6}, \mathrm{~B}_{9}$ & $\mathrm{Ca}, \mathrm{Fe}, \mathrm{Mg}, \mathrm{P}, \mathrm{K}, \mathrm{Na}, \mathrm{Zn}$ & {$[75,224,261,262]$} \\
\hline Lima bean & 338 & 21.5 & $0.7(0.2)$ & 63.4 & 19.0 & $\mathrm{~B}_{1}, \mathrm{~B}_{2}, \mathrm{~B}_{3}, \mathrm{~B}_{6}, \mathrm{~B}_{9}, \mathrm{~K}, \mathrm{E}$ & $\mathrm{Ca}, \mathrm{Fe}, \mathrm{Mg}, \mathrm{P}, \mathrm{K}, \mathrm{Na}, \mathrm{Zn}$ & {$[224,233]$} \\
\hline Morama bean & 635 & $29-38$ & $32-42(10)$ & 18.9 & $19-27$ & $\mathrm{E}$ & $\mathrm{Ca}, \mathrm{Fe}, \mathrm{Mg}, \mathrm{P}, \mathrm{K}, \mathrm{Na}, \mathrm{Zn}, \mathrm{Cu}, \mathrm{Mn}$ & {$[263,264]$} \\
\hline Moth bean & 343 & $23-26$ & $1.6(0.4)$ & 61.5 & 5 & $\mathrm{C}, \mathrm{B}_{1}, \mathrm{~B}_{2}, \mathrm{~B}_{3}, \mathrm{~B}_{6}, \mathrm{~B}_{9}, \mathrm{~A}$ & $\mathrm{Ca}, \mathrm{Fe}, \mathrm{Mg}, \mathrm{P}, \mathrm{K}, \mathrm{Na}, \mathrm{Zn}$ & {$[75,224]$} \\
\hline Mung bean & 347 & $15-28$ & $1.2(0.4)$ & 62.6 & 16.3 & $\mathrm{C}, \mathrm{B}_{1}, \mathrm{~B}_{2}, \mathrm{~B}_{3}, \mathrm{~B}_{6}, \mathrm{~B}_{9}, \mathrm{~A}$ & $\mathrm{Ca}, \mathrm{Fe}, \mathrm{Mg}, \mathrm{P}, \mathrm{K}, \mathrm{Na}, \mathrm{Zn}$ & {$[75,224,238,265,266]$} \\
\hline
\end{tabular}




\begin{tabular}{|c|c|c|c|c|c|c|c|c|}
\hline Narbon bean & 271 & 26.9 & $10-15$ & $52-53$ & & & $\mathrm{Ca}, \mathrm{Fe}, \mathrm{Mg}, \mathrm{P}, \mathrm{K}, \mathrm{Zn}, \mathrm{Cu}, \mathrm{Mn}, \mathrm{S}$ & {$[244,267,268]$} \\
\hline Navy bean & 337 & 22.3 & $1.5(0.2)$ & 60.8 & 15.3 & $\mathrm{~B}_{1}, \mathrm{~B}_{2}, \mathrm{~B}_{3}, \mathrm{~B}_{6}, \mathrm{~B}_{9}$ & $\mathrm{Ca}, \mathrm{Fe}, \mathrm{Mg}, \mathrm{P}, \mathrm{K}, \mathrm{Na}, \mathrm{Zn}$ & {$[224,269]$} \\
\hline Pigeon Pea & 343 & $13-26$ & $1.5(0.3)$ & 62.8 & 15 & $\mathrm{~B}_{1}, \mathrm{~B}_{2}, \mathrm{~B}_{3}, \mathrm{~B}_{6}, \mathrm{~B}_{9}, \mathrm{~A}$ & $\mathrm{Ca}, \mathrm{Fe}, \mathrm{Mg}, \mathrm{P}, \mathrm{K}, \mathrm{Na}, \mathrm{Zn}$ & {$[75,224]$} \\
\hline Pinto bean & 347 & 21.4 & $1.2(0.2)$ & 62.6 & 15.5 & $\mathrm{C}, \mathrm{B}_{9}, \mathrm{~K}, \mathrm{E}$ & $\mathrm{Ca}, \mathrm{Fe}, \mathrm{Mg}, \mathrm{P}, \mathrm{K}, \mathrm{Na}, \mathrm{Zn}$ & {$[224,269]$} \\
\hline Pinto Peanut & & 27.1 & $49.7(9.4)$ & 21.4 & & & & [270] \\
\hline Protein pea & 352 & 23.8 & $1.2(0.2)$ & 63.7 & 25 & $\mathrm{C}, \mathrm{B}_{1}, \mathrm{~B}_{2}, \mathrm{~B}_{3}, \mathrm{~B}_{6}, \mathrm{~B}_{9}, \mathrm{~A}, \mathrm{E}, \mathrm{K}$ & $\mathrm{Ca}, \mathrm{Fe}, \mathrm{Mg}, \mathrm{P}, \mathrm{K}, \mathrm{Na}, \mathrm{Zn}$ & [224] \\
\hline Purple mucuna & 417 & 23.9 & $13.3(5.3)$ & 51.7 & 8.1 & $\mathrm{C}, \mathrm{B}_{3}$ & $\mathrm{Ca}, \mathrm{Fe}, \mathrm{Mg}, \mathrm{P}, \mathrm{K}, \mathrm{Na}, \mathrm{Zn}, \mathrm{Cu}, \mathrm{Mn}$ & [271] \\
\hline Red moneywort & 439 & $16-27$ & $14.0(2.8)$ & 54.6 & 4.25 & & $\mathrm{Ca}, \mathrm{Fe}, \mathrm{Mg}, \mathrm{P}, \mathrm{K}, \mathrm{Na}, \mathrm{Zn}, \mathrm{Cu}, \mathrm{Mn}$ & {$[272,273]$} \\
\hline Ricebean & 338 & $18-19$ & $0.5(0.3)$ & 59.1 & 7.1 & $\mathrm{C}, \mathrm{B}_{2}$ & $\mathrm{Ca}, \mathrm{Fe}, \mathrm{P}, \mathrm{Zn}, \mathrm{Cu}, \mathrm{Mn}$ & {$[75,174,224,274]$} \\
\hline Scarlet runner bean & 338 & 20.3 & $1.8(-)$ & 62.0 & 4.8 & $\mathrm{C}, \mathrm{B}_{1}, \mathrm{~B}_{2}, \mathrm{~B}_{3}$ & $\mathrm{Ca}, \mathrm{Fe}, \mathrm{P}$ & [234] \\
\hline Sesban & 459 & $30-40$ & $5-6(1-2)$ & $45-47$ & $11-16$ & & & {$[83,275]$} \\
\hline Sword bean & 361 & $24-30$ & $2.6-9.8(-)$ & $41-59$ & $7-13$ & $\mathrm{C}, \mathrm{B}_{1}, \mathrm{~B}_{2}$ & $\mathrm{Ca}, \mathrm{Fe}, \mathrm{Mg}, \mathrm{P}, \mathrm{K}, \mathrm{Na}, \mathrm{Zn}, \mathrm{Cu}, \mathrm{Pb}, \mathrm{Hg}$ & {$[75,256,276,277]$} \\
\hline Tamarind & 239 & $24-25$ & $8-12.5$ & $10-19$ & $3-4$ & $\mathrm{C}, \mathrm{B}_{1}, \mathrm{~B}_{2}, \mathrm{~B}_{3}$ & $\mathrm{Ca}, \mathrm{Fe}, \mathrm{Mg}, \mathrm{P}, \mathrm{K}, \mathrm{Na}, \mathrm{Zn}, \mathrm{Cu}, \mathrm{Mn}$ & {$[181,278-280]$} \\
\hline Tarwi & 440 & $41-51$ & $14-24(19)$ & 28.2 & 7.1 & & & {$[75,186,281]$} \\
\hline Tepary bean & 353 & $19-24$ & $1.2(-)$ & 67.8 & 4.8 & $\mathrm{~B}_{1}, \mathrm{~B}_{2}, \mathrm{~B}_{3}$ & $\mathrm{Ca}, \mathrm{Fe}, \mathrm{P}, \mathrm{K}, \mathrm{Na}$ & {$[75,234,265,282]$} \\
\hline Urad & 341 & 25.2 & $1.6(0.1)$ & 59.0 & 18.3 & $\mathrm{~B}_{1}, \mathrm{~B}_{2}, \mathrm{~B}_{3}, \mathrm{~B}_{6}, \mathrm{~B}_{9}, \mathrm{~A}$ & $\mathrm{Ca}, \mathrm{Fe}, \mathrm{Mg}, \mathrm{P}, \mathrm{K}, \mathrm{Na}, \mathrm{Zn}$ & [224] \\
\hline Velvet bean & 373 & $20-29$ & $6-7$ & $50-61$ & $9-11$ & & $\mathrm{Ca}, \mathrm{Fe}, \mathrm{Mg}, \mathrm{P}, \mathrm{K}, \mathrm{Na}, \mathrm{Zn}, \mathrm{Cu}, \mathrm{Mn}$ & {$[60,224,283-289]$} \\
\hline Winged bean & 428 & $30-35$ & $16.3(2.3)$ & 41.7 & $11-26$ & $\mathrm{~B}_{1}, \mathrm{~B}_{2}, \mathrm{~B}_{3}, \mathrm{~B}_{6}, \mathrm{~B}_{9}$ & $\mathrm{Ca}, \mathrm{Fe}, \mathrm{Mg}, \mathrm{P}, \mathrm{K}, \mathrm{Na}, \mathrm{Zn}$ & {$[75,224,285]$} \\
\hline Yam bean & 390 & $10-32$ & $24-26$ & $31-33$ & $7-8$ & $\mathrm{C}, \mathrm{B}_{1}, \mathrm{~B}_{2}, \mathrm{~B}_{3}, \mathrm{~B}_{6}$ & $\mathrm{Ca}, \mathrm{Fe}, \mathrm{Mg}, \mathrm{P}, \mathrm{K}, \mathrm{Na}, \mathrm{Zn}, \mathrm{Mn}, \mathrm{Se}$ & {$[71,290,291]$} \\
\hline Broad bean & 341 & 26.1 & $1.53(0.3)$ & 58.3 & 25 & $\mathrm{C}, \mathrm{B}_{1}, \mathrm{~B}_{2}, \mathrm{~B}_{3}, \mathrm{~B}_{6}, \mathrm{~B}_{9}, \mathrm{~A}, \mathrm{E}, \mathrm{K}$ & $\mathrm{Ca}, \mathrm{Fe}, \mathrm{Mg}, \mathrm{P}, \mathrm{K}, \mathrm{Na}, \mathrm{Zn}$ & {$[224,292]$} \\
\hline Chickpea & 378 & $11-31$ & $6.0(0.6)$ & 63.0 & 12.2 & $\mathrm{C}, \mathrm{B}_{1}, \mathrm{~B}_{2}, \mathrm{~B}_{3}, \mathrm{~B}_{6}, \mathrm{~B}_{9}, \mathrm{~A}, \mathrm{E}, \mathrm{K}$ & $\mathrm{Ca}, \mathrm{Fe}, \mathrm{Mg}, \mathrm{P}, \mathrm{K}, \mathrm{Na}, \mathrm{Zn}$ & {$[75,224,293-295]$} \\
\hline Common bean & & $20-24$ & $0.8(0.6)$ & 75.5 & & $\mathrm{~B}_{9}, \mathrm{~A}$ & $\mathrm{Ca}, \mathrm{Fe}, \mathrm{Mg}, \mathrm{K}, \mathrm{P}, \mathrm{Na}, \mathrm{Zn}, \mathrm{Mn}, \mathrm{Se}, \mathrm{S}, \mathrm{B}$ & [296-298] \\
\hline Field pea & 352 & 23.8 & $1.2(0.2)$ & 63.7 & 25 & $\mathrm{C}, \mathrm{B}_{1}, \mathrm{~B}_{2}, \mathrm{~B}_{3}, \mathrm{~B}_{6}, \mathrm{~B}_{9}, \mathrm{~A}, \mathrm{E}, \mathrm{K}$ & $\mathrm{Ca}, \mathrm{Fe}, \mathrm{Mg}, \mathrm{P}, \mathrm{K}, \mathrm{Na}, \mathrm{Zn}$ & [224] \\
\hline Lentil & 352 & 24.6 & $1.1(0.2)$ & 63.4 & 10.7 & $\mathrm{C}, \mathrm{B}_{1}, \mathrm{~B}_{2}, \mathrm{~B}_{3}, \mathrm{~B}_{6}, \mathrm{~B}_{9}, \mathrm{~A}, \mathrm{E}, \mathrm{K}$ & $\mathrm{Ca}, \mathrm{Fe}, \mathrm{Mg}, \mathrm{P}, \mathrm{K}, \mathrm{Na}, \mathrm{Zn}, \mathrm{Se}$ & {$[224,299-301]$} \\
\hline Lupin & 371 & 36.2 & $9.7(1.2)$ & 40.37 & 18.9 & $\mathrm{C}, \mathrm{B}_{1}, \mathrm{~B}_{2}, \mathrm{~B}_{3}, \mathrm{~B}_{6}, \mathrm{~B}_{9}$ & $\mathrm{Ca}, \mathrm{Fe}, \mathrm{Mg}, \mathrm{P}, \mathrm{K}, \mathrm{Na}, \mathrm{Zn}$ & {$[224,302]$} \\
\hline
\end{tabular}

Appendix C: Nutritional composition of grains of non pulses crops

\begin{tabular}{|c|c|c|c|c|c|c|c|c|c|}
\hline $\begin{array}{l}\text { Other crops - } \\
\text { Common name }\end{array}$ & Latin name & $\begin{array}{c}\text { En- } \\
\text { ergy } \\
\text { (Kcal } \\
\text { ) }\end{array}$ & $\begin{array}{l}\text { Pro- } \\
\text { tein } \\
(\%)\end{array}$ & $\begin{array}{c}\text { Oil (satu- } \\
\text { rated FA) } \\
(\%)\end{array}$ & $\begin{array}{l}\text { Carbohy- } \\
\text { drate (\%) }\end{array}$ & $\begin{array}{l}\text { Fiber } \\
(\%)\end{array}$ & Vitamins & Minerals & References \\
\hline African walnut & Tetracarpidium conophorum & & 30.1 & 43.4 & 16.9 & 2.6 & & $\begin{array}{c}\mathrm{Ca}, \mathrm{Fe}, \mathrm{Mg}, \mathrm{K}, \mathrm{Mn}, \mathrm{Ni}, \mathrm{Pb} \\
\mathrm{Na}, \mathrm{Cu}\end{array}$ & {$[303,304]$} \\
\hline Almond & Prunus dulcis & 579 & 21.2 & $49.9(3.8)$ & 21.6 & 12.5 & $\mathrm{~B}_{1}, \mathrm{~B}_{2}, \mathrm{~B}_{3}, \mathrm{~B}_{6}, \mathrm{~B}_{9}, \mathrm{E}$ & $\mathrm{Ca}, \mathrm{Fe}, \mathrm{Mg}, \mathrm{P}, \mathrm{K}, \mathrm{Na}, \mathrm{Zn}$ & [224] \\
\hline Cashew & Anacardium occidentale & 552 & 18.2 & $43.9(7.8)$ & 30.2 & 3.3 & $\mathrm{C}, \mathrm{B}_{1}, \mathrm{~B}_{2}, \mathrm{~B}_{3}, \mathrm{~B}_{6}, \mathrm{~B}_{9}, \mathrm{E}, \mathrm{K}$ & $\mathrm{Ca}, \mathrm{Fe}, \mathrm{Mg}, \mathrm{P}, \mathrm{K}, \mathrm{Na}, \mathrm{Zn}$ & [224] \\
\hline
\end{tabular}




\begin{tabular}{|c|c|c|c|c|c|c|c|c|c|}
\hline Castor bean & Ricinus communis & 579 & 20.2 & 45.0 & & 3.1 & & $\mathrm{Ca}, \mathrm{Fe}, \mathrm{Mg}, \mathrm{P}, \mathrm{K}, \mathrm{Na}, \mathrm{Zn}$ & [229] \\
\hline Chia & Salvia hispanica & 486 & 16.5 & $30.7(3.3)$ & 42.1 & 34.4 & $\mathrm{C}, \mathrm{B}_{1}, \mathrm{~B}_{2}, \mathrm{~B}_{3}, \mathrm{~A}, \mathrm{E}$ & $\mathrm{Ca}, \mathrm{Fe}, \mathrm{Mg}, \mathrm{P}, \mathrm{K}, \mathrm{Na}, \mathrm{Zn}$ & [224] \\
\hline Conophor nut & Tetracarpidium conophorum & 590 & 22.8 & 4902 & & 5.5 & & $\mathrm{Ca}, \mathrm{Fe}, \mathrm{Mg}, \mathrm{P}, \mathrm{K}, \mathrm{Na}, \mathrm{Zn}$ & [229] \\
\hline Cotton & Gossypium hirsutum & & $26-46$ & $30-38$ & & 17.3 & & $\mathrm{Ca}, \mathrm{Mg}, \mathrm{P}, \mathrm{K}, \mathrm{S}$ & [305-307] \\
\hline Cram Cram & Cenchrus Biflorus & 370 & 17.8 & 8.5 & 62.3 & & $\mathrm{~B}_{1}, \mathrm{~B}_{2}, \mathrm{~B}_{3}$ & $\mathrm{Ca}, \mathrm{Fe}, \mathrm{P}$ & [234] \\
\hline Egusi melon & Citrullus colocynthis & 537 & 31.4 & 43.9 & & 6.6 & $\mathrm{~B}_{1}, \mathrm{~B}_{2}, \mathrm{~B}_{3}$ & $\mathrm{Ca}, \mathrm{Fe}, \mathrm{Mg}, \mathrm{P}, \mathrm{K}, \mathrm{Na}, \mathrm{Zn}, \mathrm{S}$ & {$[229,308]$} \\
\hline Flaxseed & Linum usitatissimum & 376 & 24.4 & $30.9(2.9)$ & 0 & 38.6 & $\mathrm{~B}_{1}, \mathrm{~B}_{2}, \mathrm{~B}_{3}, \mathrm{~K}$ & $\mathrm{Ca}, \mathrm{Fe}, \mathrm{Mg}, \mathrm{P}, \mathrm{K}, \mathrm{Na}, \mathrm{Zn}, \mathrm{Mn}$ & [309] \\
\hline Groundnut $^{\mathrm{a}}$ & Arachis hypogea & 570 & 25.1 & 47.6 & 20.9 & 8.7 & $\mathrm{~B}_{1}, \mathrm{~B}_{2}, \mathrm{~B}_{3}, \mathrm{~B}_{6}, \mathrm{~B}_{9}$ & $\mathrm{Ca}, \mathrm{Fe}, \mathrm{Mg}, \mathrm{P}, \mathrm{K}, \mathrm{Na}, \mathrm{Zn}$ & [224] \\
\hline Hazelnut & Corylus avellana & 628 & 15.0 & $60.8(4.4)$ & 19.2 & 11.2 & $\mathrm{C}, \mathrm{B}_{1}, \mathrm{~B}_{2}, \mathrm{~B}_{3}, \mathrm{~B}_{6}, \mathrm{~B}_{9}, \mathrm{~A}, \mathrm{E}, \mathrm{K}$ & $\mathrm{Ca}, \mathrm{Fe}, \mathrm{Mg}, \mathrm{P}, \mathrm{K}, \mathrm{Na}, \mathrm{Zn}$ & [224] \\
\hline Hemp & Cannavis sativa & 553 & 31.6 & $48.8(4.6)$ & 8.7 & 4.0 & $\mathrm{C}, \mathrm{B}_{1}, \mathrm{~B}_{2}, \mathrm{~B}_{3}, \mathrm{~B}_{6}, \mathrm{~B}_{9}, \mathrm{~A}, \mathrm{E}$ & $\mathrm{Ca}, \mathrm{Fe}, \mathrm{Mg}, \mathrm{P}, \mathrm{K}, \mathrm{Na}, \mathrm{Zn}$ & [224] \\
\hline $\begin{array}{c}\text { Kalahari white } \\
\text { bautinia }\end{array}$ & Bautinia Petersiana & 371 & 22.9 & $13.1(3.0)$ & 40.2 & 13.0 & $\mathrm{~B}_{1}, \mathrm{~B}_{2}, \mathrm{~B}_{3}$ & $\mathrm{Ca}, \mathrm{Fe}, \mathrm{P}$ & {$[60]$} \\
\hline Linseed & Linum usitatissimum & 534 & 18.3 & $42.2(3.6)$ & 28.9 & 27.3 & $\begin{array}{c}\mathrm{B}_{1}, \mathrm{~B}_{2}, \mathrm{~B}_{3}, \mathrm{~B}_{5}, \mathrm{~B}_{6}, \mathrm{~B}_{9}, \mathrm{~B}_{12} \\
\mathrm{E}, \mathrm{K}\end{array}$ & $\begin{array}{c}\mathrm{Ca}, \mathrm{Fe}, \mathrm{Ni}, \mathrm{P}, \mathrm{K}, \mathrm{Na}, \mathrm{Zn}, \mathrm{Mn}, \\
\mathrm{Se}, \mathrm{Co}, \mathrm{Cu}, \mathrm{Cr}\end{array}$ & [224] \\
\hline Millet & Pennisetum glaucum & 378 & 11.0 & $4.2(0.7)$ & 72.9 & 8.5 & $\mathrm{~B}_{1}, \mathrm{~B}_{2}, \mathrm{~B}_{3}, \mathrm{~B}_{6}, \mathrm{~B}_{9}, \mathrm{E}, \mathrm{K}$ & $\mathrm{Ca}, \mathrm{Fe}, \mathrm{Mg}, \mathrm{P}, \mathrm{K}, \mathrm{Na}, \mathrm{Zn}$ & [224] \\
\hline Pistachio & Pistacia Vera & 560 & 20.2 & $45.3(5.9)$ & 27.2 & 10.6 & $\mathrm{C}, \mathrm{B}_{1}, \mathrm{~B}_{2}, \mathrm{~B}_{3}, \mathrm{~B}_{6}, \mathrm{~B}_{9}, \mathrm{~A}, \mathrm{E}$ & $\mathrm{Ca}, \mathrm{Fe}, \mathrm{Mg}, \mathrm{P}, \mathrm{K}, \mathrm{Na}, \mathrm{Zn}$ & [224] \\
\hline Quinoa & Chenopodium quinoa & 368 & 14.1 & $6.1(0.7)$ & 64.2 & 7.0 & $\mathrm{~B}_{1}, \mathrm{~B}_{2}, \mathrm{~B}_{3}, \mathrm{~B}_{6}, \mathrm{~B}_{9}, \mathrm{~A}, \mathrm{E}$ & $\mathrm{Ca}, \mathrm{Fe}, \mathrm{Mg}, \mathrm{P}, \mathrm{K}, \mathrm{Na}, \mathrm{Zn}$ & [224] \\
\hline Rapeseed & Brassica napus & & $18-20$ & $43-45$ & & $23-27$ & & & {$[310,311]$} \\
\hline Sesame & Sesamun indicum & 573 & 17.7 & $49.7(7.0)$ & 23.5 & 11.8 & $\mathrm{~B}_{1}, \mathrm{~B}_{2}, \mathrm{~B}_{3}, \mathrm{~B}_{6}, \mathrm{~B}_{9}, \mathrm{~A}, \mathrm{E}$ & $\mathrm{Ca}, \mathrm{Fe}, \mathrm{Mg}, \mathrm{P}, \mathrm{K}, \mathrm{Na}, \mathrm{Zn}$ & [224] \\
\hline Soybean & Glycine Mac Merrill & 446 & 36.5 & $19.9(2.9)$ & 30.2 & 9.3 & $\mathrm{C}, \mathrm{B}_{1}, \mathrm{~B}_{2}, \mathrm{~B}_{3}, \mathrm{~B}_{6}, \mathrm{~B}_{9}, \mathrm{~A}, \mathrm{E}, \mathrm{K}$ & $\mathrm{Ca}, \mathrm{Fe}, \mathrm{Mg}, \mathrm{P}, \mathrm{K}, \mathrm{Na}, \mathrm{Zn}$ & [224] \\
\hline Spirulina (dried) & Arthrospira maxima & 290 & 57.5 & $7.7(2.7)$ & 23.9 & 3.6 & $\mathrm{C}, \mathrm{B}_{1}, \mathrm{~B}_{2}, \mathrm{~B}_{3}, \mathrm{~B}_{6}, \mathrm{~B}_{9}, \mathrm{~A}, \mathrm{E}, \mathrm{K}$ & $\mathrm{Ca}, \mathrm{Fe}, \mathrm{Mg}, \mathrm{P}, \mathrm{K}, \mathrm{Na}, \mathrm{Zn}$ & [224] \\
\hline Sunflower (kernel) & Helianthus annuus & 584 & $18-21$ & $51.0(4.4)$ & 20 & 8.6 & $\mathrm{C}, \mathrm{B}_{1}, \mathrm{~B}_{2}, \mathrm{~B}_{3}, \mathrm{~B}_{6}, \mathrm{~B}_{9}, \mathrm{~A}, \mathrm{E}$ & $\mathrm{Ca}, \mathrm{Fe}, \mathrm{Mg}, \mathrm{P}, \mathrm{K}, \mathrm{Na}, \mathrm{Zn}, \mathrm{Se}$ & [224] \\
\hline Walnut & Juglans spp. & 654 & 15.2 & $65.2(6.1)$ & 13.7 & 6.7 & $\mathrm{C}, \mathrm{B}_{1}, \mathrm{~B}_{2}, \mathrm{~B}_{3}, \mathrm{~B}_{6}, \mathrm{~B}_{9}, \mathrm{~A}, \mathrm{E}, \mathrm{K}$ & $\mathrm{Ca}, \mathrm{Fe}, \mathrm{Mg}, \mathrm{P}, \mathrm{K}, \mathrm{Na}, \mathrm{Zn}$ & [224] \\
\hline
\end{tabular}

a Equivalent to Peanut

Appendix D : Antinutritional constituents of pulses and other crops with high protein content

\begin{tabular}{|c|c|c|c|c|c|c|c|}
\hline $\begin{array}{c}\text { Crops - Common } \\
\text { name }\end{array}$ & $\begin{array}{l}\text { Phytic } \\
\text { acid } \\
(\mathrm{mg} / \mathrm{g})\end{array}$ & $\begin{array}{c}\text { Tannins } \\
\text { total } \\
(\mathrm{mg} / \mathrm{g}) \\
\end{array}$ & $\begin{array}{c}\text { Sapo- } \\
\text { nins } \\
() \\
\end{array}$ & $\begin{array}{l}\text { Trypsin in- } \\
\text { hibitors } \\
(\mathrm{mg} / 100 \mathrm{~g})\end{array}$ & $\begin{array}{l}\text { Lectins } \\
\text { (mg/100g) }\end{array}$ & Others $^{a}$ & References \\
\hline Acacia leucophloea & Presence & 0.01 & & Presence & & & [223] \\
\hline Adzuki bean & & 2.9 & & & & & [312] \\
\hline African locust bean & 0.6 & 0.81 & & 19.4 & & $\mathrm{HCN}$; OX & [227-229] \\
\hline African nut bean & Presence & $0.07-0.3$ & & & & OX & [313] \\
\hline African oil bean & 41 & 7.9 & 17.8 & & & $\mathrm{HCN}$ & {$[99,229]$} \\
\hline African yam bean & 4.3-14.9 & 18.1 & 1.2 & 6.7 & & $\mathrm{HCN}$; OX & {$[79,314]$} \\
\hline
\end{tabular}




\begin{tabular}{|c|c|c|c|c|c|c|c|}
\hline Bambara groundnut & $0.5-14.8$ & $\operatorname{tr}-5.0$ & 1.4 & 6.7 & & OX & {$[235,315-317]$} \\
\hline Butterfly pea & 11.5 & 8.7 & & & & HCN; L-DOPA ${ }^{i}$ & [239] \\
\hline Castor bean & 0.89 & 0.11 & & & & OX; A & [229] \\
\hline Conophor nut & 2.1 & 0.21 & & & & OX & [229] \\
\hline Cotton & & 0.1 & & & & $\mathrm{GO}$ & [306] \\
\hline Cowpea & $1.4-3.8$ & $1.4-10.2$ & 0.3 & $26.4^{b}$ & & $\mathrm{HCN} ; \mathrm{OX}$ & {$[82,315,318,319]$} \\
\hline Egusi melon & 4.1 & 0.8 & & & & OX & [229] \\
\hline Ervil & & Presence & & Presence & & PA & {$[242,244]$} \\
\hline Fenugreek & & & $0.1-0.9$ & & & & {$[247,248]$} \\
\hline Grass pea & 3.0 & $0.2-0.8$ & & $19.64^{b}$ & & $\beta$-ODAP; CTI & {$[249,320-323]$} \\
\hline Groundnut ${ }^{\mathrm{h}}$ & 4.18 & 0.04 & & $80.8^{b}$ & & $\mathrm{OX} ; \mathrm{HCN} ; \mathrm{AL} ; \mathrm{Al}$ & [85] \\
\hline Guanacaste & 9.5 & 3.7 & & & & HCN; L-DOPA & [239] \\
\hline Horse gram & & 2 & & 865 & & & {$[251,253]$} \\
\hline Housa groundnut & Presence & Presence & & & Presence & & [324] \\
\hline Itching bean & $4.7-56.8$ & $1.8-3.3$ & 1.2-1.3 & $43.2-43.7^{b}$ & & $\mathrm{HCN}$ & {$[29,254,315]$} \\
\hline Jack bean & $12.0-13.7$ & Tr-0.7 & 1.8 & $16.4^{b}$ & & $\mathrm{HCN}$; CV; OX & {$[233,315,318,325,326]$} \\
\hline Kedaung & & 98.3 & 0.3 & $6.94^{b}$ & & & {$[81,142]$} \\
\hline Kidney bean & $17.3-24.1$ & $5.4-28.8$ & $0.9-23$ & $4.6-29.3^{b}$ & $1.92-9.98^{\mathrm{c}}$ & $\mathrm{HCN} ; \mathrm{OX}$ & {$[82,327]$} \\
\hline Lablab & $6.1-15.7$ & $0.2-0.4$ & 1.3 & $19.7^{b}$ & & OX & {$[233,261,315,318,326]$} \\
\hline Lima bean & 13.6 & $6.5-9.1$ & $1.2-1.5$ & $2.1-17.2^{\mathrm{b}}$ & & $\mathrm{HCN}$; OX & {$[233,312,315,326]$} \\
\hline Linseed & & & & & & $\mathrm{HCN}$ & [328] \\
\hline Morama bean & & & 0.08 & Presence & & & {$[264,329]$} \\
\hline Moth bean & $3.8-4.2$ & $4.8-13$ & 33 & $28.3-31.4^{\mathrm{b}}$ & & $\mathrm{HCN}$ & {$[82,315]$} \\
\hline Mung bean & $5.8-7.4$ & $4.4-8.0$ & $2.8-35$ & $15.8^{b}$ & $2670^{d}$ & OX & {$[82,84,312,330]$} \\
\hline Narbon bean & & Presence & & Presence & & PA & {$[242,244,331]$} \\
\hline Navy bean & $12.9-15.8$ & 39.9 & $20-160$ & $5.9^{f}$ & $3.8^{c}$ & OX & {$[82,332-334]$} \\
\hline Pigeon Pea & $7.3-16.2$ & $3.8-17.1$ & $0.04-1.4$ & $4.1-19.2^{\mathrm{b}}$ & & HCN; OX; CTI; PA & {$[75,82,233,315,335]$} \\
\hline Pinto bean & & 2.6 & & & $2.3^{\mathrm{c}}$ & OX & {$[82,269,312,334]$} \\
\hline Pinto Peanut & & Presence & & & & & \\
\hline Purple mucuna & $3.8-4.5$ & $1.8-3.4$ & & $39.2-44.1$ & & $\mathrm{HCN}$ & [315] \\
\hline Rapeseed & Presence & Presence & & & & Glucosinolates & [328] \\
\hline Red moneywort & & Presence & & & & & [272] \\
\hline Ricebean & $3.3-20.3$ & 2.4 & 2.3 & $34.3-40.6$ & $\operatorname{Tr}$ & $\mathrm{HCN}$ & {$[174,274,315,336]$} \\
\hline Scarlet runner bean & & & & Presence* $^{*}$ & Presence* $^{*}$ & & {$[337,338]$} \\
\hline Sesban & $18-51$ & 19 & $5.2-14.6$ & $50-140$ & Presence & PA & {$[83,275]$} \\
\hline Sword bean & $3.5-21.4$ & $0.01-570$ & $1.7-5.2$ & $17.4-26.8^{b}$ & & $\mathrm{HCN} ; \mathrm{OX}$ & {$[80,233,315,326,339]$} \\
\hline
\end{tabular}




\begin{tabular}{|c|c|c|c|c|c|c|c|}
\hline Tamarind & Presence & Presence & & Presence & & & {$[182,340]$} \\
\hline Tarwi & & & & $\mathrm{T}$ & & $\mathrm{AL} ; \mathrm{HCN}$ & [186] \\
\hline Tepary bean & & & $1-37$ & $11.5-18.0^{\mathrm{b}}$ & $1.4-18.2^{\mathrm{e}}$ & & [82] \\
\hline Urad & $11.2-14.6$ & $5.4-11.9$ & $0.2-23$ & $94.2^{9}$ & & & {$[82,312,315,341]$} \\
\hline Velvet bean & $5.0-53.6$ & $1.8-3.1$ & & $43.2-52.8$ & & AL; HCN; L-DOPA & {$[29,315,325,342-346]$} \\
\hline Winged bean & $7.8-12.3$ & $0.3-12.6$ & & $0.01-0.14^{\mathrm{e}}$ & $76^{e}$ & CTI & {$[347,348]$} \\
\hline Yam bean & $\operatorname{Tr}$ & $\mathrm{Tr}$ & & 0.01 & 0.0003 & $\mathrm{HCN}$ & [290] \\
\hline Broad bean & 6.4 & $0.1-24.1$ & $0.4-370$ & $1.7-3.3^{b}$ & $25-100^{d}$ & CTI; L-DOPA & {$[82,87,315,349]$} \\
\hline Chickpea & $1.2-12.1$ & $08-5.9$ & $0.09-600$ & $11.9^{\mathrm{b}}$ & $6.22^{d}$ & HCN; OX; PA; CTI & {$[82,315,350][75]$} \\
\hline Common bean & 8.2 & & & $0-4.649$ & 8.57 & $\mathrm{CTI} ; \mathrm{Al}$ & {$[82,298,351]$} \\
\hline Field pea & $2.2-7.4$ & $0.2-13$ & $18-110$ & $1.5-108$ & $5.1-150.6$ & OS; PA; Al; HCN; CTI & {$[82,352]$} \\
\hline Lentil & 2.4-12.4 & 12.8 & $0.04-0.13$ & 2.8 & & OX; Al & {$[353,354]$} \\
\hline Lupin & $1.4-3.5$ & ABS & ABS & ABS & ABS & $\mathrm{PH} ; \mathrm{AL}$ & [355-357] \\
\hline Soybean & $10.0-23.0$ & & $0.2-5.6$ & $0.2-1.12 b$ & & & {$[233,315,358]$} \\
\hline
\end{tabular}

a Presence of: OS: Oligosaccharides; PA; Phenolic acid; Al: Amylase inhibitor; HCN: Hydrogen cyanide ; CV : Canavanine ; OX : Oxalate ; A : Allergens ;

$\mathrm{PH}$ : Phomopsine ; GO : Gossypol ; CTI : Chymotrypsin inhibitors ; GC : $\gamma$-glutamyl- $\beta$-cyanialanine ; VC3 : Vicianine+Vicine+Convincine ; CA : Caravanine ; AL : Alkaloïds ; $\beta$-ODAP (beta-oxalyl-diamino-propionic acid ; TAN : Tannins

b : Units Trypsin Units Inhibited TUl/mg protein; ${ }^{\mathrm{c}}$ : Units $\mathrm{g} / \mathrm{kg} \mathrm{PHA} \mathrm{:} \mathrm{Lectin} \mathrm{as} \mathrm{PHA} \mathrm{(P.} \mathrm{vulgaris} \mathrm{lectin);}{ }^{\mathrm{d}}$ : Units HU/mg sample ; ${ }^{\mathrm{a}}:$ Units HUA/g proteins ;

${ }^{f}$ : Units TIA/g sample; ${ }^{g}$ : Units IU/g seed $;{ }^{\mathrm{h}}$ : data reported in groundnut oil ; ${ }^{\mathrm{i}}$ 1-3,4-dihydroxyphenylalanin; ND: Non Detected;Tr: traces ; ABS : Ab-

sence ; * Presence : Molecules detected but unquantified 


\section{References}

1. de Boer, J.; Aiking, H. On the Merits of Plant-Based Proteins for Global Food Security: Marrying Macro and Micro Perspectives. Ecological Economics 2011, 70, 1259-1265, doi:10.1016/j.ecolecon.2011.03.001.

2. Ranalli, P. Improvement of Pulse Crops in Europe. European Journal of Agronomy 1995, 4, 151-166, doi:10.1016/S1161-0301(14)80042-7.

3. Voisin, A.-S.; Guéguen, J.; Huyghe, C.; Jeuffroy, M.-H.; Magrini, M.-B.; Meynard, J.-M.; Mougel, C.; Pellerin, S.; Pelzer, E. Legumes for Feed, Food, Biomaterials and Bioenergy in Europe: A Review. Agronomy for Sustainable Development 2014, 34, 361-380, doi:10.1007/s13593-013-0189-y.

4. Voisin, A.-S.; Guéguen, J.; Huyghe, C.; Jeuffroy, M.-H.; Magrini, M.-B.; Meynard, J.-M.; Mougel, C.; Pellerin, S.; Pelzer, E. Legumes for Feed, Food, Biomaterials and Bioenergy in Europe: A Review. Agronomy for Sustainable Development 2014, 34, 361-380, doi:10.1007/s13593-013-0189-y.

5. Smýkal, P.; Coyne, C.J.; Ambrose, M.J.; Maxted, N.; Schaefer, H.; Blair, M.W.; Berger, J.; Greene, S.L.; Nelson, M.N.; Besharat, N.; et al. Legume Crops Phylogeny and Genetic Diversity for Science and Breeding. Critical Reviews in Plant Sciences 2015, 34, 43-104, doi:10.1080/07352689.2014.897904.

6. Ayerdi Gotor, A.; Marraccini, E. Crops Providing Proteins for Food: A Review. In ESA14 - Growing landscapes Cultivating innovative agricultural systems; Aspects of Applied Biology; ESA: Edinburgh, Scotland, 2016; p. 5.275.28 .

7. FAOSTAT 2013 Food Supply (Kg/Capita/Year) 2019.

8. $\quad$ Ahlawat, I.; Sharma, P.; Singh, U. Indian Journal of Agronomy. December 1 2016, p. S33_S41.

9. Watson, C.A.; Reckling, M.; Preissel, S.; Bachinger, J.; Bergkvist, G.; Kuhlman, T.; Lindström, K.; Nemecek, T.; Topp, C.F.E.; Vanhatalo, A.; et al. Chapter Four - Grain Legume Production and Use in European Agricultural Systems. In Advances in Agronomy; Sparks, D.L., Ed.; Academic Press, 2017; Vol. 144, pp. $235-303$ ISBN $0065-2113$.

10. Kearney John Food Consumption Trends and Drivers. Philosophical Transactions of the Royal Society B: Biological Sciences 2010, 365, 2793-2807, doi:10.1098/rstb.2010.0149.

11. Schneider, A. Overview of the Market and Consumption of Pulses in Europe. The British journal of nutrition 2003, 88 Suppl 3, S243-50, doi:10.1079/BJN2002713.

12. Desriers, M. L'agriculture française depuis cinquante ans: des petites exploitations familiales aux droits à paiement unique. 2007, 14 .

13. European Commission Development of Plant Proteins in the European Union; Commission to the Council and The European Parliament: Brussels, Belgium, 2018; p. 16 pp.;

14. Wezel, A.; Soboksa, G.; McClelland, S.; Delespesse, F.; Boissau, A. The Blurred Boundaries of Ecological, Sustainable, and Agroecological Intensification: A Review. Agronomy for Sustainable Development 2015, 35, 12831295, doi:10.1007/s13593-015-0333-y.

15. Bowen, C.R.; Hollinger, S.E. Geographic Screening of Potential Alternative Crops. Renewable Agriculture and Food Systems 2004, 19, 141-151, doi:10.1079/RAFS200473.

16. von Richthofen, J.-S.; Pahl, H.; Bouttet, D.; Casta, P.; Cartrysse, C.; Charles, R.; Lafarga, A. What Do European Farmers Think about Grain Legumes? Grain Legumes 2006, 45, 14-15.

17. Zander, P.; Amjath-Babu, T.S.; Preissel, S.; Reckling, M.; Bues, A.; Schläfke, N.; Kuhlman, T.; Bachinger, J.; Uthes, S.; Stoddard, F.; et al. Grain Legume Decline and Potential Recovery in European Agriculture: A Review. Agronomy for Sustainable Development 2016, 36, 26, doi:10.1007/s13593-016-0365-y.

18. Magrini, M.-B.; Anton, M.; Cholez, C.; Corre-Hellou, G.; Duc, G.; Jeuffroy, M.-H.; Meynard, J.-M.; Pelzer, E.; Voisin, A.-S.; Walrand, S. Why Are Grain-Legumes Rarely Present in Cropping Systems despite Their 
Environmental and Nutritional Benefits? Analyzing Lock-in in the French Agrifood System. Ecological Economics 2016, 126, 152-162, doi:10.1016/j.ecolecon.2016.03.024.

19. Reckling, M.; Döring, T.F.; Bergkvist, G.; Stoddard, F.L.; Watson, C.A.; Seddig, S.; Chmielewski, F.-M.; Bachinger, J. Grain Legume Yields Are as Stable as Other Spring Crops in Long-Term Experiments across Northern Europe. Agronomy for Sustainable Development 2018, 38, doi:10.1007/s13593-018-0541-3.

20. Chimonyo, V.G.P.; Snapp, S.S.; Chikowo, R. Grain Legumes Increase Yield Stability in Maize Based Cropping Systems. Crop Science 2019, 59, 1222-1235, doi:10.2135/cropsci2018.09.0532.

21. Mawois, M.; Vidal, A.; Revoyron, E.; Casagrande, M.; Jeuffroy, M.-H.; Le Bail, M. Transition to Legume-Based Farming Systems Requires Stable Outlets, Learning, and Peer-Networking. Agronomy for Sustainable Development 2019, 39, 14, doi:10.1007/s13593-019-0559-1.

22. Chloupek, O.; Hrstkova, P. Adaptation of Crops to Environment. Theoretical and applied genetics 2005, 111, 13161321.

23. Udensi, O.; Umana, E.J.; Edu, E.A.; Ikpeme, E.V. Screening Locally Grown Pulses for Proximate, Anti-Nutritive and Mineral Compositions: Indices for Conservation and Improvement. International journal of agricultural research 2011, 6, 504-510, doi:10.3923/ijar.2011.504.510.

24. Jacobsen, S.-E. The Worldwide Potential for Quinoa (Chenopodium QuinoaWilld.). Food Reviews International 2003, 19, 167-177, doi:10.1081/FRI-120018883.

25. Bazile, D.; Jacobsen, S.-E.; Verniau, A. The Global Expansion of Quinoa: Trends and Limits. Frontiers in Plant Science 2016, 7, 622, doi:10.3389/fpls.2016.00622.

26. Święcicki, W.; Święcicki, W.K.; Wolko, B. Lupinus Anatolicus - A New Lupin Species of the Old World. Genetic Resources and Crop Evolution 1996, 43, 109-117.

27. Spataro, G.; Tiranti, B.; Arcaleni, P.; Bellucci, E.; Attene, G.; Papa, R.; Zeuli, P.S.; Negri, V. Genetic Diversity and Structure of a Worldwide Collection of Phaseolus Coccineus L. Theoretical and Applied Genetics 2011, 122, 12811291, doi:10.1007/s00122-011-1530-y.

28. Srivastava, K.M.; Singh, L.N. A Review of the Pest Complex of Kharif Pulses in Uttar Pradesh. PANS 1976, 22, 333-335, doi:10.1080/09670877609412068.

29. Tresina, P.S.; Mohan, V.R. Assessment of Nutritional and Antinutritional Potential of Underutilized Legumes of the Genus Mucuna. Tropical and Subtropical Agroecosystems 2013, 16, 155-169.

30. Rana, J.C.; Gautam, N.K.; Gayacharan; Singh, M.; Yadav, R.; Tripathi, K.; Yadav, S.K.; Panwar, N.S.; Bhardwaj, R. Genetic Resources of Pulse Crops in India: An Overview. Indian Journal of Genetics and Plant Breeding 2016, 76, 420-436, doi:10.5958/0975-6906.2016.00061.4.

31. Thomson, B.D.; Siddique, K.H.M.; Barr, M.D.; Wilson, J.M. Grain Legume Species in Low Rainfall Mediterranean-Type Environments I. Phenology and Seed Yield. Field Crops Research 1997, 54, 173-187, doi:10.1016/S0378-4290(97)00047-6.

32. Saka, J.O.; Ajibade, S.R.; Adeniyan, O.N.; Olowoyo, R.B.; Ogunbodede, B.A. Survey of Underutilized Grain Legume Production Systems in the Southwest Agricultural Zone of Nigeria. Journal of Agricultural and Food Information 2004, 6, 93-108, doi:10.1300/J108v06n02_08.

33. Azam-Ali, S. Agricultural Diversification: The Potential for Underutilised Crops in Africa's Changing Climates. Rivista di Biologia - Biology Forum 2007, 100, 27-37.

34. Kaoneka, S.R.; Saxena, R.K.; Silim, S.N.; Odeny, D.A.; Ganga Rao, N.V.P.R.; Shimelis, H.A.; Siambi, M.; Varshney, R.K. Pigeonpea Breeding in Eastern and Southern Africa: Plant Breeding 2016, 135, 148-154, doi:10.1111/pbr.12340.

35. Vadivel, V.; Janardhanan, K. Nutritional and Antinutritional Characteristics of Seven South Indian Wild Legumes. Plant Foods for Human Nutrition 2005, 60, 69-75, doi:10.1007/s11130-005-5102-y. 
36. Vadivel, V.; Biesalski, H.K. Bioactive Compounds in Velvet Bean Seeds: Effect of Certain Indigenous Processing Methods. International Journal of Food Properties 2012, 15, 1069-1085, doi:10.1080/10942912.2010.513466.

37. Pullin, A.; Stewart, G. Guidelines for Systematic Review in Environmental Management. Conservation biology : the journal of the Society for Conservation Biology 2007, 20, 1647-1656, doi:10.1111/j.1523-1739.2006.00485.x.

38. Scopus Quick Reference Guide; 2019; p. 12;.

39. Page, M.; McKenzie, J.; Bossuyt, P.; Boutron, I.; Hoffmann, T.; Mulrow, C. The PRISMA 2020 Statement: An Updated Guideline for Reporting Systematic Reviews. BMJ 2021, 372, doi:doi: 10.1136/bmj.n71.

40. Giraldeli, A.L.; San Gregorio, J.P.R.; Monquero, P.A.; Aguillera, M.M.; Ribeiro, N.M. Weeds Hosts of Nematodes in Sugarcane Culture. Planta Daninha 2017, 35, doi:10.1590/S0100-83582017350100029.

41. Correia, M.V.; Pereira, L.C.R.; De Almeida, L.; Williams, R.L.; Freach, J.; Nesbitt, H.; Erskine, W. Maize-Mucuna (Mucuna Pruriens (L.) DC) Relay Intercropping in the Lowland Tropics of Timor-Leste. Field Crops Research 2014, 156, 272-280, doi:10.1016/j.fcr.2013.10.011.

42. Mohamed, H.I.; Abd-El Hameed, A.G. Molecular and Biochemical Markers of Some Vicia Faba L. Genotypes in Response to Storage Insect Pests Infestation. null 2014, 9, 618-626, doi:10.1080/17429145.2013.879678.

43. Oliveira, H.R.; Tomás, D.; Silva, M.; Lopes, S.; Viegas, W.; Veloso, M.M. Genetic Diversity and Population Structure in Vicia Faba L. Landraces and Wild Related Species Assessed by Nuclear SSRs. PLoS ONE 2016, 11, doi:10.1371/journal.pone.0154801.

44. Hanly, J.A.; Gregg, P.E.H. Green-Manure Impacts on Nitrogen Availability to Organic Sweetcorn (Zea Mays). New Zealand Journal of Crop and Horticultural Science 2004, 32, 295-307, doi:10.1080/01140671.2004.9514308.

45. Jayanthi, M.; Umarani, R.; Vijayalakshmi, V. Effect of Seed Fortification with Pulse Sprout Extract on Crop Growth and Seed Yield in Rice Seeds. Asian Journal of Crop Science 2013, 5, 444-451, doi:10.3923/ajcs.2013.444.451.

46. Caracuta, V.; Vardi, J.; Paz, Y.; Boaretto, E. Farming Legumes in the Pre-Pottery Neolithic: New Discoveries from the Site of Ahihud (Israel). PLOS ONE 2017, 12, doi:10.1371/journal.pone.0177859.

47. Lykke, A.M.; Mertz, O.; Ganaba, S. Food Consumption in Rural Burkina Faso. null 2002, 41, 119-153, doi:10.1080/03670240214492.

48. Malau-Aduli, B.; Eduvie, L.; Lakpini, C.; Malau-Aduli, A. Crop-Residue Supplementation of Pregnant Does Influences Birth Weight and Weight Gain of Kids, Daily Milk Yield but Not the Progesterone Profile of Red Sokoto Goats. Reproduction, nutrition, development 2004, 44, 111-121, doi:10.1051/rnd:2004022.

49. Pastor-Cavada, E.; Juan, R.; Pastor, J.E.; Alaiz, M.; Girón-Calle, J.; Vioque, J. Antioxidative Activity in the Seeds of 28 Vicia Species from Southern Spain. Journal of Food Biochemistry 2011, 35, 1373-1380, doi:10.1111/j.17454514.2010.00459.x.

50. Cernay, C.; Pelzer, E.; Makowski, D. A Global Experimental Dataset for Assessing Grain Legume Production. Scientific Data 2016, 3, 160084, doi:10.1038/sdata.2016.84.

51. Tancoigne, E.; Barbier, M.; Cointet, J.-P.; Richard, G. The Place of Agricultural Sciences in the Literature on Ecosystem Services. Ecosystem Services 2014, 10, 35-48, doi:10.1016/j.ecoser.2014.07.004.

52. Ruiz-Martinez, I.; Marraccini, E.; Debolini, M.; Bonari, E. Indicators of Agricultural Intensity and Intensification: A Review of the Literature. Italian Journal of Agronomy 2015, 10, doi:https://doi.org/10.4081/ija.2015.656.

53. Metzger, M.J.; Bunce, R.G.H.; Jongman, R.H.G.; Mücher, C.A.; Watkins, J.W. A Climatic Stratification of the Environment of Europe. Global Ecology and Biogeography 2005, 14, 549-563, doi:10.1111/j.1466-822X.2005.00190.x.

54. Major, D.J.; Brown, D.M.; Bootsma, A.; Dupuis, G.; Fairey, N.A.; GRANT, E.A.; GREEN, D.G.; HAMILTON, R.I.; LANGILLE, J.; SONMOR, L.G.; et al. An Evaluation of the Corn Heat Unit System for the Short-Season Growing Regions across Canada. Can. J. Plant Sci. 1983, 63, 121-130, doi:10.4141/cjps83-012. 
55. Ray, H.; Bett, K.; Tar'an, B.; Vandenberg, A.; Thavarajah, D.; Warkentin, T. Mineral Micronutrient Content of Cultivars of Field Pea, Chickpea, Common Bean, and Lentil Grown in Saskatchewan, Canada. Crop Science 2014, 54, 1698-1708, doi:10.2135/cropsci2013.08.0568.

56. Ribeiro, H.L.C.; Boiteux, L.S.; Santos, C.A.F. Genetic Parameters of Earliness and Plant Architecture Traits Suitable for Mechanical Harvesting of Cowpea (Vigna Unguiculata). Australian Journal of Crop Science 2014, 8, 1232-1238.

57. De Oliveira, J.T.; Ribeiro, I.S.; Roque, C.G.; Montanari, R.; Gava, R.; Teodoro, P.E. Contribution of Morphological Traits for Grain Yield in Common Bean. Bioscience Journal 2018, 34, 951-956.

58. Alliprandini, L.; Abatti, C.; Bertagnolli, P.; Cavassim, J.; Gabe, H.; Kurek, A.; Matsumoto, M.; Oliveira, M.; Pitol, C.; Prado, L.; et al. Understanding Soybean Maturity Groups in Brazil: Environment, Cultivar Classification, and Stability. Crop Science - CROP SCI 2009, 49, doi:10.2135/cropsci2008.07.0390.

59. Jia, H.; Jiang, B.; Wu, C.; Lu, W.; Hou, W.; Sun, S.; Yan, H.; Han, T. Maturity Group Classification and Maturity Locus Genotyping of Early-Maturing Soybean Varieties from High-Latitude Cold Regions. PloS one 2014, 9, e94139, doi:10.1371/journal.pone.0094139.

60. PROTA Céréales et légumes secs; PROTA, 2006; ISBN 978-90-5782-172-1.

61. Appunu, C.; N'Zoue, A.; Moulin, L.; Depret, G.; Laguerre, G. Vigna Mungo, V. Radiata and V. Unguiculata Plants Sampled in Different Agronomical-Ecological-Climatic Regions of India Are Nodulated by Bradyrhizobium Yuanmingense. Syst. Appl. Microbiol. 2009, 32, 460-470, doi:10.1016/j.syapm.2009.05.005.

62. Bouget, M. Les légumineuses vivrières; Le technicien d'agriculture tropicale; Maisonneuve et Larose.; 1989; ISBN 2.7068.0985.X.

63. Sørensen, M.; Heller, J.; Engels, J. Yam Bean. Pachyrhizus DC.; Promoting the conservation and use of underutilized and neglected crops; IPK and IPGRI: Rome, Italy, 1996; Vol. 2; ISBN 978-92-9043-282-1.

64. Klimek-Kopyra, A.; Kulig, B.; Oleksy, A.; Zając, T. Agronomic Performance of Naked Oat (Avena Nuda L.) and Faba Bean Intercropping. Chilean Journal of Agricultural Research 2015, 75, 168-173, doi:10.4067/S071858392015000200005.

65. Akobundu, I.O.; Udensi, U.E.; Chikoye, D. Velvetbean (Mucuna Spp.) Suppresses Speargrass (Imperata Cylindrica (L.) Raeuschel) and Increases Maize Yield. International Journal of Pest Management 2000, 46, 103-108, doi:10.1080/096708700227453.

66. Paulo, E.M.; Berton, R.S.; Cavichioli, J.C.; Bulisani, E.A.; Kasai, F.S. Productivity of Grafted Coffee during Intercropping with Five Leguminous Species in the Western Region of São Paulo State, Brazil. Bragantia 2006, 65, 115-120, doi:10.1590/S0006-87052006000100015.

67. Lusembo, P.; Ebong, C.; Sabiiti, E.N. Integration of Cassava Tuber and Forage Legume Seed Production for Sustained Soil Fertility. Tropical Agriculture 1998, 75, 18-20.

68. Ribeiro, G.M.; Neto, F.B.; De Lima, J.S.S.; Da Silva, M.L.; Barros Júnior, A.P.; Dos Santos, E.C. Productive Performance of Carrot and Cowpea Intercropping System under Different Spatial Arrangements and Population Densities. Revista Caatinga 2018, 31, 19-27.

69. Ocimati, W.; Ntamwira, J.; Groot, J.C.J.; Taulya, G.; Tittonell, P.; Dhed'a, B.; van Asten, P.; Vanlauwe, B.; Ruhigwa, B.; Blomme, G. Banana Leaf Pruning to Facilitate Annual Legume Intercropping as an Intensification Strategy in the East African Highlands. European Journal of Agronomy 2019, 110, doi:10.1016/j.eja.2019.125923.

70. Ameh, G. Proximate and Mineral Composition of Seed and Tuber of African Yam Bean, Sphenostylis Stenocarpa (Hoechst. Ex. A. Rich.) Harms. ASSET Series B 2007, 1-10. 
71. Kisambira, A.; Muyonga, J.H.; Byaruhanga, Y.B.; Tukamuhabwa, P.; Tumwegamire, S.; Grüneberg, W.J. Composition and Functional Properties of Yam Bean (Pachyrhizus Spp.) Seed Flour. Food and Nutrition Sciences 2015, 06, 736, doi:10.4236/fns.2015.68076.

72. Hardarson, G. Methods for Enhancing Symbiotic Nitrogen Fixation. Plant and Soil 1993, 152, 1-17, doi:10.1007/BF00016329.

73. Liu, J.; You, L.; Amini, M.; Obersteiner, M.; Herrero, M.; Zehnder, A.J.B.; Yang, H. A High-Resolution Assessment on Global Nitrogen Flows in Cropland. Proc Natl Acad Sci USA 2010, 107, 8035, doi:10.1073/pnas.0913658107.

74. Bepary, R.H.; Wadikar, D.D.; Patki, P.E. Rice Bean: Nutritional Vibrant Bean of Himalayan Belt (North East India). Nutrition and Food Science 2016, 46, 412-431, doi:10.1108/NFS-08-2015-0097.

75. FAO Utilisation Des Aliments Tropicaux : Légumineuses Tropicales (47/4); Cahiers techniques de la FAO; Food and Agriculture Organization of the United Nations: Rome, Italy, 1990;

76. Spencer, P.F.; Schaumburg, H.H. Lathyrism: A Neurotoxic Disease. Neurobehavioral Toxicology and Teratology 1983, 5, 625-629.

77. Franco, F. Decreto 2484/1967, de 21 de septiembre : Codigo alimentario Español. 1967, 8.

78. Campbell, C.; Mehra, R.; Chen, Y.; Abd El Moneim, A.; Khawaja, H.; Yadov, C.; Tay, J.; Araya, W.; Agrawal, S. Current Status and Future Strategy in Breeding Grasspea (Lathyrus Sativus). Euphytica 1993, 167-175.

79. Ndidi, U.S.; Ndidi, C.U.; Olagunju, A.; Muhammad, A.; Billy, F.G.; Okpe, O. Proximate, Antinutrients and Mineral Composition of Raw and Processed (Boiled and Roasted) Sphenostylis Stenocarpa Seeds from Southern Kaduna, Northwest Nigeria. ISRN Nutrition 2014, 2014, ID 280837, doi:https://doi.org/10.1155/2014/280837.

80. Abigotum, A.S.; Oso, G.K. Assesment of Processing Methods on the Chemical Composition of Sword Bean (Canavalia Gladiata). IOSR Journal of Applied Chemistry 2014, 7, 106-112, doi:10.9790/5736-0752106112.

81. Salam, J.S.; Salam, P.; Potshangbam, K.S.; Kumar, D.B. Effect of Processing Methods on Secondary Metabolites and Enzyme Inhibitors in Different Developmental Stages of Parkia Roxburghii G. Don Pods. American Journal of Food Technology 2014, 89-96, doi:10.3923/ajft.2014.89.96.

82. Campos-Vega, R.; Loarca-Pina, G.; Oomah, B.D. Minor Components of Pulses and Their Potential Impact on Human Health. Food Research International 2010, 43, 461-482, doi:10.1016/j.foodres.2009.09.004.

83. Hossain, M.A.; Becker, K. Nutritive Value and Antinutritional Factors in Different Varieties of Sesbania Seeds and Their Morphological Fractions. Food Chemistry 2001, 73, 421-431, doi:10.1016/S0308-8146(00)00317-4.

84. Kataria, A.; Chauhan, B.M.; Punia, D. Antinutrients and Protein Digestibility (in Vitro) of Mungbean as Affected by Domestic Processing and Cooking. Food Chemistry 1989, 32, 9-17, doi:10.1016/0308-8146(89)90003-4.

85. Inuwa, H.M.; Aina, V.O.; Gabi, B.; Aimola, I.; Toyin, A. Comparative Determination of Antinutritional Factos in Groundnut Oil Ad Palm Oil. 2011, 5.

86. Phillipson, J.D. Natural Toxicants in Feeds and Poisonous Plants. Flavour and Fragrance Journal 1986, 1, 87-87, doi:10.1002/ffj.2730010207.

87. Abd El-Hady, E.A.; Habiba, R.A. Effect of Soaking and Extrusion Conditions on Antinutrients and Protein Digestibility of Legume Seeds. LWT - Food Science and Technology 2003, 36, 285-293, doi:10.1016/S00236438(02)00217-7.

88. World Agroforestry Acacia Leucophloea; World Agroforestry, 2019; p. 5;

89. Lumpkin, T.A.; McClary, D.C. Azuki Bean: Botany, Production and Uses.; CAB International.; Wallingford (UK); ISBN 0-85198-765-6.

90. Haq, N. Underutilized Field Legumes. In Biology and breeding of food legumes; Oxfordshire, UK, 2011 ; pp. 329-347. 
91. Han, L.L.; Wang, E.T.; Lu, Y.L.; Zhang, Y.F.; Sui, X.H.; Chen, W.F.; Chen, W.X. Bradyrhizobium Spp. and Sinorhizobium Fredii Are Predominant in Root Nodules of Vigna Angularis, a Native Legume Crop in the Subtropical Region of China. J. Microbiol. 2009, 47, 287-296, doi:10.1007/s12275-009-0001-5.

92. Singh, J.; Jauhar, P. Genetic Resources Chromosome Engineering, and Crop Improvement; Grain Legumes; Ram J. Singh.; CRC Press (Taylor \& Francis Group),: Boca Raton, Florida, 2005; Vol. 1; ISBN 0-8493-1430-5.

93. Fujihara, S.; Terakado, J.; Takenaka, M.; Yoneyama, T. Specific Occurrence of $\beta$-Phenethylamine in Root Nodules Formed from Bradyrhizobium-Legume Symbiosis. Plant and Soil 2002, 238, 123-132, doi:10.1023/A:1014232305742.

94. Kang, Y.J.; Lee, J.; Kim, Y.H.; Lee, S.-H. Identification of Tissue-Specific Gene Clusters and Orthologues of Nodulation-Related Genes in Vigna Angularis. Plant Genetic Resources: Characterisation and Utilisation 2014, 12, S21-S26, doi:10.1017/S1479262114000185.

95. Kumar, R.; Mittal, R.K.; Pandey, D.P. Genetic Variability for Yield and Growth Attributes in Adzuki Bean. Research on Crops 2012, 13, 562-565.

96. Wang, S.M.; Redden, R.J.; Hu Jiapeng, J.P.; Desborough, P.J.; Lawrence, P.L.; Usher, T. Chinese Adzuki Bean Germplasm: 1. Evaluation of Agronomic Traits. Australian Journal of Agricultural Research 2001, 52, 671-681, doi:10.1071/AR00104.

97. van Oers, C.C.C.M. Vigna Angularis (Willd.) Ohwi \& Ohashi. In Pulses; Plant Resources of South-East Asia; van der Maesen, L.J.G. \& Somaatmadja, S. (Editors): Bogor, Indonesia, 1989.

98. INRA; FAO; CIRAD List of Feeds I Feedipedia Available online: https://www.feedipedia.org/content/feeds?category=13596 (accessed on 26 November 2018).

99. Janick, J.; Paull, R.E. The Encyclopedia of Fruit \& Nuts Available online: http://www.credoreference.com/book/cabifruit.

100. Lewin, A.; Rosenberg, C.; H. Meyer, z. A.; Wong, C.H.; Nelson, L.; Manen, J.-F.; Stanley, J.; Dowling, D.N.; Denarie, J.; Broughton, W.J. Multiple Host-Specificity Loci of the Broad Host-Range Rhizobium Sp. NGR234 Selected Using the Widely Compatible Legume Vigna Unguiculata. Plant Mol Biol 1987, 8, 447-459, doi:10.1007/BF00017990.

101. Bambara Groundnut Vigna Subterranea (L.) Verdc: Proceedings of the Workshop on Conservation and Improvement of Bambara Groundnut (Vigna Subterranea (L.) Verdc.); Heller, J., Begemann, F., Mushonga, J., International Plant Genetic Resources Institute, Zimbabwe, Eds.; Promoting the conservation and use of underutilized and neglected crops; Dept. of Research \& Specialist Services: Rome, Italy : International Plant Genetic Resources Institute ; Causeway, Harare, Zimbabwe, 1997; ISBN 978-92-9043-299-9.

102. Verheye, W.H. Soils, Plant Growth and Crop Production - Volume III; EOLSS Publications, 2010; ISBN 978-1-84826369-7.

103. Alake, C.O.; Ayo-Vaughan, M.A.; Ariyo, J.O. Selection Criteria for Grain Yield and Stability in Bambara Groundnut (Vigna Subterranean (L) Verdc) Landraces. Acta Agriculturae Scandinavica Section B: Soil and Plant Science 2015, 65, 433-447, doi:10.1080/09064710.2015.1020858.

104. Alake, C.O. Genetic Variability, Gains from Selection and Genetic Correlations for Pod Yield and Nutritional Traits in African Landraces of Bambara Groundnut. Biological Agriculture and Horticulture 2018, 34, 71-87, doi:10.1080/01448765.2017.1386128.

105. Berchie, J.N.; Sarkodie-Addo, J.; Adu-Dapaah, H.; Agyemang, A.; Addy, S.; Asare, E.; Donkor, J. Yield Evaluation of Three Early Maturing Bambara Groundnut (Vigna Subterranea L. Verdc) Landraces at the CSIR-Crops Research Institute, Fumesua-Kumasi, Ghana. Journal of Agronomy 2010, 9, 175-179, doi:10.3923/ja.2010.175.179. 
106. Hasan, M.; Uddin, M.K.; Mohamed, M.T.M.; Zuan, A.T.K. Nitrogen and Phosphorus Management for Bambara Groundnut (Vigna Subterranea) Production-A Review. Legume Research 2018, 41, 483-489, doi:10.18805/LR-379.

107. Wassermann, V.D.; Kruger, A.J.; Heyns, G. The Response of Bambara Groundnut (Voandzeia Subterranea) and Pigeon Pea (Cajanus Cajan) to Applications of Lime, p and k. South African Journal of Plant and Soil 1984, 1, 4-8, doi:10.1080/02571862.1984.10634100.

108. Thottappilly, G.; Rossel, H.W. Identification and Characterization of Viruses Infecting Bambara Groundnut (Vigna Subterranea) in Nigeria. International Journal of Pest Management 1997, 43, 177-185, doi:10.1080/096708797228645.

109. Kocabas, Z.; Craigon, J.; Azam-Ali, S.N. The Germination Response of Bambara Groundnut (Vigna Subterranea (L.) Verdc.) to Temperature. Seed Science and Technology 1999, 27, 303-313.

110. Sousa, A.C.B.; Carvalho, M.A.; Ramos, A.K.B.; Campos, T.; Sforça, D.A.; Zucchi, M.I.; Jank, L.; Souza, A.P. Genetic Studies in Centrosema Pubescens Benth, a Tropical Forage Legume: The Mating System, Genetic Variability and Genetic Relationships between Centrosema Species. Euphytica 2011, 181, 223-235, doi:10.1007/s10681-011-0415-0.

111. Odu, C.T.I.; Fayemi, A.A.; Ogunwale, J.A. Effect of PH on the Growth, Nodulation and Nitrogen Fixation of Centrosema Pubescens and Stylosanthes Gracilis. Journal of the Science of Food and Agriculture 1971, 22, 57-59, doi:10.1002/jsfa.2740220203.

112. Keller-Grein, G.; Schultze-Kraft, R.; Franco, L.H.; Ramirez, G. Multilocational Agronomic Evaluation of Selected Centrosema Pubescens Germplasm on Acid Soils. Tropical Grasslands 2000, 34, 65-77.

113. Morris, J.B. Characterization of Butterfly Pea (Clitoria Ternatea L.) Accessions for Morphology, Phenology, Reproduction and Potential Nutraceutical, Pharmaceutical Trait Utilization. Genetic Resources and Crop Evolution 2009, 56, 421-427, doi:10.1007/s10722-008-9376-0.

114. Staples, I.B. Clitoria Ternatea L. In Forages; Plant Resources of South-East Asia; Mannetje, L.'t and Jones, R.M. (Editors): Bogor, Indonesia, 1992.

115. Adjei-Nsiah, S.; Alabi, B.U.; Ahiakpa, J.K.; Kanampiu, F. Response of Grain Legumes to Phosphorus Application in the Guinea Savanna Agro-Ecological Zones of Ghana. Agronomy Journal 2018, 110, 1089-1096, doi:10.2134/agronj2017.11.0667.

116. Pueppke, S.G.; Broughton, W.J. Rhizobiumsp. Strain NGR234 and R. FrediiUSDA257 Share Exceptionally Broad, Nested Host Ranges. Molecular Plant-Microbe Interactions 1999, 12, 293-318, doi:10.1094/MPMI.1999.12.4.293.

117. Abaidoo, R.; Dare, M.O.; Killani, S.; Opoku, A. Evaluation of Early Maturing Cowpea (Vigna Unguiculata) Germplasm for Variation in Phosphorus Use Efficiency and Biological Nitrogen Fixation Potential with Indigenous Rhizobial Populations. Journal of Agricultural Science 2017, 155, 102-116, doi:10.1017/S002185961500115X.

118. Afutu, E.; Agoyi, E.E.; Amayo, R.; Biruma, M.; Rubaihayo, P.R. Cowpea Scab Disease (Sphaceloma Sp.) in Uganda. Crop Protection 2017, 92, 213-220, doi:10.1016/j.cropro.2016.06.024.

119. Ayala-Escobar, V.; Gomez-Jaimes, R.; Santiago-Santiago, V.; Madariaga-Navarrete, A.; Castaneda-Vildozola, A.; Nava-Diaz, C. Pseudocercospora Cruenta on Vigna Unguiculata in Mexico. Australasian Plant Disease Notes 2013, 8, 115-116, doi:10.1007/s13314-013-0110-1.

120. Chaturvedi, G.S.; Aggarwal, P.K.; Sinha, S.K. Growth and Yield of Determinate and Indeterminate Cowpeas in Dryland Agriculture. The Journal of Agricultural Science 1980, 94, 137-144, doi:10.1017/S0021859600027982.

121. Dakora, F.D.; Aboyinga, R.A.; Mahama, Y.; Apaseku, J. Assessment of N2 Fixation in Groundnut (Arachis Hypogaea L.) and Cowpea (Vigna Unguiculata L. Walp) and Their Relative N Contribution to a Succeeding 
Maize Crop in Northern Ghana. Mircen Journal of Applied Microbiology and Biotechnology 1987, 3, 389-399, doi:10.1007/BF00935697.

122. Haruna, I.M.; Usman, A. Agronomic Efficiency of Cowpea Varieties (Vigna Unguiculata L. Walp) under Varying Phosphorus Rates in Lafia, Nasarawa State, Nigeria. Asian Journal of Crop Science 2013, 5, 209-215, doi:10.3923/ajcs.2013.209.215.

123. Wu, X.; Wu, X.; Xu, P.; Wang, B.; Lu, Z.; Li, G. Association Mapping for Fusarium Wilt Resistance in Chinese Asparagus Bean Germplasm. Plant Genome 2015, 8, doi:10.3835/plantgenome2014.11.0082.

124. Tripathi, K.; Gore, P.; Ahlawat, S.; Tyagi, V.; Semwal, D.P.; Gautam, N.; Rana, J.; Kumar, A. Cowpea Genetic Resources and Its Utilization: Indian Perspective - A Review. Legume Research 2019, 42, 439-448, doi:10.18805/LR4146.

125. Russi, L.; Acuti, G.; Trabalza, M.; Porta, R.; Rubini, A.; Damiani, F.; Cristiani, S.; Bosco, A.; Martuscelli, G.; Bellucci, M.; et al. Genetic Characterisation and Agronomic and Nutritional Value of Bitter Vetch (Vicia Ervilia), an under-Utilised Species Suitable for Low-Input Farming Systems. Crop and Pasture Science 2019, doi:10.1071/CP19079.

126. Berger, J.D.; Robertson, L.D.; Cocks, P.S. Agricultural Potential of Mediterranean Grain and Forage Legumes: Key Differences between and within Vicia Species in Terms of Phenology, Yield, and Agronomy Give Insight into Plant Adaptation to Semi-Arid Environments. Genetic Resources and Crop Evolution 2002, 49, 313-325, doi:10.1023/A:1015544126185.

127. Siddique, K.H.M.; Loss, S.P.; Regan, K.L.; Jettner, R.L. Adaptation and Seed Yield of Cool Season Grain Legumes in Mediterranean Environments of South-Western Australia. Australian Journal of Agricultural Research 1999, 50, 375-387, doi:10.1071/A98096.

128. Larbi, A.; Abd El-Moneim, A.M.; Nakkoul, H.; Jammal, B.; Hassan, S. Intra-Species Variations in Yield and Quality Determinants in Vicia Species: 1. Bitter Vetch (Vicia Ervilia L.). Animal Feed Science and Technology 2011, 165, 278-287, doi:10.1016/j.anifeedsci.2010.09.004.

129. Saoub, H.M.; Akash, M.W. Variations among Two Vetch Landrace Species in Jordan. Journal of Food, Agriculture and Environment 2012, 10, 763-767.

130. Government of Saskatchewan Inoculation of Pulse Crops | Soils, Fertility, and Nutrients Available online: https://www.saskatchewan.ca/business/agriculture-natural-resources-and-industry/agribusiness-farmers-andranchers/crops-and-irrigation/soils-fertility-and-nutrients/inoculation-of-pulse-crops (accessed on 29 November 2018).

131. Moradi kor, N.; Didarshetaban, M.B.; Saeid Pour, H.R. Fenugreek (Trigonella Foenum-Graecum L.) as a Valuable Medicinal Plant. International Journal of Advanced Biological and Biomedical Research 2013, 1, $922-931$.

132. Baldoni, R.; Giardini, L. Coltivazioni Erbacee Cereali e Proteaginose; Patron Editore.; 2001; ISBN 978-88-555-2541-1.

133. Vaz Patto, M.C.; Rubiales, D. Resistance to Rust and Powdery Mildew in Lathyrus Crops. Czech Journal of Genetics and Plant Breeding 2014, 50, 116-122.

134. Niembro Rocas, A. Enterolobium Cyclocarpum (Jacq.) Griseb.. In Tropical Tree Seed Manual; Agricultural Handbook; Vozzo, J.A. (ed.): Washington DC. (USA), 2002; pp. 449-451.

135. Krishna, K.R. Agroecosystems of South India Nutrient Dynamics, Ecology and Productivity; BrownWalker Press.; Boca Raton, FL (USA), 2010; ISBN 1-59942-533-5.

136. Jansen, P.C.M. Macrotyloma Uniflorum (Lam.) Verdc. In Pulses; Plant Resources of South-East Asia; van der Maesen, L.J.G. \& Somaatmadja, S. (Editors): Bogor, Indonesia, 1989. 
137. Mohammed, M.; Sowley, E.N.K.; Dakora, F.D. Variations in N2 Fixation of Field-Grown Kersting's Groundnut (Macrotyloma Geocarpum) Landraces in Response to Inoculation with Two Bradyrhizobium Strains in the Northern Region of Ghana. South African Journal of Botany 2016, 103, 333, doi:10.1016/j.sajb.2016.02.112.

138. PROTA4U Macrotyloma Geocarpum (Harms) Marechal Available online: https://www.prota4u.org/database/protav8.asp?fr=1\&g=pe\&p=Macrotyloma+geocarpum+(Harms)+Mar\%E9ch al+\&+Baudet (accessed on 29 November 2018).

139. Université de Liège Fiche technique du mucuna. 2014, 1.

140. Sheahan, C. Plant Guide for Jack Bean (Canavalia Ensiformis). USDA-Natural Resources Conservation Service 2012, 4.

141. Miamoto, A.; Dias-Arieira, C.R.; Cardoso, M.R.; Puerari, H.H. Penetration and Reproduction of Meloidogyne Javanica on Leguminous Crops. Journal of Phytopathology 2016, 164, 890-895, doi:10.1111/jph.12508.

142. Roy, S.S.; Kumar, S.; Sharma, S.; Devi, A.; Singh, N.; Prakash, N.; Ngachan, S. Tree Bean (Parkia Roxburghii): A Potential Multipurpose Tree Legume of North East India. In Proceedings of the Souvenir \& Abstracts; Varanasi, India, February 12 2016; pp. 201-208.

143. Long, R.; Temple, S.; Schmierer, J.; Canevari, M.; Meyer, R.D. Common Dry Bean Production in California, Second Edition; University of California, Agriculture and Natural Resources, 2010; ISBN 978-1-60107-681-6.

144. Bulyaba, R.; Lenssen, A.W. Influence of Bradyrhizobium Inoculation and Fungicide Seed Treatment on Development and Yield of Cowpea, Lablab, and Soybean. Crop, Forage and Turfgrass Management 2017, 3, doi:10.2134/cftm2017.02.0007.

145. Díaz, M.F.; González, A.; Padilla, C.; Curbelo, F. Performance of Forage and Grain Production of Canavalia Ensiformis, Lablab Purpureus and Stizolobium Niveum Plantations Sown in September. Cuban Journal of Agricultural Science 2003, 37, 65-71.

146. Rangaiah, D.V.; Dsouza, M. Hyacinth Bean (Lablab Purpureus): An Adept Adaptor to Adverse Environments. Legume Prespectives 2016, 13, 20.

147. Long, R.; Temple, S.; Meyer, R.; Schwankl, L.; Godfrey, L.; Canevari, M.; Roberts, P. Lima Bean Production in California; University of California, Agriculture and Natural Resources, 2014; ISBN 978-1-60107-860-5.

148. de Araújo, A.S.F.; Antunes, J.E.L.; de Almeida Lopes, A.C.; Ferreira Gomes, R.L. Rhizobia and Lima Bean Symbiosis: Importance, Occurrence, and Diversity Available online: https://www.researchgate.net/publication/297766907_Rhizobia_and_lima_bean_symbiosis_Importance_occurr enceand_diversity (accessed on 27 November 2018).

149. Marsh, L.E.; Davis, D.W. Influence of High Temperature on the Performance of Some Phaseolus Species at Different Developmental Stages. Euphytica 1985, 34, 431-439, doi:10.1007/BF00022939.

150. Mohammed, M.; Sowley, E.N.K.; Dakora, F.D. Variations in N2 Fixation of Field-Grown Kersting's Groundnut (Macrotyloma Geocarpum) Landraces in Response to Inoculation with Two Bradyrhizobium Strains in the Northern Region of Ghana. South African Journal of Botany 2016, 103, 333, doi:10.1016/j.sajb.2016.02.112.

151. Brink, M.; Belay, G. Plant Resources of Tropical Africa 1. Cereals Ans Pulses.; PROTA Foundation, Wageningen, Netherlands/Backhuys Publishers, Leiden, Netherlands/CTA, Wageningen, Netherlands., 2006; ISBN 978-905782-170-7.

152. Pooniya, V.; Choudhary, A.K.; Dass, A.; Bana, R.S.; Rana, K.S.; Rana, D.S.; Tyagi, V.K.; Puniya, M.M. Improved Crop Management Practices for Sustainable Pulse Production: An Indian Perspective. Indian Journal of Agricultural Sciences 2015, 85, 747-758.

153. van Oers, C.C.C.M. Vigna Aconitifolia (Jacq.) Maréchal. In Pulses; Plant Resources of South-East Asia; an der Maesen, L.J.G. \& Somaatmadja, S. (Editors): Bogor, Indonesia, 1989. 
154. Riaz Malik, S.; Imran, M.; Asadullah, M.; Jawad, M.; Sarwar, A. Pulses Program Available online: http://www.parc.gov.pk/index.php/en/csi/137-narc/crop-sciences-institue/712-national-coordinated-pulsesprogramme (accessed on 29 November 2018).

155. Tariq, S.; Ali, S.; Ijaz, S.S. IMPROVING NITROGEN FIXATION CAPACITY AND YIELD OF MUNGBEAN AND MASHBEAN BY PHOSPHOROUS MANAGEMENT IN POTHOWAR. 2007, 23, 6.

156. Chinnasamy, G.; Bal, A.; McKenzie, D. Fatty Acid Composition of Grass Pea (Lathyrus Sativus L.) Seeds. 2005. Lathyrus Lathyrism Newsletter 2005, 1-4.

157. Akhter, M.S.; Akanda, A.M.; Kobayashi, K.; Jain, R.K.; Mandal, B. Plant Virus Diseases and Their Management in Bangladesh. Crop Protection 2019, 118, 57-65, doi:10.1016/j.cropro.2018.11.023.

158. HARDWICK, R.C. Review of Recent Research on Navy Beans (Phaseolus Vulgaris) in the United Kingdom. Annals of Applied Biology 1988, 113, 205-227, doi:10.1111/j.1744-7348.1988.tb03297.x.

159. Gonzalez, D.; Obrador, A.; Alvarez, J.M. Behavior of Zinc from Six Organic Fertilizers Applied to a Navy Bean Crop Grown in a Calcareous Soil. Journal of Agricultural and Food Chemistry 2007, 55, 7084-7092, doi:10.1021/jf071090v.

160. Thomson, B.D.; Siddique, K.H.M.; Barr, M.D.; Wilson, J.M. Grain Legume Species in Low Rainfall Mediterranean-Type Environments I. Phenology and Seed Yield. Field Crops Research 1997, 54, 173-187, doi:10.1016/S0378-4290(97)00047-6.

161. Siddique, K.; Loss, S.; Enneking, D. Narbon Bean (Vicia Narbonensis L.): A Promising Grain Legume for Low Rainfall Areas of South-Western Australia. Australian Journal of Experimental Agriculture 1996, 36, 53-62, doi:10.1071/EA9960053.

162. Nadal, S.; Moreno, M.T. Behaviour of Narbon Bean (Vicia Narbonensis L.) under Presence-Absence of Broomrape (Orobanche Crenata Forsk.) in Rainfed Agricultural Systems in Southern Spain. Journal of Sustainable Agriculture 2007, 30, 133-143, doi:10.1300/J064v30n04_10.

163. Enneking, D.; Maxted, N. Narbon Bean (Vicia Narbonensis L.). In; 1994.

164. Kumar Rao, J.V.D.K.; Dart, P.J. Nodulation, Nitrogen Fixation and Nitrogen Uptake in Pigeonpea (Cajanus Cajan (L.) Millsp) of Different Maturity Groups. Plant Soil 1987, 99, 255-266, doi:10.1007/BF02370872.

165. Smartt, J. Evolution of Grain Legumes. II. Old And New World Pulses of Lesser Economic Importance. Experimental Agriculture 1985, 21, 1-18, doi:10.1017/S0014479700012205.

166. Ahlawat, I.P.S.; Gangaiah, B.; Singh, I.P. Pigeonpea (Cajanus Cajan) Research in India - An Overview. Indian Journal of Agricultural Sciences 2005, 75, 309-320.

167. Osorno, J.M.; Vander Wal, A.J.; Kloberdanz, M.; Pasche, J.S.; Schroder, S.; Miklas, P.N. A New Slow-Darkening Pinto Bean with Improved Agronomic Performance: Registration of 'ND-Palomino.' Journal of Plant Registrations 2018, 12, 25-30, doi:10.3198/jpr2017.05.0026crc.

168. Osorno, J.M.; Grafton, K.F.; Rojas-Cifuentes, G.A.; Gelin, R.; Vander Wal, A.J. Registration of "Lariat” and “Stampede" Pinto Beans. Journal of Plant Registrations 2010, 4, 5-11, doi:10.3198/jpr2009.03.0143crc.

169. Adjolohoun, S.; Bindelle, J.; Adandedjan, C.C.; Tolebq, S.S.; Houinato, M.R., uald; Sinsin, A.B. Variety and Environmental Effects on Crude Protein Concentration and Mineral Composition of Arachis Pintoi (Kaprovickas \& Gregory) in Benin (West Africa). Journal of Applied Biologie E Biotechnologie 2013, 1, 24-28, doi:10.7324/JABB.2013.1304.

170. Heuzé, V.; Tran, G.; Delagarde, R.; Bastianelli, D.; Lebas, F. Pinto Peanut (Arachis Pintoi).; INRA, CIRAD, AFZ and FAO, 2016;

171. Cook, B.G. Arachis Pintoi Krap. \& Greg., Nom. Nud. In Forages; Plant Resources of South-East Asia; Mannetje, L.'t and Jones, R.M. (Editors): Bogor, Indonesia, 1992. 
172. Doignon-Bourcier, F.; Sy, A.; Willems, A.; Torck, U.; Dreyfus, B.; Gillis, M.; de Lajudie, P. Diversity of Bradyrhizobia from 27 Tropical Leguminosae Species Native of Senegal. Systematic and Applied Microbiology 1999, 22, 647-661, doi:10.1016/S0723-2020(99)80018-6.

173. Khadka, K.; Acharya, B.D. Cultivation Practices of Ricebean. 2009.

174. Dhillon, P.K.; Tanwar, B. Rice Bean: A Healthy and Cost-Effective Alternative for Crop and Food Diversity. Food Security 2018, 10, 525-535, doi:10.1007/s12571-018-0803-6.

175. Kapoor, C.; Gopi, R.; Karuppaiyan, R. Ricebean: An Underutilized Pulse Crop of Sikkim. Asian Agri-History 2012, $16,417-421$.

176. Pattanayak, A.; Roy, S.; Sood, S.; Iangrai, B.; Banerjee, A.; Gupta, S.; Joshi, D.C. Rice Bean: A Lesser Known Pulse with Well-Recognized Potential. Planta 2019, 250, 873-890, doi:10.1007/s00425-019-03196-1.

177. Kimani, P.M.; Njau, S.; Mulanya, M.; Narla, R.D. Breeding Runner Bean for Short-Day Adaptation, Grain Yield, and Disease Resistance in Eastern Africa. Food and Energy Security 2019, 8, doi:10.1002/fes3.171.

178. Sileshi, G.; Maghembe, J.A.; Rao, M.R.; Ogol, C.K.P.O.; Sithanantham, S. Insects Feeding on Sesbania Species in Natural Stands and Agroforestry Systems in Southern Malawi. Agroforestry Systems 2000, 49, 41-52, doi:10.1023/A:1006378713271.

179. Sileshi, G.; Mafongoya, P.L. Incidence of Mesoplatys Ochroptera Stål (Coleoptera: Chrysomelidae) on Sesbania Sesban in Pure and Mixed Species Fallows in Eastern Zambia. Agroforestry Systems 2002, 56, 225-231, doi:10.1023/A:1021383430441.

180. Heering, J.H.; Guteridge, R.C. Sesbania Sesban (L.) Merrill. In Forages; Plant Resources of South-East Asia; Mannetje, L.'t and Jones, R.M. (Editors): Bogor, Indonesia, 1992.

181. Yusuf, A.; M. Mofio, B.; Ahmed, A.-B. Proximate and Mineral Composition of Tamarindus Indica Linn 1753 Seeds. Science World Journal 2007, 2, 1-4, doi:10.4314/swj.v2i1.51699.

182. El-Siddig, K.; Gunasena, H.P.M.; Prasad, B.A.; Pushpakumara, D.K.N.G.; Ramana, K.V.R.; Vijayanand, P.; Williams, J.T. Tamarind: Tamarindus Indica L..; Fruits for the Future 1; Southampton Centre for Underutilised Crops.; J.T. Williams (Chief editor) R.W. Smith N. Haq Z. Dunsiger: Southampton, UK, 2006;

183. Bowe, C.; Haq, N. Quantifying the Global Environmental Niche of an Underutilised Tropical Fruit Tree (Tamarindus Indica) Using Herbarium Records. Agriculture, Ecosystems and Environment 2010, 139, 51-58, doi:10.1016/j.agee.2010.06.016.

184. Cardet, C.; Kandji, T.; Delobel, A.; Danthu, P. Efficiency of Neem and Groundnut Oils in Protecting Leguminous Tree Seeds against Seed Beetles in the Sahel. Agroforestry Systems 1998, 40, 29-40, doi:10.1023/A:1006092531845.

185. Castellano, G.; Lugo, Z.; Casassa-Padrón, A.M.; Pérez-Pérez, E.; Núñez-Castellano, K. Plant Parasitic Nematodes Associated to Potentials Fruit Trees, in Three Areas of Mara, Zulia State, Venezuela. Revista de la Facultad de Agronomia 2014, 31, 414-422.

186. Urrutia Gutierrez, W. Determinacion de Parametros Optimos de Extraccion Alcalina Para La Obtencion de Aislado Proteixo a Partir de Tarwi ( Lupinus Mutabilis). 2010.

187. Mogotsi, K.K. Phaseolus Acutifolius Available online: https://www.prota4u.org/database/protav8.asp?fr=1\&g=pe\&p=Phaseolus+acutifolius+A.Gray (accessed on 28 November 2018).

188. Mishra, S.K.; Macedo, M.L.R.; Panda, S.K.; Panigrahi, J. Bruchid Pest Management in Pulses: Past Practices, Present Status and Use of Modern Breeding Tools for Development of Resistant Varieties. Annals of Applied Biology 2018, 172, 4-19, doi:10.1111/aab.12401. 
189. Aeron, A.; Maheshwari, D.K.; Dheeman, S.; Agarwal, M.; Dubey, R.C.; Bajpai, V.K. Plant Growth Promotion and Suppression of Charcoal-Rot Fungus (Macrophomina Phaseolina) in Velvet Bean (Mucuna Pruriens L.) by Root Nodule Bacteria. Journal of Phytopathology 2017, 165, 463-478, doi:10.1111/jph.12581.

190. Arora, N.K.; Kang, S.C.; Maheshwari, D.K. Isolation of Siderophore-Producing Strains of Rhizobium Meliloti and Their Biocontrol Potential against Macrophomina Phaseolina That Causes Charcoal Rot of Groundnut. Current Science 2001, 81, 673-677.

191. Baiswar, P.; Mohapatra, K.P.; Chandra, P.; Ngachan, S.V. Rust Resistance in Mucuna Pruriens Accessions. Indian Phytopathology 2017, 70, 498-499, doi:10.24838/ip.2017.v70.i4.76999.

192. Wulijarni-Soetjipto, N.; Maligalig, R.F. Mucuna Pruriens (L.) DC. Cv. Group Utilis. In Auxiliary plants; Plant Resources of South-East Asia; Faridah Hanum, I \& van der Maesen, L.J.G. (Editors): Bogor, Indonesia, 1997.

193. Okito, A.; Alves, B.J.R.; Urquiaga, S.; Boddey, R.M. Nitrogen Fixation by Groundnut and Velvet Bean and Residual Benefit to a Subsequent Maize Crop. Pesquisa Agropecuaria Brasileira 2004, 39, 1183-1190.

194. National Academies The Winged Bean. A High Protein Crop for the Tropics. Report of an Ad Hoc Panel of the Advisory Committee on Technology Innovation Borad on Science and Technology dor International Development 1975.

195. Sfrensen, M.; van Hoof, W.C.H. Pachyrhizus Erosus (L.) Urban. In Plants yielding non-seed carbohydrates; Plant Resources of South-East Asia; Flach, M. \& Rumawas, F. (Editors): Bogor, Indonesia, 1996.

196. Susan John, K.; George, J.; Shanida Beegum, S.U.; Shivay, Y.S. Soil Fertility and Nutrient Management in Tropical Tuber Crops - An Overview. Indian Journal of Agronomy 2016, 61, 263-273.

197. Unkovich, M.J.; Pate, J.S.; Armstrong, E.L.; Sanford, P. Nitrogen Economy of Annual Crop and Pasture Legumes in Southwest Australia. Soil Biology and Biochemistry 1995, 27, 585-588, doi:10.1016/0038-0717(95)98635-2.

198. Temesgen, T.; Keneni, G.; Sefera, T.; Jarso, M. Yield Stability and Relationships among Stability Parameters in Faba Bean (Vicia Faba L.) Genotypes. Crop Journal 2015, 3, 258-268, doi:10.1016/j.cj.2015.03.004.

199. Ahmed, K.; Awan, M.S. Integrated Management of Insect Pests of Chickpea Cicer Arietinum (L. Walp) in South Asian Countries: Present Status and Future Strategies - A Review. Pakistan Journal of Zoology 2013, 45, 1125-1145.

200. Tiwari, K.N.; Dwivedi, B.S.; Pathak, A.N. Evaluation of Iron Pyrites as Sulphur Fertilizer. Fertilizer Research 1984, 5, 235-243, doi:10.1007/BF01051622.

201. Thangwana, N.M.; Ogola, J.B.O. Yield and Yield Components of Chickpea (Cicer Arietinum): Response to Genotype and Planting Density in Summer and Winter Sowings. Journal of Food, Agriculture and Environment 2012, 10, 710-715.

202. Maqbool, A.; Shafiq, S.; Lake, L. Radiant Frost Tolerance in Pulse Crops-a Review. Euphytica 2010, 172, 1-12, doi:10.1007/s10681-009-0031-4.

203. Mola, T.; Alemayehu, S.; Fikre, A.; Ojiewo, C.; Alemu, K.; Abdi, T. Heat Tolerance Responses of Chickpea (Cicer Arietinum L.) Genotypes in the Thermal Zone of Ethiopia, a Case of Werer Station. 2018, 6.

204. Mukoko, O.Z.; Galwey, N.W.; Allen, D.J. Developing Cultivars of the Common Bean (Phaseolus Vulgaris L.) for Southern Africa: Bean Common Mosaic Virus Resistance, Consumer Preferences and Agronomic Requirements. Field Crops Research 1995, 40, 165-177, doi:10.1016/0378-4290(94)00101-H.

205. Tigist, S.G.; Melis, R.; Sibiya, J.; Keneni, G. Evaluation of Different Ethiopian Common Bean, Phaseolus Vulgaris (Fabaceae) Genotypes for Host Resistance to the Mexican Bean Weevil, Zabrotes Subfasciatus (Coleoptera: Bruchidae). International Journal of Tropical Insect Science 2018, 38, 1-15, doi:10.1017/S1742758417000248.

206. Tigist, S.G.; Melis, R.; Sibiya, J.; Amelework, A.B.; Keneni, G.; Tegene, A. Population Structure and GenomeWide Association Analysis of Bruchid Resistance in Ethiopian Common Bean Genotypes. Crop Science 2019, 59, 1504-1515, doi:10.2135/cropsci2018.09.0559. 
207. Swegarden, H.R.; Sheaffer, C.C.; Michaels, T.E. Yield Stability of Heirloom Dry Bean (Phaseolus Vulgaris L.) Cultivars in Midwest Organic Production. HortScience 2016, 51, 8-14.

208. Soratto, R.P.; Perez, A.A.G.; Fernandes, A.M. Age of No-till System and Nitrogen Management on Common Bean Nutrition and Yield. Agronomy Journal 2014, 106, 809-820, doi:10.2134/agronj13.0439.

209. Maingi, J.M.; Shisanya, C.A.; Gitonga, N.M.; Hornetz, B. Nitrogen Fixation by Common Bean (Phaseolus Vulgaris L.) in Pure and Mixed Stands in Semi-Arid South-East Kenya. European Journal of Agronomy 2001, 14, 112, doi:10.1016/S1161-0301(00)00080-0.

210. Hungria, M.; Campo, R.J.; Mendes, I.C. Benefits of Inoculation of the Common Bean (Phaseolus Vulgaris) Crop with Efficient and Competitive Rhizobium Tropici Strains. Biology and Fertility of Soils 2003, 39, 88-93, doi:10.1007/s00374-003-0682-6.

211. Hernandez-Armenta, R.; Wien, H.C.; Eaglesham, A.R.J. Carbohydrate Partitioning and Nodule Function in Common Bean after Heat Stress. Crop Science 1989, 29, 1292-1297, doi:10.2135/cropsci1989.0011183X002900050041x.

212. Hernández, G.; Ramírez, M.; Valdés-López, O.; Tesfaye, M.; Graham, M.A.; Czechowski, T.; Schlereth, A.; Wandrey, M.; Erban, A.; Cheung, F.; et al. Phosphorus Stress in Common Bean: Root Transcript and Metabolic Responses. Plant Physiology 2007, 144, 752-767, doi:10.1104/pp.107.096958.

213. Gutíerrez, A.P.; Mariot, E.J.; Cure, J.R.; Riddle, C.S.W.; Ellis, C.K.; Villacorta, A.M. A Model of Bean (Phaseolus Vulgaris L.) Growth Types I-III: Factors Affecting Yield. Agricultural Systems 1994, 44, 35-63, doi:10.1016/0308521X(94)90014-7.

214. Graham, P.H.; Ranalli, P. Common Bean (Phaseolus Vulgaris L.). Field Crops Research 1997, 53, 131-146, doi:10.1016/S0378-4290(97)00112-3.

215. Głowacka, A.; Gruszecki, T.; Szostak, B.; Michałek, S. The Response of Common Bean to Sulphur and Molybdenum Fertilization. International Journal of Agronomy 2019, 2019, doi:10.1155/2019/3830712.

216. Tedford, E.C.; Inglis, D.A. Evaluation of Legumes Common to the Pacific Northwest as Hosts for the Pea Cyst Nematode, Heterodera Goettingiana. Journal of Nematology 1999, 31, 155-163.

217. Khan, Z.; Gautam, N.K.; Gawade, B.H.; Dubey, S.C. Screening of Lentil (Lens Culinaris Medik.) Germplasm for Resistance to Root-Knot Nematode, Meloidogyne Incognita. Indian Journal of Genetics and Plant Breeding 2017, 77, 408-413, doi:10.5958/0975-6906.2017.00055.4.

218. Huang, J.; Keshavarz Afshar, R.; Chen, C. Lentil Response to Nitrogen Application and Rhizobia Inoculation. Communications in Soil Science and Plant Analysis 2016, 47, 2458-2464, doi:10.1080/00103624.2016.1254786.

219. Clark, S. Plant Guide for White Lupine (Lupinus Albus L.) 2014.

220. Wylie, S.; Wilson, C.R.; Jones, R.A.C.; Jones, M.G.K. A Polymerase Chain Reaction Assay for Cucumber Mosaic Virus in Lupin Seeds. Australian Journal of Agricultural Research 1993, 44, 41-51, doi:10.1071/AR9930041.

221. Unkovich, M.J.; Pate, J.S.; Hamblin, J. The Nitrogen Economy of Broadacre Lupin in Southwest Australia. Australian Journal of Agricultural Research 1994, 45, 149-164, doi:10.1071/AR9940149.

222. Tang, C.; Zheng, S.J.; Qiao, Y.F.; Wang, G.H.; Han, X.Z. Interactions between High PH and Iron Supply on Nodulation and Iron Nutrition of Lupinus Albus L. Genotypes Differing in Sensitivity to Iron Deficiency. Plant and Soil 2006, 279, 153-162, doi:10.1007/s11104-005-0616-1.

223. Vijayakumari, K.; Siddhuraju, P.; Janardhanan, K. Nutritional Assessment and Chemical Composition of the Lesser Known Tree Legume, Acacia Leucophloea (Roxb.) Willd. Food Chemistry 1994, 50, 285-288, doi:10.1016/0308-8146(94)90134-1.

224. USDA National Nutrient Database for Standard Reference Release 28 Available online: https://ndb.nal.usda.gov/ndb/ (accessed on 17 December 2018). 
225. Yoshida, K.; Sato, H.; Sato, M. The Extent and Its Source of Variation for Characteristics Related to Seed Quality of Adzuki Beans III. The Water Uptake of Seeds and Hardseededness. Japanese Journal of Crop Science 1995, 64, 713, doi:10.1626/jcs.64.7.

226. Koura, K.; Ouidoh, P.; Azokpota, P.; Ganglo, J.C.; Hounhouigan, D.J. Caractérisation Physique et Composition Chimique Des Graines de Parkia Biglobosa (Jacq.) R. Br. En Usage Au Nord-Bénin. Journal of Applied Biosciences 2014, 75, 6239-6249, doi:10.4314/jab.v75i1.4.

227. Gernah, D.I.; Atolagbe, M.O.; Echegwo, C.C. Nutritional Composition of the African Locust Bean ( Parkia Biglobosa ) Fruit Pulp. NIgerian Food Journal 2007, 25, 190-196.

228. Abdulrahman, B.O.; Osibemhe, M.; Idoko, A.S. The Status of Mineral and Anti-Nutritional Composition of Raw and Fermented Seeds of African Locust Bean (Parkia Biglobosa). nternational Journal of Current Research in Biosciences and Plant Biology 2016, 3, 1-4, doi:http://dx.doi.org/10.20546/ijcrbp.2016.302.001.

229. Enujiugha, V.N.; Ayodele-Oni, O. Evaluation of Nutrients and Some Anti-Nutrients in Lesser-Known, Underutilized Oilseeds. International Journal of Food Science E Technology 2003, 38, 525-528, doi:10.1046/j.13652621.2003.00698.x.

230. Ifesan, B.O.T.; Akintade, A.O.; Gabriel-Ajobiewe, R.A.O. Physicochemical and Nutritional Properties of Mucuna Pruriens and Parkia Biglobosa Subjected to Controlled Fermentation. International Food Research Journal 2017, 24, 2177-2184.

231. Ikhuoria, E.U.; Aiwonegbe, A.E.; Okoli, P.; Idu, M. Characteristics and Composition of African Oil Bean Seed (Pentaclethra Macrophylla Benth). J. App. Sci. 2008, 8, 1337-1339, doi:10.3923/jas.2008.1337.1339.

232. Adeyeye, E.I.; Oshodi, A.A.; Ipinmoroti, K.O. Functional Properties of Some Varieties of African Yam Bean (Sphenostylis Stenocarpa) Flour II. International Journal of Food Sciences and Nutrition 1994, 45, 115-126, doi:10.3109/09637489409166150.

233. Ajayi, F.T.; Akande, S.R.; Odejide, J.O.; Idowu, B. Nutritive Evaluation of Some Tropical Under-Utilized Grain Legume Seeds for Ruminant's Nutrition. 2010, 7.

234. Leung, W.; Busson, F.; Jardin, C. Food Composition Table for Use in Africa; FAO: Rome, Italy, 1968;

235. Ijarotimi, S.; Ruth Esho, T. Comparison of Nutritional Composition and Anti-Nutrient Status of Fermented, Germinated and Roasted Bambara Groundnut Seeds (Vigna Subterranea). British Food Journal - BR FOOD J 2009, 111, 376-386, doi:10.1108/00070700910951515.

236. Akubuo, C.O.; Uguru, M.I. Studies on the Nutritive Characteristics and Fracture Resistance to Compressive Loading of Selected Bambara Groundnut Lines. Journal of the Science of Food and Agriculture 1999, 79, 2063-2066, doi:10.1002/(SICI)1097-0010(199912)79:15<2063::AID-JSFA475>3.0.CO;2-V.

237. Amarteifio, J.O.; Karikari, S.K.; Modise, O.J. The Proximate and Mineral Composition of Six Landraces of Bambara Groundnut. Tropical Science 2002, 42, 188-191.

238. Azman Halimi, R.; Barkla, B.J.; Mayes, S.; King, G.J. The Potential of the Underutilized Pulse Bambara Groundnut (Vigna Subterranea (L.) Verdc.) for Nutritional Food Security. Journal of Food Composition and Analysis 2019, 77, 47-59, doi:10.1016/j.jfca.2018.12.008.

239. Iyayi, E.A.; Kluth, H.; Rodehutscord, M. Chemical Composition, Antinutritional Constituents, Precaecal Crude Protein and Amino Acid Digestibility in Three Unconventional Tropical Legumes in Broilers. Journal of the Science of Food and Agriculture 2006, 86, 2166-2171, doi:10.1002/jsfa.2592.

240. Baptista, A.; Pinho, O.; Pinto, E.; Casal, S.; Mota, C.; Ferreira, I.M.P.L.V.O. Characterization of Protein and Fat Composition of Seeds from Common Beans (Phaseolus Vulgaris L.), Cowpea (Vigna Unguiculata L. Walp) and Bambara Groundnuts (Vigna Subterranea L. Verdc) from Mozambique. Journal of Food Measurement and Characterization 2017, 11, 442-450, doi:10.1007/s11694-016-9412-2. 
241. da Silva, D.O.M.; Santos, C.A.F.; Boiteux, L.S. Adaptability and Stability Parameters of Total Seed Yield and Protein Content in Cowpea (Vigna Unguiculata) Genotypes Subjected to Semi-Arid Conditions. Australian Journal of Crop Science 2016, 10, 1164-1169, doi:10.21475/ajcs.2016.10.08.p7828.

242. Berger, J.; Siddique, K.; Loss, S. Cool Season Grain Legumes for Mediterranean Environments: Species $x$ Environment Interaction in Seed Quality Traits and Anti-Nutritional Factors in the Genus Vicia. Australian Journal of Agricultural Research 1999, 50, 389-401, doi:10.1071/A98098.

243. Bakoglu, A.; Bagci, E.; Ciftci, H. Fatty Acids, Protein Contents and Metal Composition of Some Feed Crops from Turkey. Journal of Food, Agriculture and Environment 2009, 7, 343-346.

244. Martín-Pedrosa, M.; Varela, A.; Guillamon, E.; Cabellos, B.; Burbano, C.; Gomez-Fernandez, J.; De Mercado, E.; Gomez-Izquierdo, E.; Cuadrado, C.; Muzquiz, M. Biochemical Characterization of Legume Seeds as Ingredients in Animal Feed. Spanish Journal of Agricultural Research 2016, 14, doi:10.5424/sjar/2016141-7450.

245. Sadeghi, G.H.; Mohammadi, L.; Ibrahim, S.A.; Gruber, K.J. Use of Bitter Vetch (Vicia Ervilia) as a Feed Ingredient for Poultry. World's Poultry Science Journal 2009, 65, 51-64, doi:10.1017/S0043933909000004.

246. Pastor-Cavada, E.; Juan, R.; Díaz, J.; Alaiz, M.; Vioque, J. Nutritional Characteristics of Seed Proteins in 28 Vicia Species (Fabaceae) from Southern Spain. Journal of food science 2011, 76, C1118-24, doi:10.1111/j.17503841.2011.02336.x.

247. Wani, S.A.; Kumar, P. Fenugreek: A Review on Its Nutraceutical Properties and Utilization in Various Food Products. Journal of the Saudi Society of Agricultural Sciences 2018, 17, 97-106, doi:10.1016/j.jssas.2016.01.007.

248. Abou-Shleel, S. Effect of Air Temperature on Growth, Yield and Active Ingredients of Fenugreek (Trigonella Foenum-Graecum). Nature and Science 2014, 12, 50-54.

249. Hanbury, C.D.; White, C.L.; Mullan, B.P.; Siddique, K.H.M. A Review of the Potential of Lathyrus Sativus L. and L. Cicera L. Grain for Use as Animal Feed. Animal Feed Science and Technology 2000, 87, 1-27, doi:10.1016/S03778401(00)00186-3.

250. Folarin, O.M.; Igbon, O.C. Chemical Composition of Enterolobium Cyclocarpum (Jacq.) Griseb. Seed and Physicochemical Properties of the Oil Extract. Hamdard Medicus 2010, 53, 21-26.

251. Ravindran, R.; Sundar, S.T.B. Nutritive Value of Horse Gram (Dolichos Biflorus) for Egg Type Chicks and Growers. Tamilnadu Journal of Veterinary and Animal Sciences 2009, 5, 125-131.

252. Bhartiya, A.; Aditya, J.P.; Kant, L. Nutritional and Remedial Potential of an Underutilized Food Legume Horsegram (Macrotyloma Uniflorum): A Review. Journal of Animal and Plant Sciences 2015, 25, 908-920.

253. Prasad, S.K.; Singh, M.K. Horse Gram- an Underutilized Nutraceutical Pulse Crop: A Review. Journal of Food Science and Technology 2015, 52, 2489-2499, doi:10.1007/s13197-014-1312-z.

254. Kalidass, C.; Mohan, V. Nutritional and Antinutritional Composition of Itching Bean (Mucuna Pruriens (L.) DC Var. Pruriens): An Underutilized Tribal Pulse in Western Ghats, Tamil Nadu. Tropical and subtropical agroecosystem 2011, 14, 279-293.

255. Adebowale, Y.A.; Adeyemi, I.A.; Oshodi, A.A. Functional and Physicochemical Properties of Flours of Six Mucuna Species. African Journal of Biotechnology 2005, 4, 1461-1468.

256. Abitogun, A. Nutritional Evaluation of Seed and Characterization of Crude Jack Bean (Canavalia Ensiformis) OIL. IOSR Journal of Applied Chemistry 2012, 1, 36-40, doi:10.9790/5736-0163640.

257. Agbede, J.O. Characterisation of the Leaf Meals, Protein Concentrates and Residues from Some Tropical Leguminous Plants. Journal of the Science of Food and Agriculture 2006, 86, 1292-1297, doi:10.1002/jsfa.2491.

258. Salam, J.; Singh, P.K.; Dutta, B.K.; Sahoo, U. Chemical Composition and Nutritive Indices in Parkia Roxburghii g. Don, a Leguminous Plant of India. Indian Journal of Agricultural Biochemistry 2009, 22, 87-93. 
259. Longvah, T.; Deosthale, Y.G. Nutrient Composition and Food Potential of Parkia Roxburghii, a Less Known Tree Legume from Northeast India. Food Chemistry 1998, 62, 477-481, doi:10.1016/S0308-8146(97)00179-9.

260. Blair, M.W.; Porch, T.; Cichy, K.; Galeano, C.H.; Lariguet, P.; Pankhurst, C.; Broughton, W. Induced Mutants in Common Bean (Phaseolus Vulgaris), and Their Potential Use in Nutrition Quality Breeding and Gene Discovery. Israel Journal of Plant Sciences 2007, 55, 191-200, doi:10.1560/IJPS.55.2.191.

261. Gwanzura, T.; Ngambi, J.W.; Norris, D. Nutrient Composition and Tannin Contents of Forage Sorghum, Cowpea, Lablab and Mucuna Hays Grown in Limpopo Province of South Africa. Asian Journal of Animal Sciences 2012, 6, 256-262, doi:10.3923/ajas.2012.256.262.

262. Bhardwaj, H.L.; Hamama, A.A. Genotype and Environment Effects on Lablab Seed Yield and Composition. HortScience 2019, 54, 2156-2158, doi:10.21273/HORTSCI14469-19.

263. Powell, A.M. Marama Bean (Tylosema Esculentum, Fabaceae) Seed Crop in Texas. Econ Bot 1987, 41, 216-220, doi:10.1007/BF02858969.

264. Holse, M.; Husted, S.; Hansen, Å. Chemical Composition of Marama Bean (Tylosema Esculentum) - A Wild African Bean with Unexploited Potential. Journal of Food Composition and Analysis 2010, 23, 648-657, doi:10.1016/j.jfca.2010.03.006.

265. Amarteifio, J.O.; Moholo, D. The Chemical Composition of Four Legumes Consumed in Botswana. Journal of Food Composition and Analysis 1998, 11, 329-332, doi:10.1006/jfca.1998.0595.

266. Gunathilake, K.G.T.; Herath, T.; Wansapala, J. Comparison of Physicochemical Properties of Selected Locally Available Legumes Varieties (Mung Bean, Cowpea and Soybean). Potravinarstvo 2016, 10, 424-430, doi:10.5219/631.

267. Hadjipanayiotou, M.; Economides, S. Chemical Composition, in Situ Degradability and Amino Acid Composition of Protein Supplements Fed to Livestock and Poultry in Cyprus. Livestock Research for Rural Development 2001, 13.

268. Brand, T.; A Brandt, D.; Cruywagen, C. Chemical Composition, True Metabolisable Energy Content and Amino Acid Availability of Grain Legumes for Poultry. South African Journal of Animal Science 2004, 34, doi:10.4314/sajas.v34i2.3815.

269. Anton, A.A.; Ross, K.A.; Beta, T.; Gary Fulcher, R.; Arntfield, S.D. Effect of Pre-Dehulling Treatments on Some Nutritional and Physical Properties of Navy and Pinto Beans (Phaseolus Vulgaris L.). LWT - Food Science and Technology 2008, 41, 771-778, doi:10.1016/j.lwt.2007.05.014.

270. Grosso, N.R.; Nepote, V.; Guzmán, C.A. Chemical Composition of Some Wild Peanut Species (Arachis L.) Seeds. J. Agric. Food Chem. 2000, 48, 806-809, doi:10.1021/jf9901744.

271. Fathima, K.R.; Mohan, V. Nutritional and Antinutritional Assessment of Mucuna Atropurpurea DC: An Underutilized Tribal Pulse. African Journal of Basic E Applied Sciences 2009, 129-136.

272. Siddhuraju, P.; Vijayakumari, K.; Janardhanan, K. The Biochemical Composition and Nutritional Potential of the Tribal Pulse, Alysicarpus Rugosus (Willd.) DC. Food Chemistry 1992, 45, 251-255, doi:10.1016/0308-8146(92)90156V.

273. Kallah, Muh.S.; Bale, J.O.; Abdullahi, U.S.; Muhammad, I.R.; Lawal, R. Nutrient Composition of Native Forbs of Semi-Arid and Dry Sub-Humid Savannas of Nigeria. Animal Feed Science and Technology 2000, 84, 137-145, doi:10.1016/S0377-8401(99)00131-5.

274. Hoque Bepary, R.; Wadikar, D.D.; Patki, P.E. Rice Bean: Nutritional Vibrant Bean of Himalayan Belt (North East India). Nutrition and Food Science 2016, 46, 412-431, doi:10.1108/NFS-08-2015-0097.

275. Nigussie, Z.; Alemayehu, G. Sesbania Sesban (L.) Merrill: Potential Uses of an Underutilized Multipurpose Tree in Ethiopia. African Journal of Plant Science 2013, 7, 468-475, doi:0.5897/AJPS2012.0716. 
276. Rubatzky, V.E.; Yamaguchi, M. World Vegetables: Principles, Production, and Nutritive Values; 2nd ed.; Springer US, 1997; ISBN 978-1-4613-7756-6.

277. Bhat, R.; Karim, A.A. Exploring the Nutritional Potential of Wild and Underutilized Legumes. Comprehensive Reviews in Food Science and Food Safety 2009, 8, 305-331, doi:10.1111/j.1541-4337.2009.00084.x.

278. Ajayi, I.A.; Oderinde, R.A.; Kajogbola, D.O.; Uponi, J.I. Oil Content and Fatty Acid Composition of Some Underutilized Legumes from Nigeria. Food Chemistry 2006, 99, 115-120, doi:10.1016/j.foodchem.2005.06.045.

279. Grollier, C.; Debien, C.; Dornier, M.; Reynes, M. Principales Caractéristiques et Voies de Valorisation Du Tamarin. Fruits 1998, 53, 271-280.

280. Van der Stege, C.; Prehsler, S.; Hartl, A.; Vogl, C.R. Tamarind (Tamarindus Indica L.) in the Traditional West African Diet: Not Just a Famine Food. Fruits 2011, 66, 171-185, doi:10.1051/fruits/2011025.

281. Gulisano, A.; Alves, S.; Martins, J.N.; Trindade, L.M. Genetics and Breeding of Lupinus Mutabilis: An Emerging Protein Crop. Frontiers in Plant Science 2019, 10, 1385, doi:10.3389/fpls.2019.01385.

282. Porch, T.G.; Cichy, K.; Wang, W.; Brick, M.; Beaver, J.S.; Santana-Morant, D.; Grusak, M.A. Nutritional Composition and Cooking Characteristics of Tepary Bean (Phaseolus Acutifolius Gray) in Comparison with Common Bean (Phaseolus Vulgaris L.). Genetic Resources and Crop Evolution 2017, 64, 935-953, doi:10.1007/s10722016-0413-0.

283. Vadivel, V.; Janardhanan, K. Nutritional and Anti-Nutritional Composition of Velvet Bean: An under-Utilized Food Legume in South India. Int J Food Sci Nutr 2000, 51, 279-287.

284. Amoo, I.A.; Atasie, V.N.; Kolawole, O.O. Proximate Composition, Nutritionally Valuable Minerals, Protein Functional Properties and Anti-Nutrient Contents of Mucuna Preta, Mucuna Ghana and Mucuna Veracruz Mottle. Pakistan Journal of Nutrition 2009, 8, 1204-1208, doi:10.3923/pjn.2009.1204.1208.

285. Anugroho, F.; Kitou, M.; Kinjo, K.; Kobashigawa, N. Growth and Nutrient Accumulation of Winged Bean and Velvet Bean as Cover Crops in a Subtropical Region. Plant Production Science 2010, 13, 360-366, doi:10.1626/pps.13.360.

286. Arivalagan, M.; Prasad, T.V.; Singh, H.; Kumar, A. Variability in Biochemical and Mineral Composition of Mucuna Pruriens (L.) DC. - An Underutilized Tropical Legume. Legume Research 2014, 37, 483-491, doi:10.5958/0976-0571.2014.00664.X.

287. Balogun, I.O.; Olatidoye, O.P. Chemical Composition and Nutritional Evaluation of Velvet Bean Seeds (Mucuna Utilis) for Domestic Consumption and Industrial Utilization in Nigeria. Pakistan Journal of Nutrition 2012, 11, 116122, doi:10.3923/pjn.2012.116.122.

288. Bhat, R.; Sridhar, K.R.; Young, C.-C.; Bhagwath, A.A.; Ganesh, S. Composition and Functional Properties of Raw and Electron Beam-Irradiated Mucuna Pruriens Seeds. International Journal of Food Science and Technology 2008, 43, 1338-1351, doi:10.1111/j.1365-2621.2007.01617.x.

289. Chikagwa-Malunga, S.K.; Adesogan, A.T.; Sollenberger, L.E.; Badinga, L.K.; Szabo, N.J.; Littell, R.C. Nutritional Characterization of Mucuna Pruriens. 1. Effect of Maturity on the Nutritional Quality of Botanical Fractions and the Whole Plant. Animal Feed Science and Technology 2009, 148, 34-50, doi:10.1016/j.anifeedsci.2008.03.004.

290. Noman, A.S.M.; Hoque, M.A.; Haque, M.M.; Pervin, F.; Karim, M.R. Nutritional and Anti-Nutritional Components in Pachyrhizus Erosus L. Tuber. Food Chemistry 2007, 102, 1112-1118, doi:10.1016/j.foodchem.2006.06.055.

291. Aremu, C.; Ige, S.; Ibirinde, O.; Raji, I.A.; Abolusoro, S.; Ajiboye, B.; Obaniyi, S.; Adekiya, A.; Asaleye, A. Assessing Yield Stability in African Yam Bean (Sphenostylis Stenocarpa) Performance Using Year Effect. Open Agriculture 2020, 5, 202-212, doi:10.1515/opag-2020-0020. 
292. Skylas, D.J.; Paull, J.G.; Hughes, D.G.D.; Gogel, B.; Long, H.; Williams, B.; Mundree, S.; Blanchard, C.L.; Quail, K.J. Nutritional and Anti-Nutritional Seed-Quality Traits of Faba Bean (Vicia Faba) Grown in South Australia. Crop and Pasture Science 2019, 70, 463-472, doi:10.1071/CP19017.

293. Wood, J.A.; Tan, H.-T.; Collins, H.M.; Yap, K.; Khor, S.F.; Lim, W.L.; Xing, X.; Bulone, V.; Burton, R.A.; Fincher, G.B.; et al. Genetic and Environmental Factors Contribute to Variation in Cell Wall Composition in Mature Desi Chickpea (Cicer Arietinum L.) Cotyledons. Plant Cell and Environment 2018, 41, 2195-2208, doi:10.1111/pce.13196.

294. Wood, J.A.; Knights, E.J.; Campbell, G.M.; Choct, M. Differences between Easy- and Difficult-to-Mill Chickpea (Cicer Arietinum L.) Genotypes. Part II: Protein, Lipid and Mineral Composition. Journal of the Science of Food and Agriculture 2014, 94, 1446-1453, doi:10.1002/jsfa.6436.

295. Wood, J.A.; Knights, E.J.; Campbell, G.M.; Choct, M. Differences between Easy- and Difficult-to-Mill Chickpea (Cicer Arietinum L.) Genotypes. Part III: Free Sugar and Non-Starch Polysaccharide Composition. Journal of the Science of Food and Agriculture 2014, 94, 1454-1462, doi:10.1002/jsfa.6445.

296. Celmeli, T.; Sarı, H.; Canci, H.; SARI, D.; Adak, A.; Eker, T.; Toker, C. The Nutritional Content of Common Bean (Phaseolus Vulgaris L.) Landraces in Comparison to Modern Varieties. Agronomy 2018, 8, 166, doi:10.3390/agronomy8090166.

297. Paredes, M.; Becerra, V.V.; Tay, J.U. Inorganic Nutritional Composition of Common Bean (Phaseolus Vulgaris L.) Genotypes Race Chile. Chilean Journal of Agricultural Research 2009, 69, 486-495, doi:http://dx.doi.org/10.4067/S0718-58392009000400002.

298. Batista, K.A.; Prudêncio, S.H.; Fernandes, K.F. Changes in the Functional Properties and Antinutritional Factors of Extruded Hard-to-Cook Common Beans (Phaseolus Vulgaris, L.). Journal of Food Science 2010, 75, C286-C290, doi:10.1111/j.1750-3841.2010.01557.x.

299. Thavarajah, D.; Thavarajah, P.; Sarker, A.; Materne, M.; Vandemark, G.; Shrestha, R.; Idrissi, O.; Hacikamiloglu, O.; Bucak, B.; Vandenberg, A. A Global Survey of Effects of Genotype and Environment on Selenium Concentration in Lentils (Lens Culinaris L.): Implications for Nutritional Fortification Strategies. Food Chemistry 2011, 125, 72-76, doi:10.1016/j.foodchem.2010.08.038.

300. Thavarajah, D.; Thavarajah, P.; See, C.-T.; Vandenberg, A. Phytic Acid and Fe and Zn Concentration in Lentil (Lens Culinaris L.) Seeds Is Influenced by Temperature during Seed Filling Period. Food Chemistry 2010, 122, 254259, doi:10.1016/j.foodchem.2010.02.073.

301. Summerfield, R.J.; Muehlbauer, F.J. Mineral Nutrient Composition of Lentil Seeds. Communications in Soil Science and Plant Analysis 1982, 13, 317-333, doi:10.1080/00103628209367271.

302. Sujak, A.; Kotlarz, A.; Strobel, W. Compositional and Nutritional Evaluation of Several Lupin Seeds. Food Chemistry 2006, 98, 711-719, doi:10.1016/j.foodchem.2005.06.036.

303. Uhunmwangho, E.S.; Omoregie, E.S. Evaluation of Nutritive, Antinutritive and Mineral Content of Tetracarpidium Conophorum (African Walnut) Seed Oil at Different Stages of Fruit Maturation. 210Haya: The Saudi Journal of Life Sciences 2017, 2, 210-216.

304. Ayodeji, A.E.; Aliyu, N. Tetracarpidium Conophorum (African Walnut) Hutch. \& Dalziel: Ethnomedicinal Uses and Its Therapeutic Activities. Journal of Medicinal Plants for Economic Development; Vol 2, No 1 (2018)DO 10.4102/jomped.v2i1.47 2018.

305. Nergiz, C.; Yalcin, H.; Yildiz, H. Some Analytical Characters of Cottonseed Varieties Grown In Turkey. Grasas y Aceites 1997, 411-414.

306. Renuka, C.K.; Kumarmath, P.S.; Kadakol, J.C.; Hosamani, S.V. Chemical Composition and Antinutritional Factors in Different Parts and Whole Cotton (Gossypium Hirsutum) Plant. Karnataka Journal of Agricultural Sciences 2005, 18, 114-117. 
307. Bellaloui, N.; Turley, R.B.; Stetina, S.R. Cottonseed Protein, Oil, and Minerals in Cotton (Gossypium Hirsutum L.) Lines Differing in Curly Leaf Morphology. Plants 2021, 10, doi:10.3390/plants10030525.

308. Akobundu, E.N.T.; Cherry, J.P.; Simmons, J.G. Chemical, Functional, and Nutritional Properties of Egusi (Colocynthis Citrullus L.) Seed Protein Products. Journal of Food Science 1982, 47, 829-835, doi:10.1111/j.13652621.1982.tb12725.x.

309. Souci, S.W.; Fachmann, W.; Kraut, H. Food Composition and Nutrition Tables; Medpharm Gmbh Scientific Pub: Boca Raton, 2008; ISBN 978-3-8047-5038-8.

310. Bell, J.; Rakow, G.; Downey, R. Mineral Composition of Oil-Free Seeds of Brassica Napus, B. Rapa and B. Juncea as Affected by Location and Year. Revue canadienne de science animale 1999, 405-408.

311. Lajolo, F.; Marquez, U.; Filisetti-Cozzi, T.; McGregor, D. Chemical Composition and Toxic Compounds in Rapeseed (Brassica Napus, L.) Cultivars Grown in Brazil. Journal of Agricultural and Food Chemistry 1991, 19331937.

312. Reddy, N.R.; Pierson, M.D.; Sathe, S.K.; Salunkhe, D.K. Dry Bean Tannins: A Review of Nutritional Implications. Journal of the American Oil Chemists' Society 1985, 62, 541-549, doi:10.1007/BF02542329.

313. Coulibaly, M.; Kouamé, C.A.; Kouamé, D.Y.; Kouassi, N.K.; Asare Pereko, K.K.; N'guessan Amani, G. Effect of Post-Harvest Traditional Technologies on the Nutrient Content and Antioxidant Compounds of Defatted Flours from Ricinodendron Heudelotti (Baill. Pierre Ex Pax) Seed Kernels. Technologies 2018, 6, 37, doi:10.3390/technologies6020037.

314. Nyananyo, B.L.; Nyingifa, A.L. Phytochemical Investigation on the Seed of Sphenostylis Stenocarpa (Hochst Ex A. Rich.) Harms (Family Fabaceae). Journal of Applied Sciences and Environmental Management 2011, 15, 419-423.

315. Mohan, V.R.; Tresina, P.S.; Daffodil, E.D. Antinutritional Factors in Legume Seeds: Characteristics and Determination. In Encyclopedia of Food and Health; Caballero, B., Finglas, P.M., Toldrá, F., Eds.; Academic Press: Oxford, 2016; pp. 211-220 ISBN 978-0-12-384953-3.

316. Okafor, J.; Ani, J.; Okafor, G. Effect of Processing Methods on Qualities of Bambara Groundnut (Voandzeia Subterranea (L.) Thouars) Flour and Their Acceptability in Extruded Snacks. American Journal of Food Technology 2014, 350-359, doi:10.3923/ajft.2014.350.359.

317. Unigwe, A.E.; Doria, E.; Adebola, P.; Gerrano, A.S.; Pillay, M. Anti-Nutrient Analysis of 30 Bambara Groundnut (Vigna Subterranea) Accessions in South Africa. Journal of Crop Improvement 2018, 32, 208-224, doi:10.1080/15427528.2017.1405857.

318. Camelo, S.; Torres, V.; Diaz, M.F. Multivariate Analysis of the Anti-Nutritional Factors of the Seasonal Legumes Grains. Cuban Journal of Agricultural Science 2008, 42, 339-341.

319. Francoa, O.L.; Dos Santos, R.C.; Batista, J.A.N.; Mendes, A.C.M.; De Araújo, M.A.M.; Monnerat, R.G.; Fátima Grossi-de-Sá, M.; De Freitas, S.M. Effects of Black-Eyed Pea Trypsin/Chymotrypsin Inhibitor on Proteolytic Activity and on Development of Anthonomus Grandis. Phytochemistry 2003, 63, 343-349, doi:10.1016/S00319422(03)00108-0.

320. Grela, E.; Studziñski, T.; Matras, J. Antinutritional Factors in Seeds of Lathyrus Sativus Cultivated in Poland. Lathyrus Lathyrism Newsletter 2001, 101-104.

321. Campbell, C.G. Grass Pea: Lathyrus Sativus L; Promoting the conservation and use of underutilized and neglected crops; IPGRI: Rome, 1997; ISBN 978-92-9043-341-5.

322. Girma, D.; Korbu, L. Genetic Improvement of Grass Pea (Lathyrus Sativus) in Ethiopia: An Unfulfilled Promise. Plant Breeding 2012, 131, 231-236, doi:10.1111/j.1439-0523.2011.01935.x.

323. Lambein, F.; Travella, S.; Kuo, Y.-H.; Van Montagu, M.; Heijde, M. Grass Pea (Lathyrus Sativus L.): Orphan Crop, Nutraceutical or Just Plain Food? Planta 2019, 250, 821-838, doi:10.1007/s00425-018-03084-0. 
324. Abiola, C.; Oyetayo, O. Proximate and Anti-Nutrient Contents of Kersting's Groundnut (Macrotyloma Geocarpum) Subjected to Different Fermentation Methods. British Microbiology Research Journal 2015, 10, 1-10, doi:10.9734/BMRJ/2015/19735.

325. Betancur-Ancona, D.; Gallegos-Tintoré, S.; Delgado-Herrera, A.; Pérez-Flores, V.; Ruelas, A.C.; Chel-Guerrero, L. Some Physicochemical and Antinutritional Properties of Raw Flours and Protein Isolates from Mucuna Pruriens (Velvet Bean) and Canavalia Ensiformis (Jack Bean). International Journal of Food Science E Technology 2008, 43, 816-823, doi:10.1111/j.1365-2621.2007.01521.x.

326. Laurena, A.C.; Revilleza, M.J.R.; Mendoza, E.M.T. Polyphenols, Phytate, Cyanogenic Glycosides, and Trypsin Inhibitor Activity of Several Philippine Indigenous Food Legumes. Journal of Food Composition and Analysis 1994, 7, 194-202, doi:10.1006/jfca.1994.1019.

327. Emire, S.; Rakshit, S. Effect of Processing on Antinutrients and in Vitro Protein Digestibility of Kidney Bean (Phaseolus Vulgaris L.) Varieties Grown in East Africa. Food Chemistry - FOOD CHEM 2007, 103, 161-172, doi:10.1016/j.foodchem.2006.08.005.

328. Drew, M.D.; Borgeson, T.L.; Thiessen, D.L. A Review of Processing of Feed Ingredients to Enhance Diet Digestibility in Finfish. Animal Feed Science and Technology 2007, 138, 118-136, doi:10.1016/j.anifeedsci.2007.06.019.

329. Nyembwe, P.; Minnaar, A.; Duodu, K.G.; de Kock, H.L. Sensory and Physicochemical Analyses of Roasted Marama Beans [Tylosema Esculentum (Burchell) A. Schreiber] with Specific Focus on Compounds That May Contribute to Bitterness. Food Chem 2015, 178, 45-51, doi:10.1016/j.foodchem.2015.01.070.

330. Mubarak, A.E. Nutritional Composition and Antinutritional Factors of Mung Bean Seeds (Phaseolus Aureus) as Affected by Some Home Traditional Processes. Food Chemistry 2005, 89, 489-495, doi:10.1016/j.foodchem.2004.01.007.

331. Berger, J.D.; Robertson, L.D.; Cocks, P.S. Agricultural Potential of Mediterranean Grain and Forage Legumes: 2) Anti-Nutritional Factor Concentrations in the Genus Vicia. Genetic Resources and Crop Evolution 2003, 50, 201-212, doi:10.1023/A:1022954232533.

332. Lolas, G.M.; Markakis, P. The Phytase of Navy Beans (Phaseolus Vulgaris). Journal of Food Science 1977, 42, 10941097, doi:10.1111/j.1365-2621.1977.tb12674.x.

333. Richardson, J. The Effects of Pretreatment Conditions and Micronization on the Anti-Nutritional Factors, Cookability, and Microorganisms in Navy Beans (Phaseolus Vulgaris L.)., University of Manitoba: Winnipeg, Manitoba, 2003.

334. Kelkar, S.; Siddiq, M.; Harte, J.; Dolan, K.; Nyombaire, G.; Suniaga, H. Use of Low-Temperature Extrusion for Reducing Phytohemagglutinin Activity (PHA) and Oligosaccharides in Beans (Phaseolus Vulgaris L.) Cv. Navy and Pinto. 2012; 133: 1636-1639. Food Chemistry 2012, 1636-1639.

335. Saxena, K.B.; Kumar, R.V.; Sultana, R. Quality Nutrition through Pigeonpea-a Review. Health 2010, 02, 1335, doi:10.4236/health.2010.211199.

336. Kaur, D.; Kapoor, A.C. Nutrient Composition and Antinutritional Factors of Rice Bean (Vigna Umbellata). Food Chemistry 1992, 43, 119-124, doi:10.1016/0308-8146(92)90224-P.

337. Hory, H.; Weder, J.; Belitz, H. Vergleichende Untersuchungen Der Trypsinspezifischen Reaktiven Zentren Verschiedener Phaseolus Coccineus- Und Phaseolus Vulgaris-Inhibitoren. Zeitschrift für LebensmittelUntersuchung und Forschung 1985, 341-347.

338. Morgan, M.R.; Manen, J.F. Lectin Variability in Phaseolus Coccineus. Phytochemistry 1985, 24, 1981-1985, doi:10.1016/S0031-9422(00)83105-2. 
339. Vadivel, V.; Janardhanan, K. The Nutritional and Antinutritional Attributes of Sword Bean (Canavalia Gladiata (Jacq.) DC.): An under-Utilized Tribal Pulse from South India. International Journal of Food Science E Technology 2004, 39, 917-926, doi:10.1111/j.1365-2621.2004.00851.x.

340. De Caluw, E.; Halamov, K.; Van Damme, P. Tamarindus Indica L.: A Review of Traditional Uses, Phytochemistry and Pharmacology. Afrika Focus 2010, 23, 53-53.

341. Suneja, Y.; Kaur, S.; Gupta, A.K.; Kaur, N. Levels of Nutritional Constituents and Antinutritional Factors in Black Gram (Vigna Mungo L. Hepper). Food Research International 2011, 44, 621-628, doi:10.1016/j.foodres.2010.12.020.

342. Misra, L.; Wagner, H. Alkaloidal Constituents of Mucuna Pruriens Seeds. Phytochemistry 2004, 65, 2565-2567, doi:10.1016/j.phytochem.2004.08.045.

343. Adepoju, G.K.A.; Odubena, O.O. Effect of Mucuna Pruriens on Some Haematological and Biochemical Parameters. Journal of Medicinal Plants Research 2009, 3, 073-076.

344. Gurumoorthi, P.; Janardhanan, K.; Kalavathy, G. Improving Nutritional Value of Velvet Bean, Mucuna Pruriens (L.) DC. Var. Utilis (Wall.Ex.Wight) L. H. Bailey, an under-Utilized Pulse, Using Microwave Technology. Indian Journal of Traditional Knowledge 2013, 12, 677-681.

345. Varga, E.; Varga, M. Development and Validation of an LC-MS/MS Method for the Analysis of L-DOPA in Oat. Acta Biologica Szegediensis 2014, 58, 133-137.

346. Chandrashekharaiah, K.S. Studies on Proteinase Inhibitors from the Seeds of Mucuna Utilis. Research Journal of Chemistry and Environment 2018, 22, 23-27.

347. Kotaru, M.; Ikeuchi, T.; Yoshikawa, H.; Ibuki, F. Investigations of Antinutritional Factors of the Winged Bean (Psophocarpus Tetragonolobus). Food Chemistry 1987, 24, 279-286, doi:10.1016/0308-8146(87)90103-8.

348. Shet, M.S.; Madaiah, M. Distribution of Lectin Activity at Different Stages in the Tissues of Winged Bean (Psophocarpus Tetragonolobus (L.) DC). Plant Science 1987, 53, 161-165, doi:10.1016/0168-9452(87)90126-9.

349. Topal, N.; Bozoğlu, H. Determination of L-Dopa (L-3, 4-Dihydroxyphenylalanine) Content of Some Faba Bean (Vicia Faba L.) Genotypes. Tarim Bilimleri Dergisi 2016, 22, 145-151.

350. el-Adawy, T.A. Nutritional Composition and Antinutritional Factors of Chickpeas (Cicer Arietinum L.) Undergoing Different Cooking Methods and Germination. Plant Foods Hum Nutr 2002, 57, 83-97.

351. Sathe, S.K.; Deshpande, S.S.; Reddy, N.R.; Goll, D.E.; Salunkhe, D.K. Effects of Germination on Proteins, Raffinose Oligosaccharides, and Antinutritional Factors in the Great Northern Beans (Phaseolus Vulgaris L.). Journal of Food Science 1983, 48, 1796-1800, doi:10.1111/j.1365-2621.1983.tb05087.x.

352. Savage, G.; Deo, S. The Nutritional Value of Peas (Pisum Sariurn). A Literature Review. Nutrition Abstracts and Reviews Series A 1989, 65-87.

353. Hefnawy, T.H. Effect of Processing Methods on Nutritional Composition and Anti-Nutritional Factors in Lentils (Lens Culinaris). Annals of Agricultural Sciences 2011, 56, 57-61, doi:10.1016/j.aoas.2011.07.001.

354. Thavarajah, P.; Thavarajah, D.; Vandenberg, A. Low Phytic Acid Lentils (Lens Culinaris L.): A Potential Solution for Increased Micronutrient Bioavailability. Journal of Agricultural and Food Chemistry 2009, 57, 9044-9049, doi:10.1021/jf901636p.

355. Getachew, P.; Umeta, M.; Retta, N.; Bekele, T.; Haki, G.D. Proximate Composition and Anti-Nutritional Factors of Traditionally Processed White Lupine (Lupinus Qlbus L.) Fabaceae, Grown in Ethiopia. Ethiopian Journal of Biological Sciences 2012, 11, 133-146.

356. Nigussie, Z. Contribution of White Lupin (Lupinus Albus L.) for Food Security in North-Western Ethiopia: A Review. Asian Journal of Plant Sciences 2012, 200-205. 
357. Jansen, G.; Jürgens, H. -U; Ordon, F. Effects of Temperature on the Alkaloid Content of Seeds of Lupinus Angustifolius Cultivars. Journal of Agronomy and Crop Science 2009, 195, 172-177, doi:10.1111/j.1439037X.2008.00356.x.

358. Boye, J.; Ribéreau, S. Assessing Compositional Differences in Soy Products and Impacts on Health Claims. Soybean and Nutrition 2011, doi:10.5772/17688. 